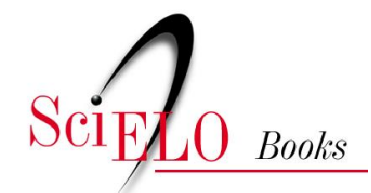

\title{
A extensão universitária em comunicação para a formação da cidadania
}

\author{
Eliza Bachega Casadei (org.)
}

\section{SciELO Books / SciELO Livros / SciELO Libros}

CASADEI, EB., org. A extensão universitária em comunicação para a formação da cidadania [online]. São Paulo: Cultura Acadêmica, 2016, 135 p. ISBN 978-85-7983-746-3. Available from: doi: 10.7476/9788579837463. Also available in ePUB from:

http://books.scielo.org/id/zhy4d/epub/casadei-9788579837463.epub.

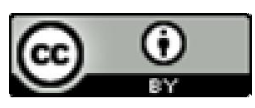

All the contents of this work, except where otherwise noted, is licensed under a Creative Commons Attribution 4.0 International license.

Todo o conteúdo deste trabalho, exceto quando houver ressalva, é publicado sob a licença Creative Commons Atribição 4.0.

Todo el contenido de esta obra, excepto donde se indique lo contrario, está bajo licencia de la licencia Creative Commons Reconocimento 4.0. 


\section{A extensão UNIVERSITÁRIA EM COMUNICAÇÃO PARA A FORMAÇÃO DA CIDADANIA}




$$
\begin{gathered}
\text { Realização } \\
\text { Pró-reitoria de Extensão Universitária (Proex) } \\
\text { Rua Quirino de Andrade, 215 - 10andar } \\
\text { 01049-010 - São Paulo - SP }
\end{gathered}
$$

Dirigentes da Universidade Estadual Paulista "Júlio de Mesquita Filho" http://www.unesp.br/portal\#!/reitoria_ses/dirigentes-da-unesp/

Conselho Editorial da Pró-reitoria de Extensão Universitária

Prof. Dr. Cláudio Cesar de Paiva - FCL/Araraquara

Prof. Dr. Eduardo Galhardo - FCL/Assis

Prof. Dr. José Arnaldo Frutuoso Roveda - ICT/Sorocaba

Profa Dra Márcia Pereira da Silva - FCHS/Franca

Profa Dra Maria Cândida Soares Del Masso - FFC/Marília

Profa Dra Rosane Michelli de Castro - FFC/Marília

Prof. Dr. Sebastião Souza Lemes - FCL/Araraquara

Comissão de Avaliação definida pela Pró-reitoria de Extensão Universitária da Unesp

Profa Dra Ana Paula Cordeiro - FFC/Marília

Prof. Dr. Antônio Cézar Leal - FCT/Presidente Prudente

Profa Dra Camila Pires Cremasco Gabriel - FCE/Tupã

Profa Dra Eliana Marques Zanata - FC/Bauru

Prof. Dr. José Carlos Miguel - FFC/Marília

Profa Dra Luciene Cristina Risso - CE/Ourinhos

Profa Dra Maria do Carmo Kobayashi - FC/Bauru

Prof. Dr. Mário Lázaro Camargo - FC/Bauru

Profa Dra Nanci Soares - FCHS/Franca

Profa Dra Rosa Maria Feiteiro Cavalari - IB/Rio Claro

Profa Dra Tânia da Costa Garcia - FCHS/Franca

Profa Dra Tatiana Schneider Vieira de Moraes - FFC/Marília

Prof. Dr. Victor Hugo de Almeida - FCHS/Franca

Membros da Comissão Permanente de Extensão Universitária - CPEU da

Faculdade de Arquitetura, Artes e Comunicação do Campus de Bauru responsáveis pela indicação da obra

Prof. Dr. Marcelo Carbone Carneiro - Presidente

Prof. Dr. Arlindo Rebechi Junior

Profa Dra Célia Maria Retz Godoy dos Santos

Prof. Dr. Cláudio Roberto y Goya

Prof. Dr. José Xaides de Sampaio Alves

Prof. Dr. Juarez Tadeu de Paula Xavier

Profa Dra Lucinéa Marcelino Vilella

Prof. Dr. Luiz Antonio Vasques Hellmeister

Profa Dra Maria do Carmo Jampaulo Plácido Palhaci

Profa Dra Maria Eugênia Porém

Profa Dra Maria Solange Gurgel de Castro Fontes Profa Dra Suely Maciel

Prof. Dr. Tomas Queiroz Ferreira Barata

Agnes Sofia Guimarães Cruz

Edson Massami Koike

Lucas Arantes Zanetti

Tânea Regina de Antônio 
ELIZA BACHEGA CASADEI (Org.)

\section{A extensão UNIVERSITÁRIA EM COMUNICAÇÃO PARA A FORMAÇÃO DA CIDADANIA}


(C) 2016 Cultura Acadêmica

\section{Cultura Acadêmica}

Praça da Sé, 108

01001-900 - São Paulo - SP

Tel.: (0xx11) 3242-7171

Fax: (0xx11) 3242-7172

www.culturaacademica.com.br

www.livrariaunesp.com.br

feu@editora.unesp.br

CIP - Brasil. Catalogação na publicação

Sindicato Nacional dos Editores de Livros, RJ

\section{EE96}

A extensão universitária em comunicação para a formação da cidadania [recurso eletrônico] / organizadora Eliza Bachega Casadei. - 1.ed.

- São Paulo: Cultura Acadêmica, 2016.

recurso digital

Formato: ebook

Requisitos do sistema:

Modo de acesso: world wide web

ISBN 978-85-7983-746-3 (recurso eletrônico)

1. Educação. 2. Abordagem interdisciplinar do conhecimento.

3. Educação - Estudo e ensino. 4. Extensão universitária. I. Casadei, Eliza Bachega.

Este livro é publicado pelo Programa de Publicações da Pró-Reitoria de Extensão Universitária da Universidade Estadual Paulista "Júlio de Mesquita Filho" (Unesp)

Editora afiliada:

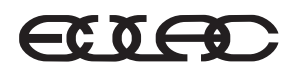

Asociación de Editoriales Universitarias de América Latina y el Caribe

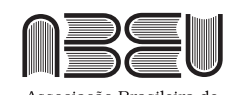

Associação Brasileira de Editoras Universitárias 


\section{SUMÁRIO}

Apresentação 7

1 A extensão universitária e as demandas por justiça: cidadania e comunicação como uma questão de endereçamento 13

Eliza Bachega Casadei

2 "Ser contado como falante": a interação dialógica nas práticas de extensão universitária 31 Mariana Duccini Junqueira da Silva

3 Cultura política, mídia e mobilização 45 Paulo Roberto Figueira Leal, Rafael do Nascimento Grohmann e Rodrigo Souza Silva

4 Mapeamento dos arranjos produtivos locais intensos de cultura: tecnologias sociais para a adoção de políticas públicas inclusivas nas cidades 63 Juarez Tadeu de Paula Xavier

5 Observatório do esporte: extensão e crítica da mídia esportiva na Rádio Unesp FM 79

Marcos Américo, José Carlos Marques, Carlo José Napolitano e Fábio Camargo Fleury de Oliveira 
6 A lógica do pixel e split-screen aplicada na realização da vinheta do "Pau a Pixel: crítica" 93

Letícia Passos Affini e Luis Enrique Cazani Júnior

7 Jornalismo colaborativo: a comunidade na prática jornalística de televisão 101

Francisco Machado Filho e Mayra Fernanda Ferreira

8 Empreendedorismo e formação profissional na extensão: a contribuição da Agência Júnior de Jornalismo da Unesp na visão de seus ex-integrantes 115

Francisco Rolfsen Belda

Sobre os autores 133 


\section{ApREsentAÇÃo}

Eliza Bachega Casadei

A inserção da Extensão Universitária como um dos pilares de sustentação da atividade acadêmica no Brasil resultou de um reposicionamento epistemológico que, ao questionar os métodos tradicionais da produção da ciência e a função social da universidade, valorizou "os contextos de práticas como ponto de partida do conhecimento científico”. Tal disposição estava embasada em uma ideia que "derrubava a tese da neutralidade da ciência e assumia a relação entre os saberes de origens diversas como legítimos e necessários. Reconhecia a dimensão política e cultural do conhecimento e de suas formas de produção" (Cunha, 2012).

Para Cunha (2012), inclusive, trata-se de uma resposta dada tipicamente por países latino-americanos, na tentativa de responder a demandas de sociedades marcadas por fortes desigualdades sociais. Constitui uma diligência em que se exige que "a universidade, em especial a de natureza pública, tenha responsabilidade com o desenvolvimento social equilibrado, produzindo saberes para a melhoria de vida de toda a população” (Cunha, 2012).

Ainda assim, em relação aos outros pilares presentes nas universidades brasileiras, a extensão continua a ocupar uma posição frágil de menor destaque, o que se reflete em menor financiamento de suas práticas e, consequentemente, em menor engajamento dos 
atores envolvidos em sua manutenção, já que ela teria menos prestígio em relação à pesquisa e ao ensino. Além desses problemas fundamentais, é possível notar, ainda, que, "atingida pelas políticas globais das últimas décadas", a extensão "tende, em termos de prestígio, a ser identificada com a prestação de serviços, muitos dos quais realizados com o sentido da captação de recursos, alterando substancialmente sua missão original" (Cunha, 2012).

A esses problemas somam-se outros que estão ligados às formas como a extensão universitária foi entendida e definida ao longo do tempo. Não podemos nos esquecer de que, dentre os problemas enfrentados pela extensão, estão os relacionados "aos poderes de invenção de um discurso sobre o objeto que ele pretende descrever" (Didi-Huberman, 2013, p.115), estes bem mais difíceis e orgânicos. Isso quer dizer que "todo campo de saber se constitui imaginando-se terminado, 'vendo-se' possuir inteiramente a suma do saber que ainda não possui e para o qual se constitui. Ele se constitui, portanto, votando-se a um ideal". O problema encontra-se no fato de que "ao fazer isso, arrisca-se também a votar seu objeto ao ideal em questão: sujeita o objeto a esse ideal, imaginando-o, vendo-o ou prevendo-o - em suma, dando-lhe forma e inventando-o por antecipação" (Didi-Huberman, 2013, p.116).

Em sua ainda breve trajetória nas universidades brasileiras, a extensão universitária teve seu objeto marcado de distintas formas, o que resultou em diferentes metas traçadas, bem como diferentes ideais pregados e discursos norteadores da prática. A extensão universitária, portanto, está sujeita a disputas simbólicas de várias ordens que afetam as atividades e projetos da área, colocando-os em um terreno simbólico em constante disputa. Tais conflitos não se dão apenas no plano teórico, mas influenciam mesmo na disputa por prestígio e verbas dentro da estrutura universitária.

Não bastassem esses entraves, é possível demarcar, ainda, controvérsias específicas da extensão universitária na área da comunicação, que enfrenta suas próprias questões e adversidades. O objetivo do presente livro é justamente debater esses problemas relacionados diretamente aos projetos de extensão na área da 
comunicação social, bem como os possíveis enfrentamentos a eles urdidos por diversas instituições de ensino superior.

O livro pretende reunir textos de pesquisadores que trabalhem a extensão universitária na área da comunicação em suas múltiplas vertentes. A partir de estudos que versem desde aspectos teóricos até experiências práticas, o livro discutirá temas como a importância da extensão para a formação universitária, a articulação da extensão com as políticas públicas na área de comunicação, sua integração com o mercado de trabalho, a efetiva convergência entre universidade e a sociedade mais ampla, suas implicações discursivas em meio aos novos cenários comunicacionais, as potencialidades para a criação de novas linguagens, as relações de poder no campo, as políticas acadêmicas em relação à extensão, o direito à comunicação, entre outros aspectos referentes aos modos como a extensão universitária em comunicação se liga à formação de práticas cidadãs em suas múltiplas acepções.

Em "A extensão universitária e as demandas por justiça: cidadania e comunicação como uma questão de endereçamento”, Eliza Bachega Casadei discute a tese da indissociabilidade entre ensino, pesquisa e extensão a partir de uma reflexão sobre as demandas por direito e as demandas por justiça. De acordo com a autora, para que a extensão universitária em comunicação possa se constituir como um espaço de justiça é necessário considerar o endereçamento pressuposto nessa demanda, o que implica que a extensão deve construir um campo autônomo de atuação.

Já em "'Ser contado como falante': a interação dialógica nas práticas de extensão universitária”, Mariana Duccini Junqueira da Silva explora o conceito de interação dialógica, tal como enunciado na Política Nacional de Extensão Universitária, de 2012. A autora problematiza a questão a partir do endereçamento às comunidades atendidas pelos projetos de extensão como sujeitos de conhecimento e a necessidade da emergência de novos lugares de falaespaços estes que possibilitariam a atuação dos atores externos ao ambiente da universidade como sujeitos políticos na produção de conhecimentos. 
O livro traz um conjunto de relatos de experiências práticas na área de extensão em comunicação que enfatizam a importância desses projetos na formação dos alunos e na relação universidade-sociedade.

Paulo Roberto Figueira Leal, Rafael do Nascimento Grohmann e Rodrigo Souza Silva relatam, em "Cultura política, mídia e mobilização”, uma série de oficinas coordenadas pela Universidade Federal de Juiz de Fora. Juarez Tadeu de Paula Xavier discute as possibilidades de elaboração de políticas públicas inclusivas, via círculo de cultura, no contexto da economia criativa, no capítulo "Mapeamento dos arranjos produtivos locais intensos de cultura: tecnologias sociais para a adoção de políticas públicas inclusivas nas cidades". Já em "Observatório do Esporte: extensão e crítica da mídia esportiva na Rádio Unesp FM”, Marcos Américo, José Carlos Marques, Carlo José Napolitano e Fábio Camargo Fleury de Oliveira mostram uma proposta de interligação entre a universidade e a sociedade a partir da produção de um programa de rádio esportivo. Letícia Passos Affini e Luis Enrique Cazani Júnior descrevem a experiência do projeto Pau a Pixel no texto "A lógica do pixel e split-screen aplicada na realização da vinheta do 'Pau a Pixel: Crítica”. Por fim, Francisco Machado Filho e Mayra Fernanda Ferreira irão discorrer, em "Jornalismo colaborativo: a comunidade na prática jornalística de televisão”, sobre alguns projetos desenvolvidos no âmbito da TV Unesp, e, em "Empreendedorismo e formação profissional na extensão: a contribuição da Agência Júnior de Jornalismo da Unesp na visão de seus ex-integrantes", Francisco Rolfsen Belda irá discutir o impacto de um projeto de extensão na formação dos alunos que participaram dele.

Em comum, os capítulos apresentados pelos diferentes pesquisadores mostram problemas específicos que podem ser encontrados nos projetos de extensão na área da comunicação social, apontando para os conflitos que emergem em torno da definição de suas práticas legítimas, seu campo de atuação, seus resultados esperados, bem como os pressupostos éticos e deontológicos que organizam as práticas da extensão em comunicação social. Nesse sentido, não são 
buscadas sínteses totalizadoras sobre o papel da extensão no campo da comunicação social, mas, sim, multiplicidades de visões sobre as possibilidades do campo a partir da visão particular de cada autor de como a extensão universitária em comunicação pode se constituir como agente na construção de sujeitos cidadãos.

A partir dos problemas e propostas apresentados por esse livro, esperamos construir um espaço de enfrentamento a essas questões e de valorização da extensão universitária, em geral, e em seus desdobramentos para a comunicação social, em particular.

\section{Referências bibliográficas}

CUNHA, M. I. (org.). Qualidade da graduação: a relação entre ensino, pesquisa e extensão e o desenvolvimento profissional docente. Araraquara: Junqueira \& Marin, 2012.

DIDI-HUBERMAN, G. Diante da imagem. São Paulo: Editora 34, 2013. 


\section{1 \\ A EXTENSÃO UNIVERSITÁRIA \\ E AS DEMANDAS POR JUSTIÇA: \\ CIDADANIA E COMUNICAÇÃO COMO UMA QUESTÃO DE ENDEREÇAMENTO}

Eliza Bachega Casadei

Logo no primeiro parágrafo da Política Nacional de Extensão Universitária, coloca-se que a extensão deve ser um "instrumento de mudança social em direção à justiça, à solidariedade e à democracia" (Forproex, 2012, p.4). A palavra "justiça" aparece, ainda, em outras ocasiões no documento, como quando se afirma que "a transformação da Extensão Universitária em um instrumento efetivo de mudança da Universidade e da sociedade, em direção à justiça social e ao aprofundamento da democracia, caminha pari passu com o enfrentamento" da sensação de que se vive em uma era de grandes transformações "e a busca de novas oportunidades que se descortinam no contexto internacional e na realidade brasileira" (Forproex, 2012, p.9). É possível ler ainda que, "para que esses atores possam contribuir para a transformação social em direção à justiça, solidariedade e democracia, é preciso que eles tenham clareza dos problemas sociais sobre os quais pretendem atuar" (Forproex, 2012, p.18).

É estabelecida no documento, portanto, forte ligação entre a função da extensão universitária e as demandas por justiça social. É possível notar, ainda, outro ponto central de articulação no documento, que é aquele que vincula as demandas por justiça à busca por direitos. 
É nesse sentido que podemos ler, por exemplo, o trecho em que se estabelece que a extensão universitária deve "priorizar práticas voltadas para o atendimento das necessidades sociais (por exemplo, habitação, produção de alimentos, geração de emprego, redistribuição de renda), relacionadas com as áreas de Comunicação, Cultura, Direitos Humanos e Justiça, Educação, Meio Ambiente, Saúde, Tecnologia e Produção, Trabalho" (Forproex, 2012, p.5).

As demandas por direito inserem-se também na medida em que o documento reconhece que "a Universidade não pode substituir as responsabilidades do Estado na garantia dos direitos de cidadania ou na provisão de bens públicos, mas, sim, somar-se aos seus esforços e subsidiá-lo, de forma crítica e autônoma, no desempenho dessas atribuições" (Forproex, 2012, p.25).

A função da extensão universitária, portanto, é articulada de forma direta às demandas por direito e às por justiça. É é justamente em torno desses dois conceitos que se pode encontrar o núcleo duro da atual política nacional de extensão universitária, que diz respeito à indissociabilidade entre o ensino, a pesquisa e a extensão.

Em um dos trechos centrais do documento, por exemplo, está posto que

no que se refere à relação Extensão e Ensino, a diretriz de indissociabilidade coloca o estudante como protagonista de sua formação técnica - processo de obtenção de competências necessárias à atuação profissional - e de sua formação cidadã - processo que lhe permite reconhecer-se como agente de garantia de direitos e deveres de transformação social (Forproex, 2012, p.18).

Destaca-se, ainda, a colocação de que:

O eixo pedagógico clássico "estudante-professor" é substituído pelo eixo 'estudante-professor-comunidade'. O estudante, assim como a comunidade com a qual se desenvolve a ação de Extensão, deixa de ser mero receptáculo de um conhecimento validado pelo professor para se tornar participante do processo. Dessa forma, ele 
se torna também o tutor (aquele que apoia o crescimento possibilitado pelo conhecimento), o pedagogo (aquele que conduz, de mãos dadas, o processo de conhecimento) e o orientador (aquele que aponta a direção desse processo). Assim, no âmbito da relação entre Pesquisa e Ensino, a diretriz Indissocibialidade Ensino-Pesquisa-Extensão inaugura possibilidades importantes na trajetória acadêmica do estudante e do professor (Forproex, 2012, p.18).

O objetivo do presente capítulo é problematizar a indissociabilidade entre ensino, pesquisa e extensão sob a perspectiva de sua articulação às demandas por direito e por justiça. Se estes dois termos se colocam como fundamentadores da indissociabilidade entre as três esferas que compõem a universidade, isso resulta em uma contradição de base, posto que, a fim de que essas demandas sejam garantidas, é fundamental que haja uma dissociação entre as três instâncias.

Para que essa discussão possa ser feita, é necessário, primeiramente, delimitar e definir o que seriam as demandas por direito e as demandas por justiça. Para Derrida (2010), trata-se de termos não conciliáveis, de forma que a própria aproximação entre eles seria inoportuna e perigosa.

Em seguida, é necessário questionar em que medida a tese de indissociabilidade entre ensino, pesquisa e extensão é capaz de atender as demandas por direito ou as demandas por justiça. Se tomarmos como base a perspectiva derridariana, há no apelo à justiça um componente de particularização e endereçamento marcante que torna as lógicas próprias do ensino e da pesquisa dessemelhantes e incompatíveis com o que se tem tão ardentemente buscado em termos de cidadania e de participação política nos mais diversos projetos de extensão. E isso porque, para que o apelo à justiça se torne efetivo, é necessário não apenas o reconhecimento do outro, mas o questionamento das próprias lógicas que fundam e que estruturam as práticas - bem como uma disposição em mudar todos os pressupostos que as sustentam. O endereçar-se ao outro, nesse sentido, é um exercício constante de desfamiliarização, que dificilmente pode 
ser compatibilizado com as normalizações pressupostas no campo do ensino e da pesquisa.

Tais problemas, que serão detalhados a seguir, não apenas se mantêm, como são agravados pelas peculiaridades existentes na extensão no campo da comunicação social e seus diversos cursos universitários. A função social da comunicação a faz indubitavelmente ligada à construção da cidadania e das mediações políticas, de forma que os projetos de extensão da área, em suas mais diversas formas de estruturação e gestão, nunca estejam apartados dessa característica.

Tal como posto por Gentilli (2005, p.128), uma vez que o direito à informação pode ser entendido como uma porta de acesso a outros direitos, configura-se como um dispositivo que "fomenta o exercício da cidadania e permite ao cidadão o acesso e a crítica aos instrumentos necessários ao exercício pleno do conjunto dos direitos de cidadania". E, por isso, trata-se de um "direito que assegura outros direitos, confere condições de igualização de sujeitos e oferece visibilidade ao poder e ao mundo".

Não é por acaso que muitos projetos de extensão universitária da área de comunicação se articulem e busquem justificativas exatamente em torno dessa premissa, seja a partir do fomento da cidadania ativa (ao incentivar uma participação do público-alvo na própria produção da informação), seja a partir da produção de veículos voltados a posicionamentos ideológicos contra-hegemônicos (articulando suas publicações em torno da defesa dos direitos das classes populares e dando visibilidade a determinadas demandas ligadas a estas classes).

Os projetos de extensão na área de comunicação, portanto, sempre estão de certa maneira relacionados a tentativas de atender a demandas por direitos, de modo a ensejar demandas por justiça social.

Nesses termos, faz-se ainda mais urgente a discussão sobre até que ponto ainda devemos manter a tese sobre a indissociabilidade entre o ensino, a pesquisa e a extensão, nos cursos de comunicação social, como meio de tentar atender a demandas por direito ou por justiça. É em torno desses questionamentos que se estrutura o presente capítulo. 


\section{As demandas por direito e as demandas por justiça}

A indissociabilidade entre o ensino, a pesquisa e a extensão está fundamentada, no documento que define a Política Nacional de Extensão Universitária, a partir do reconhecimento de que a universidade tem um papel importante de atuação no que concerne às demandas sociais por direitos e por justiça, conforme colocamos anteriormente. Poderiam os projetos de extensão, de algum modo, atender a essas demandas?

Ora, para que possamos discutir o assunto, é necessário que os dois termos estejam definidos. Em Força de lei, Derrida (2010) sustenta uma diferença fundamental entre os dois tipos de demandas. Para ele, "o direito é essencialmente desconstruivel, ou porque ele é fundado, isto é, construído sobre camadas textuais interpretáveis e transformáveis (e esta é a história do direito, a possível e necessária transformação, por vezes a melhora do direito)", ao passo que "a justiça nela mesma, se algo como tal existe, fora ou para além do direito, não é desconstruível" (Derrida, 2010, p.26).

Os princípios que alicerçam as duas demandas estão postos em lugares distintos, de forma que, se para o direito, o que o fundamenta é a sua aplicabilidade imposta (enforceability), para a justiça, trata-se, fundamentalmente, de uma questão de endereçamento. E isso, em certa medida, torna as duas demandas não apenas dessemelhantes, mas irreconciliáveis, conforme explicaremos a seguir.

Para Derrida (2010), a expressão inglesa "to inforce the law" é bem mais adequada para expressar a fundamentação do direito do que as traduções equivalentes em línguas latinas como "aplicar a lei”. E isso porque "ela nos lembra, literalmente, que não há direito que não implique nele mesmo, a priori, na estrutura analítica de seu conceito, a possibilidade de ser 'enforced', aplicado pela força" (Derrida, 2010, p.8). E eis que aqui se dá a primeira e primordial diferença entre as demandas por direito e as por justiça: " to inforce the law' nos lembra que, se a justiça não é necessariamente o direito ou a lei, ela só pode tornar-se justiça, por direito ou em direito, quando detém a força, ou antes quando recorre à força desde seu 
primeiro instante, sua primeira palavra" (Derrida, 2010, p.17). E é nesse sentido que a justiça como direito não pode ser entendida como justiça nela mesma.

Nesse ponto, no entanto - se o direito é sustentado por uma força -, é necessário questionar qual é a fundamentação dessa força. Embora não seja incomum nos textos clássicos o posicionamento dessa força em um Estado mantenedor do direito (ou então, ao menos, nas forças políticas, econômicas ou sociais que o sustentam), para Derrida, essas instâncias aparecem somente a posteriori, e não como fundamento ou justificativa dessa força, que estão em um lugar anterior a essas próprias estruturas.

Uma crítica da ideologia jurídica deveria levar em consideração o fato de que "o próprio surgimento da justiça e do direito, o momento instituidor, fundador e justificante do direito, implica uma força performativa, isto é, sempre uma força interpretadora e um apelo à crença" (Derrida, 2010, p.24). E isso significa, num sentido amplo, que se trata de uma força que cria sua fundamentação em seu próprio ato de enunciação, uma força que é criada no instante mesmo de seu pronunciamento. $\mathrm{Ou}$, ainda, "na qual a enunciação não tem outro conteúdo (outro enunciado) que não seja o ato pelo qual ela se profere" (Barthes, 1988, p.68).

Se tomada sob essa perspectiva, o direito não está posto "a serviço da força, instrumento dócil, servil e, portanto, exterior do poder dominante", mas ele mantém "com aquilo que chamamos de força, poder ou violência, uma relação mais interna e mais complexa”. O direito "não estaria simplesmente a serviço de uma força ou de um poder social, por exemplo econômico, político ou ideológico, que existiria fora dele ou antes dele, e ao qual ele deveria se submeter ou se ajustar, segundo a utilidade". Ao invés disso, "a operação de fundar, inaugurar, justificar o direito, fazer a lei, consistiria num golpe de força, numa violência performativa e portanto interpretativa que, nela mesma, não é nem justa nem injusta" (Derrida, 2010, p.24).

A força do ato performativo já havia sido tratada por Derrida em outros textos, de forma que, para o autor, ela se constitui como o fundamento dos princípios de responsabilidade: 
Sem a experiência performativa deste ato de fé elementar, não haveria nem "laço social", nem endereçamento ao outro, nem qualquer performatividade em geral: nem convenção, nem instituição, nem constituição, nem estado soberano, nem lei, nem, sobretudo, aqui, essa performatividade estrutural da performação produtiva que liga desde o início o saber da comunidade científica ao fazer, a ciência, à técnica (Derrida, 1997, p.64).

É uma acepção muito próxima a de Agamben (2011), para quem, uma vez que o performativo pode ser definido como um enunciado que não descreve um estado de coisas, mas realiza imediatamente o fato em sua enunciação, ele adquire, em sua simples pronúncia, a eficácia de um ato, que só pode se realizar na medida em que efetua a suspensão do caráter denotativo normal da linguagem. "O performativo substituiu a relação denotativa entre palavra e coisa por uma relação autorreferencial que, excluindo a primeira, põe a si mesma como o fato decisivo" (Agamben, 2011, p.66).

A partir do uso da força do performativo - e sua consequente suspensão da relação denotativa - é o próprio modelo de verdade de um enunciado que é rearticulado. "O modelo de verdade não é, nesse caso, o da adequação entre as palavras e as coisas, mas sim aquele do performativo, no qual a palavra realiza inevitavelmente o seu significado". E, portanto, "assim como, no estado de exceção, a lei suspende a própria aplicação unicamente para fundar, desse modo, a sua vigência, assim também, no performativo, a linguagem suspende a sua denotação precisamente e apenas para fundar seu nexo existentivo com as coisas" (Agamben, 2011, p.66).

A implicação disso está no fato de que, para a força performativa, há uma distinção entre a própria força e seu conteúdo semântico. Nesses termos, a relação que ela estabelece com o verdadeiro está em seu próprio aspecto formal, independentemente do conteúdo que lhe serve de objeto. Enquanto articulação formal, portanto, a força performativa que alicerça o direito "não tem a ver com o enunciado como tal, mas com a garantia de sua eficácia: o que nele está em jogo não é a função semiótica e cognitiva da linguagem 
como tal, mas sim, a garantia da sua veracidade e da sua realização" (Agamben, 2011, p.12).

Para Agamben, de fato, a fundamentação do direito se articula em torno do nomen capere (tomar o nome), que ainda pode ser verificado toda vez em que é proferido um ato jurídico verbal. "A tomada do nome é nesse sentido o ato jurídico originário, e o imperativo, que Meillet define como fórmula primitiva do verbo, é o modo verbal da nomeação no seu efeito jurídico performativo. Nomear, dar nome, é a forma originária do comando" (Agamben, 2011, p.75).

$\mathrm{Na}$ argumentação derridariana, é justamente esse aspecto que faz que "a origem da autoridade, a fundação ou o fundamento, a instauração da lei não podem, por definição, apoiar-se finalmente senão sobre elas mesmas, elas mesmas são uma violência sem fundamento" (Derrida, 2010, p.26). E isso porque sua força não está em uma instituição específica, externa à sua existência, mas em sua própria eficácia performativa, que se cria no mesmo instante em que se enuncia.

Com as demandas por justiça, a fundamentação estaria em um lugar diferente. Tal como pontuamos anteriormente, não reside na aplicabilidade imposta por uma força performativa, mas em uma experiência do endereçamento. Experiência esta que, para Derrida, se constitui como uma aporia, como uma experiência do impossível: "cada vez que as coisas acontecem ou acontecem de modo adequado, cada vez que se aplica tranquilamente uma boa regra a um caso particular, a um exemplo corretamente subsumido, segundo um juízo determinante, o direito é respeitado, mas não podemos ter certeza de que a justiça o foi" (Derrida, 2010, p.30). Novamente, lembramos que existe para Derrida uma distinção entre a justiça exercida enquanto direito e a justiça exercida por si mesma.

E é por isso que o direito não é a justiça: "o direito é o elemento do cálculo, é justo que haja um direito, mas a justiça é incalculável, ela exige que se calcule o incalculável; e as experiências aporéticas são experiências tão improváveis quanto necessárias da justiça, isto é, momentos em que a decisão entre o justo e o injusto nunca é garantida por uma regra" (Derrida, 2010, p.30). 
Se a justiça não pode nunca ser garantida por uma regra cuja aplicabilidade seja universal, isso se deve ao fato de que a demanda por justiça só pode ser instalada a partir de um endereçamento preciso e localizável. É esse endereçamento que não apenas garante sua condição de inteligibilidade como também seu cumprimento e efetivação. E isso porque o justo só pode ser considerado correto para alguém se forem recusadas todas as demandas universais. $\mathrm{O}$ justo é sempre algo particular.

Nos dizeres de Derrida (2010, p.31), "o endereço, como a direção, como a retidão, diz algo acerca do direito, e aquilo a que não devemos faltar quando queremos a justiça, quando queremos ser justos, é a retidão do endereço. Não devemos carecer de endereço, mas, sobretudo, não devemos errar de endereço, não devemos nos enganar de endereço". E isso porque "um endereço é sempre singular, idiomático; enquanto a justiça, como direito, parece sempre supor a generalidade de uma regra, de uma norma ou de um imperativo universal".

Nesses termos, não há conciliação possível entre as demandas por direito e as demandas por justiça, posto que o direito supõe a aplicabilidade de uma regra universal e a justiça, por sua vez, concerne sempre a singularidades insubstituíveis cuja individualidade as formas gerais das regras e do cálculo não podem jamais subsumir. Utilizando-se de uma ideia bastante benjaminiana de história, para Derrida,

há um porvir para a justiça, e só há justiça na medida em que seja possível o acontecimento que, como acontecimento, excede ao cálculo, às regras, aos programas, às antecipações etc. A justiça, como experiência de alteridade absoluta, é inapresentável, mas é a chance do acontecimento e a condição da história. Uma história sem dúvida irreconhecível, claro, para aqueles que pensam saber do que falam quando usam essas palavras, quer se trate de história social, ideológica, política, jurídica etc. [...] Abandonada a si mesma, a ideia incalculável e doadora da justiça está sempre mais perto do mal, ou do pior, pois ela pode sempre ser reapropriada pelo mais perverso dos cálculos (Derrida, 2010, p.55). 
Não é por acaso que o direito, para efetivar-se, seja personalizado sempre na figura de um juiz - que pode ser entendido como a metaforização de um terceiro que, a cada caso individual, julga se uma lei é justa de ser aplicada ou não. Ora, é exatamente nesses termos que Ricoeur (2007) define essa figura: "designado por sua intenção de verdade e de justiça", a sociedade convida-o "a ocupar a posição do terceiro em relação aos lugares ocupados no espaço público pelos protagonistas da ação social”. Esse papel é importante na medida em que "um desejo de imparcialidade está ligado a essa posição de terceiro", mesmo que essa se apresente "sob o signo da impossibilidade de um terceiro absoluto” (Ricoeur, 2007, p.330).

O juiz é a figura que tenta conciliar as demandas por direito às demandas por justiça na medida em que ele é o ator que garante que a regra não será meramente aplicada a partir de um princípio universal, mas que cada caso será visto em sua singularidade.

"O juiz deve não apenas seguir uma regra de direito ou uma lei geral, mas deve assumi-la, aprová-la, confirmar seu valor, por um ato de interpretação reinstaurador, como se a lei não existisse anteriormente, como se o juiz não a inventasse ele mesmo em cada caso". Eis a importância do ritual do julgamento, na medida em que não se baseia meramente em uma lei preexistente, mas na "interpretação reinstauradora, reinventiva e livremente decisória do juiz responsável" que "requer que sua 'justiça' não consista apenas na conformidade, na atividade conservadora e reprodutora do julgamento" (Derrida, 2010, p.44).

Isso posto, no entanto, é o próprio dever de reinstaurar a lei em cada caso que, para Derrida, coloca as demandas por justiça e as demandas por direito em campos não apenas opostos, mas dessemelhantes da ação social. Isso porque o recurso ao terceiro (ao juiz ou a outra instância) se opõe à própria perspectiva do endereçamento (que é o fundamento primordial das demandas por justiça). Em suas próprias palavras, "endereçar-se a outrem na língua do outro é, ao mesmo tempo, a condição de toda justiça possível, ao que parece, mas isso parece não apenas rigorosamente impossível, mas até mesmo excluído da justiça como direito", na medida em que "pa- 
rece implicar um elemento de universalidade, o recurso ao terceiro que suspende a unilateralidade ou a singularidade dos idiomas" (Derrida, 2010, p.32).

O terceiro - enquanto instância mediadora - é também aquele que torna todo endereçamento impossível, portanto. ${ }^{1} \mathrm{O}$ endereçamento, na concepção derridariana depende de um apelo (ao mesmo tempo necessário e impossível) a uma relação heteronômica a outrem - "ao rosto de outrem, que me comanda, cuja finalidade não posso tematizar e da qual sou refém” (Derrida, 2010, p.41) - que está alicerçada nas ideias de Levinas. Tais pressupostos colocam esse outro não como um igual, mas como a figura de uma dessimetria absoluta e inatingível.

A filosofia de Levinas se estrutura, justamente, a partir de uma crítica radical à ideia de outro tradicionalmente posta pela filosofia ocidental que, ao falar de alteridade, apenas reforçaria a questão do Eu, de forma que o Ser fica reduzido em Ser-em-Si-Mesmo: "o primado do Mesmo foi a lição de Sócrates: nada receber do Outrem a não ser o que já está em mim, como se, desde a eternidade, eu já possuísse o que me venha de fora" (Levinas, 2000, p.31). O outro, para Levinas deveria ser entendido não dessa forma, mas como uma alteridade absoluta e radical - um outro que eu não posso entender e que me ameaça constantemente, embora se apresente como a única esfera possível para o estabelecimento de uma ética.

O sujeito, em Levinas, é constituído a partir de uma relação absolutamente assimétrica com esse outro, de forma que:

O absolutamente Outro é Outrem; não faz número comigo. A coletividade em que eu digo "tu" ou "nós" não é um plural de um "eu”. Eu, tu, não são indivíduos de um conceito comum. Nem a

1 Reiterando a ideia de dessemelhança, Derrida aponta que as aporias presentes entre as duas esferas explicitarão "uma distinção entre a justiça e o direito, uma distinção difícil e instável entre, de um lado, a justiça (infinita, incalculável, rebelde às regras, estranha à simetria, heterogênea e heterotrópica) e, de outro lado, o exercício da justiça como direito, legitimidade ou legalidade, dispositivo estabilizável, estatutário e calculável, sistema de prescrições regulamentadas e codificadas" (Derrida, 2010, p. 41). 
posse, nem a unidade do número, nem a unidade do conceito me ligam a outrem. Ausência de pátria comum que faz do Outro o Estrangeiro; o Estrangeiro que perturba o "em sua casa". Mas o estrangeiro quer dizer também o livre. Sobre ele não posso poder, porquanto escapa ao meu domínio num aspecto essencial (Levinas, 2000, p.26).

Apesar da outridade absoluta, há, em Levinas, a possibilidade de estabelecimento de uma relação a partir da ética, de uma obrigação que se impõe em relação a essa alteridade: "é precisamente nesse chamado que a responsabilidade do eu pelo rosto que o convoca, que o suplica e que o reclama, que o Outrem é próximo do Eu" (Levinas, 2000, p.276).

É esse o sentido adotado por Derrida quando trata da questão do endereçamento. Endereçar-se ao outro (o que é o mesmo que fazer justiça ao outro) é correr riscos porque se está sempre diante da outridade absoluta, que, embora não nos desobrigue de uma relação ética, questiona nossos próprios sistemas de validações e de normas (os próprios fundamentos do direito, por fim).

Postas as aporias na mesa, portanto, o que nos resta depois de reconhecida a impossibilidade de conciliação entre as demandas por direito e as demandas por justiça? E, mais do que isso, qual o papel da universidade nesse quadro? Pode a extensão universitária se estabelecer como uma instância, se não mediadora, pelo menos socialmente responsável e motivada? Pode ela atender seja a demandas por direitos, seja a demandas por justiça? E, sem mais, a indissociabilidade entre a pesquisa, o ensino e a extensão nos ajuda a reconhecer a outridade do outro ou, por fim, a nega?

\section{A dissociabilidade entre ensino, pesquisa, extensão e o reconhecimento do outro}

A tese da indissociabilidade entre o ensino, a pesquisa e a extensão está sustentada, no documento que define a Política Nacional 
de Extensão Universitária, elaborado em 2012, na função da extensão em atender as demandas sociais por direitos e por justiça. Conforme discutimos no tópico anterior, a própria aproximação entre os termos pode ser problemática, de forma que é conveniente separar essas duas esferas.

Comecemos, então, pelas demandas por direitos. Especificamente no que concerne aos projetos de extensão no campo da comunicação, existe sempre um apelo ao próprio direito à informação.

Embora a maior parte dos ordenamentos jurídicos reconheça o direito à informação e o direito à liberdade de expressão como garantias constitucionais ligadas à comunicação, são poucos os países que construíram mecanismos jurídicos que permitam à população a prerrogativa e a capacidade de se expressar publicamente. Como pontuam Brittos e Collar (2008, p.72), tais discussões remontam à década de 1960 e ainda não foram incorporadas às leis internacionais, muito embora alguns países já reconheçam o direito de acesso da sociedade aos meios de comunicação.

Em um sentido amplo, o direito à comunicação pode ser entendido a partir de quatro pressupostos centrais, que envolveriam "a liberdade de expressão na esfera pública, o uso do conhecimento e do domínio público, o pleno exercício das liberdades civis (privacidade, associação) e o acesso equitativo às tecnologias de informação e comunicação" (Brittos; Collar, 2008, p.79).

No Brasil, "existe o entendimento minoritário de que o direito à comunicação já está previsto na Constituição Federal de 1988, em seu artigo 220, que dispõe sobre a proibição de restrições a manifestações de pensamento e à liberdade de expressão e informação" (Brittos; Collar, 2008, p.72), contudo não há um ordenamento específico que garanta o acesso mais equânime aos meios. $\mathrm{Ou}$, em outros termos, que afirme o direito à comunicação como o direito a comunicar.

Diante da falta de um ordenamento jurídico específico, os próprios projetos de extensão não podem atender a essa demanda, na medida em que não podem abarcar, em sua esfera, a aplicabilidade 
imposta (enforceability) própria do campo do direito, tal como definido anteriormente.

O mesmo pode ser dito em relação a demandas por outros direitos que eventualmente os projetos de extensão possam contemplar. Uma vez que é justamente a enforceability que define essa esfera, esses pressupostos estariam fora da alçada dos projetos de extensão, que podem, no máximo, dar visibilidade a essas demandas. Tal visibilidade, contudo, não garante a efetivação do direito e, portanto, não se aplica à discussão nessa esfera, sendo necessário reavaliar os próprios termos do debate.

Resta-nos avalizar, portanto, o que pode ser dito em relação às demandas por justiça.

Derrida sugere alguns campos relacionais possíveis. Para ele, a relação com o outro, embora nunca deixe de ser aporética quanto às demandas por direito e por justiça, pode se tornar ao menos pensável diante da disposição de abraçar a heterogeneidade, ou seja, se reconhecermos o seguinte fato: "não apenas é preciso calcular, negociar a relação entre o calculável e o incalculável, e negociar sem regra que não esteja por reinventar [...] onde nos encontramos", mas isso necessita ser feito "tão longe quanto possível, para além do lugar em que nos encontramos e para além das zonas já identificáveis da moral, da política ou do direito, para além da distinção entre o nacional e o internacional, o público e o privado etc.". Mais do que isso, é necessário reconhecer que "a ordem desse é preciso não pertence propriamente nem à justiça nem ao direito. Ela só pertence a um dos dois espaços transbordantes sobre o outro" (Derrida, 2010, p.56). A fim de assegurar a justiça para além das regras é necessário, portanto, desacostumar-se das próprias regras para reinscrevê-las.

Renegociar sem regra a relação entre o calculável e o incalculável, sob o ponto de vista dos projetos de extensão e seus pressupostos pelo atendimento das demandas por justiça, significa fazer esse cálculo longe dos pressupostos acadêmicos - ou seja, longe dos limites que prescrevem o certo e o errado sob uma perspectiva das normas e dos ensinamentos consagrados seja pela prática, seja pelos métodos científicos, educacionais ou profissionais. Isso porque, 
sob uma perspectiva derridariana, a justiça é aquilo que sobra para além das regras; é a própria reinscrição da regra fora do lugar de onde elas foram originalmente demarcadas.

Nesse sentido, há outro ponto que deve ser levado em consideração e que é identificado pelo próprio Derrida (2010, p.56): "para que isso não seja um truísmo ou uma trivialidade, é necessário reconhecer a seguinte consequência: cada avanço na politização obriga a reconsiderar, portanto, a reinterpretar, os próprios fundamentos do direito, tais como eles haviam sido previamente calculados ou delimitados". Mais do que isso, é necessário "reelaborar o conceito de emancipação, de franqueamento ou de libertação, levando em conta as estranhas estruturas que descrevemos nesse momento".

Se transportarmos essa questão para a demanda de justiça pressuposta nos projetos de extensão na área da comunicação, isso significa reconsiderar todos os pressupostos das práticas - às vezes naquilo que elas possuem de mais fundamental e consolidado. Para serem justos (ou, em termos mais precisos, para atender às demandas por justiça), os projetos de extensão da área de comunicação, sob essa perspectiva, precisam colocar as próprias práticas comunicacionais em risco e, com isso, empenhar-se na ameaça de minar suas próprias bases a partir da abertura ao outro - movimento sempre imprevisível e perigoso.

Se pensarmos em termos práticos, em projetos de extensão de cunho jornalístico, por exemplo, isso significa reposicionar as próprias regras do jogo jornalístico, muitas vezes negando sua linguagem, a sua estrutura, a sua forma particular de conceber o mundo e os seus conteúdos mais fundamentais. E isso valeria para todas as demais práticas do campo da comunicação.

Para Bourdieu (1983), o espaço social é sempre construído a partir de princípios de diferenciação a partir dos quais cada grupo busca a delimitação de um território próprio com o objetivo de conseguir determinadas vantagens ligadas ao capital simbólico. Cada campo profissional é estruturado segundo um conjunto específico de regras profissionais de ação. Toda prática está sujeita à produção constante de "operações de conhecimento, submetidas a técnicas de 
saber, critérios de validação ou regimes de prova" (Chartier, 2010, p.20) que são específicos. Há mesmo a instalação de uma espécie de jogo de espelhos, em que se refletem os princípios e normas validados pelo grupo mais amplo e que determinam os procedimentos validados de trabalho.

A educação é um dos principais meios a partir dos quais as normas e regras do campo são reproduzidas entre seus membros integrantes, de forma que ela tem um papel importante na cooptação e inserção dos novos membros nos valores compartilhados pela comunidade profissional mais ampla. $\mathrm{O}$ mesmo pode ser dito acerca das práticas de pesquisa, em que todos os resultados são validados a partir do reconhecimento dado pela comunidade científica mais ampla formada pelos pares acadêmicos, de acordo com um campo metodológico e epistemológico.

A extensão, se desejosa de atender as demandas por justiça, deve justamente opor-se a esse sistema de normas e convenções pressupostas na (e importantes para) estruturação das práticas de ensino e de pesquisa. A extensão universitária pode articular-se justamente como esse espaço do contra, questionador das regras, dos cálculos, da linguagem, dos padrões de qualidade, das normas éticas, dos espaços consolidados. Um lugar que assume o risco da outridade absoluta.

Ocupar esse espaço nunca é algo trivial ou tranquilo. Aceitar o endereçamento como fundamento das demandas por justiça significa abraçar a heterogeneidade não apenas naquilo que o outro possui de belo, bom e justo. Significa, também, abraçar tudo o que de idiossincrático, preconceituoso, supersticioso e errado o outro carrega. O que implica dizer que a relação é sempre de conflito e de luta por posicionamentos de poder e, pode, no máximo, articular-se mais enquanto disposição mútua do que enquanto acordos normativos. Trata-se mesmo, como apontado por Derrida, de um espaço aporético e problemático, mas cuja articulação pode constituir-se como a própria função da extensão universitária, posto que as outras instâncias (o ensino e a pesquisa) jamais poderiam, por definição, o abarcar. 


\section{Considerações finais}

Tal como formulado pelo próprio Derrida (2010, p.38) “toda desconstrução dessa rede de conceitos, em seu estado atual ou dominante, pode assemelhar-se a uma irresponsabilização, quando, pelo contrário, é a um acréscimo de responsabilidade que a desconstrução faz apelo".

Distender a rede que urde o ensino, a pesquisa e a extensão nos projetos em comunicação, sob essa perspectiva, significa exatamente isso: desvincular-se das normas que estruturam as duas primeiras esferas para que a extensão não seja uma mera reprodutora de conteúdos e consiga construir seu espaço específico para o atendimento das demandas por justiça. Significa, em um aspecto mais amplo, o empoderamento da própria extensão universitária a partir do abandono das ideias de tutoria e orientação do outro. Significa, ainda, a promoção de um embate constante entre a extensão, de um lado, e o ensino e a pesquisa, de outro - embate esse cujas consequências são imponderáveis e, por isso mesmo, extremamente necessárias para o campo.

\section{Referências bibliográficas}

AGAMBEN, G. O sacramento da linguagem: arqueologia do juramento. Belo Horizonte: Editora UFMG, 2011.

BARTHES, R. O rumor da lingua. São Paulo: Brasiliense, 1988.

BOURDIEU, P. A economia das trocas simbólicas. São Paulo: Perspectiva, 1983.

BRITTOS, V. C.; COLLAR, M. S. Direito à comunicação e democratização no Brasil. In: SARAVIA, P.H.; MARTINS, P.E.M.; PIERANTI, O.P. (Orgs.). Democracia e regulação dos meios de massa. Rio de Janeiro: Editora FGV, 2008.

CHARTIER, R. A história ou a leitura do tempo. Belo Horizonte: Autêntica, 2010.

DERRIDA, J. Fé e saber: as duas fontes da "religião" nos limites da simples razão. In: DERRIDA, J.; VATTIMO, G. (dir.). A religião: seminário de Capri. Lisboa: Relógio D’Água, 1997. 
DERRIDA, J. Força de lei. São Paulo: Martins Fontes, 2010.

FORPROEX. Política Nacional de Extensão Universitária. Manaus: [s.n.], 2012. Disponível em: http://www.renex.org.br/documentos/2012-0713-Politica-Nacional-de-Extensao.pdf. Acesso em: 23 jan. 2015.

GENTILLI, V. Democracia de massas: jornalismo e cidadania. Porto Alegre: EDIPUCRS, 2005.

LEVINAS, E. Totalidade e infinito. Lisboa: Edições 70, 2000.

RICOEUR, P. A memória, a história, o esquecimento. Campinas: Editora da Unicamp, 2007. 


\section{2 \\ "Ser contado como falante": \\ A INTERAÇÃO DIALÓGICA NAS PRÁTICAS DE EXTENSÃO UNIVERSITÁRIA}

Mariana Duccini Junqueira da Silva

Conceito central no enunciado da Política Nacional de Extensão Universitária de 2012 (Forproex, 2012), a interação dialógica, assumida como uma das diretrizes para as ações extensionistas, é vista como o "cerne da dimensão ética" desses processos. Afirma-se ainda, no documento, a necessidade de que as populações cujos problemas se tornam objeto de pesquisa acadêmica sejam necessariamente consideradas como sujeitos do conhecimento produzido nas relações entre o espaço universitário e a comunidade. Nesse âmbito, não haveria como se conceber a interação dialógica alheiamente a sua dimensão política, aquela que interrompe uma ordem de dominação naturalizada para instituir "uma parcela dos sem parcela” (Rancière, 1995). O que caracteriza, entretanto, a conversão desses atores sociais em sujeitos de qualquer exercício de saber e de comunicação seria, ainda conforme Rancière, sua capacidade de logos, ou seja, a participação em uma comunidade sob os termos da posse e da legitimação de uma linguagem (e não apenas de sua compreensão).

"Ser contado como falante", assim, coloca em jogo a própria condição de enunciação desses sujeitos, o que facultaria um reordenamento das regras, geralmente tácitas, que modulam as formas de participação dos atores sociais em um universo comum de 
experiências e saberes. Este texto intenta problematizar o conceito de interação dialógica, propondo uma reflexão acerca da extensão universitária quanto a relações entre linguagens: a emergência de novos lugares de fala (novos regimes de expressão) que possibilitariam a atuação dos atores externos ao ambiente da universidade como sujeitos na produção de conhecimentos.

A dimensão propriamente política desse processo orienta-se, de saída, pelo questionamento quanto a uma pretensa condição igualitária "garantida" a todos os envolvidos nas práticas extensionistas, cuja gênese e desenvolvimento no Brasil, já no início da segunda década do século passado, estiveram fortemente respaldados ora pelo viés do assistencialismo social, ora pelo intuito da prestação de serviços. Nesse contexto, é razoável considerar a efetividade restrita de uma troca de conhecimentos entre a comunidade acadêmica e o público a que eram dirigidos os programas de extensão universitária. Em termos práticos, essas ações "foram instrumentos de divulgação do ensino nas universidades, complementando a formação de seus alunos e atualizando seus egressos" (Nogueira, 2001, p.59).

Frequentemente entendidos como "receptores" de um saber produzido nos limites da academia - em termos de uma estratégia de autorização e validação desse saber, que encontra no lugar do "outro" um espaço propício para a própria aplicação -, os atores externos às instituições universitárias dificilmente eram considerados como agentes de transformação, propensos a se emancipar por meio dos fazeres cotidianos que conformam seu universo simbólico.

Certo apelo salvacionista prestou-se então à legitimação tácita que considerava, na ordem das ações de extensão, uma dissimetria de inteligências e de capacidades entre os representantes da academia (docentes, alunos, categorias técnico-administrativas) e as comunidades agenciadas. Com o propósito de minorar a suposta ignorância daqueles cuja prática empírica obliterava a reflexão, ou ainda seguindo diretrizes que visavam ao aumento da produção (sobretudo em áreas agrícolas) e às questões de segurança nacional, especialmente no âmbito da ditadura civil-militar instalada em 1964, os projetos de extensão universitária encarnaram a concepção me- 
canicista que valora o conhecimento na égide de sua transmissão. Tal disparidade de competências entre aqueles que "estendem" o saber e aqueles que o "recebem" é, na prática, naturalizada como pressuposto, em que pese a argumentação crescente quanto à troca de conhecimentos, que vai se literalizando nas políticas norteadoras da extensão universitária, como desenvolveremos a seguir.

Se qualquer troca pressupõe uma condição elementar de igualdade, aquela que situa os sujeitos em um universo comum de significados e de possibilidades de ocupação de lugares de fala, a interação dialógica não haverá de se viabilizar em um contexto em que a desigualdade de posições enunciativas - de articulação de discursos que se suponham legítimos - seja tão incidente quanto naturalizada.

A condição igualitária, entretanto, não é meramente um dado das relações intersubjetivas, mas uma dinâmica que se constrói politicamente, isto é, com o reconhecimento e a nomeação de um dano que institui a "parcela dos sem-parcela" (Rancière, 1995). Apenas com a reivindicação e a inscrição dos "sem-parcela" nessa cena, dissensual por natureza, pode-se conceber uma ação de ordem política, que desnaturaliza e expõe a própria desigualdade, desentranhando-a de um "estado das coisas".

Ocupar uma cena como sujeito de enunciação, ser contado como falante, implica a faculdade de se tomar publicamente a palavra outrora interditada. Para além da aparente tautologia, esse processo se torna possível quando discursos até então silenciados na condição de ruídos passam a ser valorados como expressões de um logos, que nunca será mera articulação de palavras, mas "palavra que conta" (Rancière, 1995, p.36), potente para reconfigurar as relações de poder em jogo em determinado campo de relações intersubjetivas.

É sob essa perspectiva que a interação dialógica, dimensão ética por excelência das políticas de extensão universitária, impele-nos à reflexão quanto aos exercícios de poder - eles próprios dinâmicas de linguagem - nas práticas cotidianas das universidades públicas. Se tal interação pressupõe engajamento e transformação mútua de todos os indivíduos que compartilham uma produção de conheci- 
mentos, os termos em que se configuram as políticas de extensão na academia devem antever e viabilizar a troca, a interlocução e, consequentemente, a equivalência dos papéis dos sujeitos dessas ações.

Não se trata, evidentemente, de indiferenciar os interesses e as experiências de indivíduos e de comunidades em nome de uma ingênua homogeneidade de atuações e resultados nas práticas extensionistas. O que está em jogo é a necessidade de que atores comumente considerados como receptores de teorias e metodologias engendradas nos espaços da academia sejam, verdadeiramente, interlocutores: aqueles que se podem colocar em cena para reivindicar a própria condição dissensual, fissurando os discursos estabelecidos e fazendo-se contar como sujeitos da reflexão sobre um mundo em que se partilham não apenas modos de vida, mas também possibilidades de reconfiguração desses modos.

\section{Breve percurso das ações e políticas extensionistas no Brasil}

De forma embrionária, as ações extensionistas nas universidades brasileiras remontam aos anos 1910 e 1920, com a oferta de cursos e palestras abertos à comunidade, na antiga Universidade de São Paulo; ou ainda com atividades de assistência técnica em comunidades rurais, desenvolvidas pelas antigas Escola Agrícola de Lavras e Escola Superior de Agricultura e Veterinária de Viçosa, em Minas Gerais. Em todos esses casos, foi determinante a influência de conceitos relativos à extensão então vigentes na Europa, em que era preconizada a ideia de educação continuada (com a apresentação de cursos e conferências pontuais), e nos Estados Unidos, em que a tônica dessas atividades era orientada pelo intuito da prestação de serviços a comunidades rurais e urbanas (Nogueira, 2001).

Nas décadas seguintes, os programas de extensão seguiram em geral restritos a essas concepções - e, na prática, eram destinados sobretudo a aprimorar a formação de públicos que já estavam liga- 
dos às universidades. A falta de institucionalização e de políticas consistentes a orientar a extensão universitária imprimia a essas atividades uma importância apenas acessória no contexto das instituições públicas de ensino, em que não raro o papel da própria universidade era circunscrito ao da execução de técnicas junto de comunidades que se mantinham apartadas do protagonismo na produção de conhecimentos e, especialmente, da reflexão quanto ao impacto dessas experiências em suas formas de relação com o mundo sensível. A substituição dos fazeres empíricos pelos da ciência aplicada, nesse contexto, refletia um ideal de progressismo que desautorizava não somente práticas consolidadas no cotidiano das comunidades, mas também formas peculiares de construção da realidade, concepção que sustentava:

uma inegável descrença no homem simples. Uma subestimação de seu poder de refletir, de sua capacidade de assumir o papel verdadeiro de quem procura conhecer: o de sujeito dessa procura. Daí a preferência por transformá-lo em objeto do "conhecimento" que se lhe impõe (Freire, 1983, p.30, grifo do autor).

Nos anos que antecederam o golpe militar de 1964, entretanto, o posicionamento da União Nacional dos Estudantes (UNE) em favor de uma reforma universitária, no anteparo das lutas por transformações de base que mobilizaram diversos setores produtivos do país, como o operariado e o campesinato, impactou as formas de gestão da ação extensionista. Comprometida com iniciativas de alfabetização de adultos (amplamente influenciadas pelo trabalho de Paulo Freire) e campanhas pela erradicação de doenças em zonas rurais (com o Ministério da Saúde), a UNE também se engajou em ações educativas nas áreas urbanas, especialmente com a estruturação do Centro Popular de Cultura (CPC), em 1961, que, "mediante a literatura, o teatro, a música e o cinema, sobretudo, buscou levar às favelas e às aglomerações populares o esclarecimento, a denúncia, o protesto, a propaganda de uma nova sociedade, que era possível ser construída” (De Paula, 2013, p.15). 
O contexto dessa atuação permitia vislumbrar um entendimento mais complexo quanto ao exercício da extensão universitária, posto que, às iniciativas pontuais e episódicas, orientadas pelo propósito da transmissão de informações e não raro dissociadas da realidade das populações "atendidas", a proposta do movimento estudantil reivindicava uma reordenação do próprio papel das instituições públicas de ensino. O que estava no horizonte era a defesa de uma universidade alinhada às causas populares, competente para arregimentar esforços na emancipação intelectual dos estratos mais desfavorecidos. É nesse âmbito, sublinhamos, que as conquistas do movimento estudantil não podem ser desvinculadas de um espectro mais amplo das reformas sociais reivindicadas naquele período, desmobilizadas com a ascensão da ditadura civil-militar.

$\mathrm{O}$ viés assistencialista, conjugado a interesses de soberania nacional e de desenvolvimentismo, permeou o andamento dos programas de extensão durante o regime, que, embora visse nas universidades um meio estratégico de disseminação ideológica, limitava severamente o potencial reflexivo e emancipador que, ao menos em tese, representaria uma das principais vocações do meio acadêmico. Mais além, a atuação de quadros universitários (especialmente estudantes) junto a populações alijadas de condições básicas de existência prestava-se a "minimizar, com o assistencialismo, os efeitos negativos das políticas macroeconômicas sobre o emprego, os salários, as condições de vida do povo, os investimentos em infraestrutura etc." (Nogueira, 2005, p.7).

Amplamente divulgadas pelo regime militar, as principais iniciativas no que diz respeito às políticas extensionistas nesse período foram o Projeto Rondon, instituído em 1967 com o intuito de propiciar aos estudantes brasileiros o contato sem mediações com a realidade das regiões mais assoladas pela miséria, e o Centro Rural de Treinamento e Ação Comunitária (CRUTAC), criado em 1966 na Universidade Federal do Rio Grande do Norte. A concepção e os resultados dessas ações suscitam análises complexas, mesmo ambivalentes. Se, por um lado, a forte dependência do ideário programático da ditadura civil-militar cerceava ao máximo o potencial 
reflexivo da troca de experiências entre a academia e as comunidades (muitas das ações eram esporádicas ou descontinuadas), por outro, a própria natureza dessa convivência logrou transformações importantes entre os atores sociais envolvidos:

A despeito de sua subordinação à política de segurança nacional e de seu caráter cooptativo, esses dois projetos tiveram o mérito de propiciar ao universitário brasileiro experiências importantes junto às comunidades rurais, descortinando-lhe novos horizontes e possibilitando-lhe espaços para contribuir para a melhoria das condições de vida da população do meio rural (Forproex, 2012, p.6-7).

Com o processo de redemocratização, ${ }^{1}$ as discussões sobre a extensão universitária tornam-se mais sistemáticas, sublinhando a necessidade de institucionalização dessa prática no cotidiano da academia e buscando progressivamente a indissociabilidade entre essa esfera e as do ensino e da pesquisa. A responsabilidade social das universidades quanto à formação cidadã (na esteira da Constituinte de 1988), não apenas de seus quadros imediatos, mas também das comunidades externas, dá a ver a necessidade de

1 Como nenhum processo histórico se dá inexoravelmente segundo uma linearidade cronológica, mas compreende temporalidades distintas, o desenvolvimento das práticas e políticas extensionistas no Brasil é marcado por iniciativas mais ou menos bem-sucedidas, muitas vezes concomitantes. A esse respeito, é pertinente aludir à elaboração pelo Ministério da Educação (MEC) da primeira Política de Extensão Universitária no país, em 1975, ainda durante a vigência do regime militar: "embora concebido sob forte controle da censura, [essa política] apresenta um significativo avanço conceitual quanto à Extensão", sobretudo por: ampliar e especificar os públicos a serem envolvidos nas ações extensionistas; acenar para a necessidade de articulação entre o ensino, a pesquisa e a extensão; defender o envolvimento mais efetivo dos docentes nessas atividades; e situar a relação entre a universidade e as comunidades externas não mais sob a égide da transmissão de informações, mas em vista da troca entre saber acadêmico e saber popular, por uma construção de conhecimentos confrontados com a realidade (Nogueira, 2001, p.64 e seguintes). 
ações multidisciplinares e reitera a dimensão da troca entre os atores sociais que tomam parte nas atividades extensionistas.

É nesse âmbito que a recorrência do conceito de interação dialógica se faz sensível, materializando a primeira das diretrizes da atual Política Nacional de Extensão Universitária (2012), documento que se engendra a partir de reflexões e debates sobre o Plano Nacional de Extensão Universitária de 1999 (2001).

Dentre os fundamentos da interação dialógica, a Política de 2012 especifica: a aliança das universidades com os movimentos, setores e organizações sociais; a produção de conhecimentos em interação com a sociedade (pressupondo que as práticas de extensão sejam concebidas como um exercício de mão-dupla); a incorporação de metodologias que viabilizem a democratização dos saberes, assim como da autoria quanto aos conhecimentos construídos; e a participação efetiva dos membros de diferentes segmentos sociais nos espaços da universidade pública.

Inegavelmente mobilizado pela importância fundamental da interação dialógica nos processos extensionistas, o texto da Política de 2012 sublinha também o compromisso dessa ação com "o enfrentamento da exclusão e vulnerabilidade sociais e o combate a todas as formas de desigualdade e discriminação" (Forproex, 2012, p.26), no contexto da articulação dos projetos de extensão com os movimentos sociais.

O que pretendemos assinalar como central em nossa reflexão é que a ideia de interação dialógica apresenta problematizações intrínsecas, implicadas em sua própria natureza conceitual.

Por um lado, a condição dialógica é o princípio elementar de toda vida subjetiva, já que "o centro organizador de toda enunciação, de toda expressão, não é o interior, mas o exterior: está situado no meio social que envolve o indivíduo [...]. A enunciação enquanto tal é um puro produto da interação social" (Bakhtin, 2004, p.121). Por outro lado, tal condição de fundamento em toda atividade humana (o dialogismo) não pode ser confundida com o diálogo propriamente dito, ou seja, a presentificação de uma troca verbal orientada pela equivalência de posições dos interlocutores. Isso porque nem todos 
os indivíduos "estão habilitados", indiscriminadamente, a tomar a palavra - ou, reiteramos, a ser contados como falantes, como interlocutores legítimos. O "malogro da igualdade" então se verifica porque toda comunidade se institui segundo um princípio de polícia: a regulação de uma divisão do espaço sensível que procede a uma distribuição simbólica dos corpos, determinando aqueles que são portadores de logos e aqueles que não são (Rancière, 1995).

A ação política torna-se, então, o único modo de subversão (ainda que situado, contingente) do princípio de polícia: quando aqueles que não são tidos como pertencentes a uma comunidade tornam-se capazes de expor tal condição, fazendo-se considerar pela instalação do dissenso, podem reivindicar a igualdade interlocutiva, ainda que em uma cena estruturada pela desigualdade. A "parte dos sem parte", assim, inscreve-se em um espaço de enunciação, rearticulando as formas identitárias que até então lhe foram impostas e redefinindo suas formas de participação em um universo comum da experiência.

\section{O dissenso como possibilidade da interação dialógica: uma nova ordem de ficções}

Se nos ativermos ao breve percurso, aqui apresentado, das políticas extensionistas no Brasil, é razoável pensar nos atores externos ao ambiente universitário como a referida "parte dos sem parte". Não porque estivessem literalmente apartados dessas ações, mas, com efeito, pelas maneiras como foram predominantemente cooptados, levados em conta no processo.

A própria concepção da extensão como um meio de se estender ou transmitir conhecimentos, com a predominância do viés assistencialista que permeou a história dessas atividades, faz supor uma "vontade de reificação" relativa a esses indivíduos e grupos. Depositários - mas não autores - de um conhecimento cuja produção e valoração foram quase sempre da alçada das elites acadêmicas, sua moeda de pouco lastro nessa relação mecanicista era a suposta ig- 
norância que urgia ser minorada, o empirismo pouco reflexivo que demandava o trabalho da ciência aplicada para que fosse conduzido a "bom termo".

É também nesse aspecto que a ignorância não se justifica, ideologicamente, como uma disparidade entre saberes, mas efetivamente como uma disparidade entre posições: a medida de uma distância que determina quem pode tomar o lugar de enunciação, segundo regras e protocolos cuja ritualização social acaba por naturalizar. É escusado explicar por que essa concepção, longe de lograr a propagada emancipação dos atores sociais - sua conversão em sujeitos legítimos do conhecimento -, apenas reproduz, como se esse fosse um dado do mundo, as desigualdades sociais e os parâmetros que distinguem o logos da alogia, o discurso autorizado e os ruídos, as posições de quem pode e de quem não pode tomar parte em uma comunidade.

A distância que o ignorante precisa transpor não é o abismo entre sua ignorância e o saber do mestre. É simplesmente o caminho que vai daquilo que ele já sabe àquilo que ele ainda ignora, mas pode aprender como aprendeu o resto, que pode aprender não para ocupar a posição do intelectual, mas para praticar melhor a arte de traduzir, de pôr sua experiência em palavras e suas palavras à prova, de traduzir suas aventuras intelectuais para uso dos outros e de contratraduzir as traduções que eles lhes apresentam de suas próprias aventuras. O mestre ignorante capaz de ajudá-lo a percorrer esse caminho é assim chamado não porque nada saiba, mas porque abdicou do "saber da ignorância" e assim dissociou sua qualidade de mestre de seu saber. Ele não ensina seu saber aos alunos, mas ordena-lhes que se aventurem na floresta das coisas e dos signos, que digam o que viram e o que pensam do que viram, que o comprovem e o façam comprovar. O que ele ignora é a desigualdade das inteligências (Rancière, 2012, p.15-16).

Quanto à ação de ignorar a desigualdade das inteligências postas em relação (ou de anuir com sua igualdade), nesse contexto, não 
há como pressupor uma dimensão valorativa que estabeleça uma graduação entre "saberes maiores" e "saberes menores", tampouco o estabelecimento de certos agentes e instituições como os arautos de um "saber verdadeiro". Trata-se, antes mesmo, de uma práxis que acredita na possibilidade de emancipação pessoa a pessoa, na "comunicação razoável [que] se funda na igualdade entre a estima de si e a estima dos outros" (Rancière, 2011, p.114).

A igualdade das inteligências, assim, não pode ser mensurada com a comparação de repertórios ou de conteúdos próprios aos indivíduos, mas posta em prática a cada vez que se reconhece no outro um igual, ${ }^{2}$ aquele que pode aprender - e ensinar - por si, visto que o que aprende (atualiza) não é um dado ou uma fórmula, mas uma nova forma de se relacionar com o mundo, como presença curiosa e inventiva capaz de articular um fato com o todo da realidade: o que se aprende (e o que se está pronto a ensinar, portanto) é o trajeto da própria emancipação.

Qualquer possibilidade de interação dialógica deve reconhecer como antecedente, assim, a instalação de um dissenso que reconfigure as divisões "dadas" de certa comunidade, suas formas de partilha. É esse o movimento que instaura a representação legítima de uma classe - ou uma parcela - que até então figurava como massa indistinta, participando (tomando parte) apenas na medida de sua conformidade às regras, mas não segundo sua capacidade de enunciação. Isso não significa, como se pode supor de maneira ingênua, que a mera "delegação da fala" àqueles até então privados de expressão articulada seja necessariamente uma ação política. Haverá política onde essa faculdade de enunciação fizer valer uma

2 A alusão a "reconhecer no outro um igual", neste contexto, não remete a um princípio identitário, aquele que fixa um sujeito em posições de pertencimento, a exemplo de raça, crença, situação hierárquica, opções político-partidárias, entre outras tantas. Trata-se, antes, ao que Agamben situa como o ser qualquer, tal qual é ou ainda o qual-quer (aquele que quer, que estabelece uma relação original com o desejo e, assim, pode experimentar, enunciando-se, uma autêntica experiência de si). É a igualdade do ser qual-quer, de ser homem entre homens, "ser gerado a partir da própria maneira de ser" (Agamben, 2013, p.35). 
legitimidade interlocutiva, habilitando um sujeito ou um grupo no espaço de seu discurso.

É esse, acreditamos, o grande desafio de se assumir a interação dialógica como fundamento ético nas práticas extensionistas. Seu reconhecimento, assim como suas possibilidades de emergência, inegavelmente necessários, assumem centralidade na vigente Política Nacional de Extensão Universitária. Mas sua assunção nos fazeres cotidianos das universidades implica o trabalho consciente de reconhecer nos públicos envolvidos nessas ações a dimensão subjetiva que produz saberes legítimos, opera escolhas, constrói e reconstrói realidades.

A necessidade da interação dialógica situa a articulação entre a universidade e os diversos atores e movimentos sociais na perspectiva do acesso mútuo aos ambientes próprios a cada uma dessas esferas. Entretanto, tais relações ainda tendem à manutenção do "cada qual em seu lugar", traduzindo-se em formas de interação protocolares que, reconhecendo os limites de atuação da alteridade, nada mais fazem do que conservar o espaço da identidade, com seus fazeres hierarquizados e a conhecida "ordem das coisas".

Uma prática extensionista radicalmente comprometida com a interação dialógica entre a academia e os movimentos sociais faz redimensionar, consequentemente, o conceito e o papel da própria universidade pública. Sendo também uma parte da sociedade (e não um lugar utópico passível de se esquivar de suas urgências), a universidade não pode se furtar ao reconhecimento das vozes e demandas sufocadas pelas leis do mercado e pelas "políticas" que performatizam a racionalidade operacionalizando a discriminação e a desigualdade sociais. Redimensionar as relações de poder significa antes de tudo instaurar novos horizontes de enunciabilidade.

É, paradoxalmente, autodeterminando-se a acolher o dissenso, redefinindo as distribuições das formas de ver, dizer e fazer, estabelecendo a comunicação entre universos que não reconheciam um ao outro, que a universidade pública poderá começar a cumprir sua vocação cidadã. Trata-se de um trabalho de construção e reconstrução que se efetiva em uma ordem das ficções: 
Ficção não é criação de um mundo imaginário oposto ao mundo real. É o trabalho que realiza dissensos, que muda os modos de apresentação sensível e as formas de enunciação, mudando quadros, escalas ou ritmos, construindo relações novas entre a aparência e a realidade, o singular e o comum, o visível e sua significação. Esse trabalho muda as coordenadas do representável; muda nossa percepção dos acontecimentos sensíveis, nossa maneira de relacioná-los com os sujeitos, o modo como nosso mundo é povoado de acontecimentos e figuras [...]. Os modos da ficção criam assim uma paisagem inédita do visível (Rancière, 2012, p.64-65, grifo do autor).

As formas da ficção representam, pois, uma aventura de possibilidades. Desmobilizam argumentos de autoridade e questionam o "ser assim" do mundo para dar substância a realidades até então imponderáveis. Ao mesmo turno, pressupõem a fabricação (fictio) desse universo em uma dimensão coletiva, povoada por indivíduos igualmente habilitados a tomar parte nessa construção. Pensar a prática extensionista em tal dinâmica exorbita o aspecto de abrir ostensivamente as portas das universidades aos movimentos e atores sociais, ainda que essa etapa seja indiscutivelmente necessária. Não se trata simplesmente de dilatar os limites da inclusão, mas de formular e reformular, em um movimento jamais rematado, a cena comum em que as pessoas atualizam sua condição de sujeitos políticos.

\section{Referências bibliográficas}

AGAMBEN, G. A comunidade que vem. Belo Horizonte: Autêntica Editora, 2013.

BAKHTIN, M. Marxismo e filosofia da linguagem. São Paulo: Hucitec, 2004.

DE PAULA, J. A. A extensão universitária: história, conceito e propostas. Interfaces - Revista de Extensão, v.1, n.1, jul.-nov. 2013. 
FORPROEX. Plano Nacional de Extensão Universitária. Ilhéus: Editus, 2001.

Política Nacional de Extensão Universitária. Manaus: [s.n.], 2012. Disponível em: http://www.renex.org.br/documentos/2012-07-13-Politica-Nacional-de-Extensao.pdf. Acesso em: 11 jan. 2015.

FREIRE, P. Extensão ou comunicação? Rio de Janeiro: Paz e Terra, 1983.

NOGUEIRA, M. D. P. Extensão universitária no Brasil: uma revisão conceitual. In: FARIA, D. S. (Org.). Construção conceitual da extensão universitária na América Latina. Brasília: UNB, 2001.

Políticas de extensão universitária brasileira. Belo Horizonte: UFMG, 2005.

RANCIÈRE, J. O desentendimento. São Paulo: Editora 34, 1995. O mestre ignorante. Belo Horizonte: Autêntica Editora, 2011. O espectador emancipado. São Paulo: Editora WMF Martins Fontes, 2012. 


\title{
3 \\ Cultura Política, MÍDIA E MOBILIZAÇÃo
}

\author{
Paulo Roberto Figueira Leal \\ Rafael do Nascimento Grohmann \\ Rodrigo Souza Silva
}

\section{Introdução}

Iniciado em 2008, o projeto de pesquisa e extensão Comunicação para a cidadania: tecnologias, identidade e ação comunitária, financiado pela Universidade Federal de Juiz de Fora (UFJF) e pela FAPEMIG, tem como objetivo geral a contribuição para a democratização da comunicação e para o exercício da cidadania de estudantes de escolas públicas de bairros periféricos de Juiz de Fora, Minas Gerais.

A estes jovens foram oferecidas atividades em oficinas, conduzidas por professores da Faculdade de Comunicação da Universidade Federal de Juiz de Fora (UFJF) e seus bolsistas de iniciação científica e de extensão, que procuravam estimular maior reflexão dos participantes com relação aos conteúdos provenientes da mídia. Foram seis as oficinas: de novas tecnologias, jornal impresso, rádio, fotografia, TV e cultura política. É a esta última que o presente capítulo se referencia.

A oficina de cultura política buscava refletir mais diretamente sobre o contexto político contemporâneo e o significado dessa instância tão pouco compreendida e explorada por parcelas significativas da juventude. Uma das metas era verificar quais eram, no 
momento de chegada, os valores políticos desses jovens, e o quanto dessas visões decorreria das informações recebidas por eles da mídia (partindo da pressuposição de que os valores hegemônicos seriam majoritários na circulação dos meios de comunicação de massa e, portanto, estariam presentes nas opiniões dos adolescentes).

Paralelamente, objetivava-se efetivar com eles discussões temáticas específicas, relacionadas à política, a partir de valores contra-hegemônicos, de modo a levá-los à reflexão crítica e, se possível, à ação efetiva: a partir das atividades trabalhadas com os jovens, procurou-se conduzi-los não só a repensar as possibilidades de ação política na comunidade e na escola, entre outros espaços, mas a efetivamente terem condições de executá-las.

O presente capítulo apresenta relato dos trabalhos desenvolvidos e os resultados alcançados na oficina. Considera-se que a socialização dessas ações, dilemas, problemas e soluções abre perspectivas frutíferas para outras iniciativas que pretendam trabalhar com jovens em situação de vulnerabilidade social - atores sociais que, mais do que nunca, devem encontrar oportunidades que os auxiliem no processo de se tornarem protagonistas de suas próprias histórias.

Em 2008, a base territorial trabalhada pelo projeto foi a Escola Municipal Santa Cândida, localizada no bairro homônimo da zona leste de Juiz de Fora. As atividades iniciaram-se com dezesseis adolescentes, entre 14 e 17 anos, cursando entre a quinta e a nona séries, dos quais chegaram ao final das atividades sete deles, seis meninas e apenas um menino. Segundo Lahni et al. (2009), o grande número de desistências se deu em razão, principalmente, das premências de inserção de muitos deles no mercado de trabalho, já que o projeto inicialmente não disponibilizava bolsas.

\section{Valores ideológicos e mídia}

Berger e Luckmann (1985) sustentam que a percepção que cada um de nós tem da realidade decorre, fundamentalmente, dos pro- 
cessos de socialização e das interações que desenvolvemos com outros indivíduos e instituições - essas relações comunicativas nos oferecem universos simbólicos compartilhados fundamentais para nossa percepção e atribuição de significado às coisas do mundo e a nós mesmos.

Já Goffman (1974) aponta que os enquadramentos (entendidos como modelos de interpretação e seleção que definem ênfases e exclusões utilizadas para organizar o discurso) constituem recortes culturais cruciais para a organização de nossas visões de mundo. Também o sistema contemporâneo da mídia - tão importante como fonte de informação e transmissão de valores para milhões de cidadãos mundo afora - opera a construção de seus discursos por meios de enquadramentos, como observa Gitlin (1980).

Mas quais são as implicações disso na constituição da visão de mundo dos indivíduos? Num contexto em que, a cada dia mais, a esmagadora maioria das certezas não provém da experimentação direta, porém de informações mediadas pelo aparato da comunicação de massa, é razoável supor que as valorações (explícitas ou implícitas) majoritárias na discursividade da mídia impactam, em alguma medida, as visões daqueles que dependem de modo excessivo - ou exclusivo - dessas fontes para formar juízo sobre a realidade.

Em outras palavras, valores ideológicos hegemônicos na mídia podem ser introjetados, em alguma proporção, por indivíduos e grupos. É preciso ressalvar o sentido que aqui se dá à expressão ideologia. Mais do que mero posicionamento político, trabalha-se com a ideia gramsciana de que "todo homem é filósofo, ou seja, que todo homem manifesta em sua ação - através de sua linguagem, de seu senso comum, de suas crenças etc. - uma concepção do mundo" (Coutinho, 1980, p.83).

No caso específico de visões sobre política que são oferecidas pela comunicação de massa (e que se supõe que possam ser incorporadas por alguns), dada a natureza empresarial dos grandes grupos de comunicação, é razoável afirmar que os valores ideológicos majoritariamente ofertados pelo discurso midiático tradicional 
encontram-se, do ponto de vista da escala entre esquerda e direita, mais à direita do que à esquerda.

Vozes mais céticas à validade dessa escala poderiam perguntar: no momento histórico em que vivemos (pós-derrocada da experiência do socialismo real), ainda é possível falar em identidades ideológicas à esquerda ou à direita? Bobbio (2001) sustenta que sim. Desde a Revolução Francesa, quando as expressões esquerda e direita se popularizaram no jargão político, a dicotomia expressa profundas diferenças de valores.

Mesmo que se leve em conta que a distinção comporta numerosas posições intermediárias, há uma nítida clivagem ideológica sobre a questão da igualdade entre as pessoas. A posição típica de esquerda assenta-se na suposição de que não apenas a causa da desigualdade é majoritariamente social como ela pode ser eliminada (crença de que não partilha a direita). As instâncias coletivas dentre elas o Estado - seriam fundamentais para resolver estes problemas.

Se o discurso hegemônico, portanto, situa-se à direita e se, dentro dele, há uma prevalência da variante liberal, a compreensão da face contemporânea deste discurso engloba fundamentalmente as argumentações teóricas de pensadores liberais do século XX, como Friedrich August Von Hayek (1899-1992). Ele criou um arsenal discursivo baseado, sobretudo, no louvor das ações tomadas por agentes individuais (empresas ou indivíduos), mais eficientes, em sua opinião, do que as engendradas por atores coletivos.

Esta visão de desconfiança em relação às instâncias coletivas mas também às capacidades de intervenção e de regulação da política em geral - é frequentemente expressa pela grande imprensa. Mas até que ponto ela é assimilada e internalizada (consciente ou inconscientemente) por jovens de regiões periféricas, cujo acesso à informação é fortemente limitado por conta de suas condições socioeconômicas? Eles incorporam os valores presentes neste discurso de demonização do Estado - e, por associação deste como centro da atividade política, numa visão simplista, de demonização da própria política? 
Apesar de serem jovens que, mais até do que outros, demandariam a capacidade de organização coletiva para a solução de problemas, eles manifestam-se próximos de uma visão individualista - tal como preconizado pelo ideário liberal? Tendo em mente essas questões, o projeto consistiu no acompanhamento - por meio das metodologias de observação participante, complementada por entrevistas e questionários - das opiniões políticas de jovens juizforanos que participaram da oficina de cultura política.

Em resumo, os pressupostos teóricos iniciais eram: a) visões de mundo sobre a realidade e valorações ideológicas decorrem dos processos de socialização a que indivíduos são submetidos; b) os meios de comunicação passaram, na contemporaneidade, a ser cada vez mais presentes nesses processos de socialização, à medida que constituem a fonte discursiva prioritária (às vezes única) para parcelas da sociedade; c) a mídia representa e vocaliza visões marcadas por valorações ideológicas - e, no caso da grande mídia empresarial, estas marcações encontram-se situadas à direita do espectro ideológico (sobretudo a partir da vertente liberal); d) na leitura neoliberal, representada pelas ideias, por exemplo, de Hayek, as ações individuais são mais valorizadas que as instâncias coletivas; e) jovens de regiões periféricas de Juiz de Fora - por conta de suas condições socioeconômicas - tendem a depender excessivamente das informações que recebem de veículos de comunicação, sobretudo a TV, para formar suas próprias visões sobre o que seja a política; f) dentre essas visões, imagina-se que há uma predominância de concepções simplistas e negativas da política (derivadas de uma visão negativa das instâncias coletivas e do Estado) e uma prevalência de valores individualistas.

Partindo desse circuito lógico como rede de hipóteses, o trabalho da oficina tinha um duplo objetivo: verificar se isso efetivamente acontecia e, em caso afirmativo, apontar se as discussões ali realizadas - baseadas em leituras contra-hegemônicas - poderiam conduzir os jovens à adoção de outras visões e outras práticas no espaço público, mais participativas e colaborativas, entendendo a política a partir dos conceitos de micropoder e micropolítica, de 
Foucault (2005), que estudou os mecanismos de poder a partir das prisões, dos hospícios e do próprio discurso. Portanto, devemos compreender a política como pertencente à "ideologia do cotidiano”, no conceito de Bakhtin (1992), ou seja, fundada na interação, no diálogo e na relação social, atrelados a um contexto. Seguem, adiante, resultados a apontarem se os pressupostos iniciais foram ou não verificados.

\section{A presença da mídia na vida cotidiana e a depreciação da política}

Os resultados dos questionários respondidos pelos adolescentes nos primeiros dias da oficina de cultura política em 2008 e 2009, com um total de 36 respondentes, referem-se a turmas provenientes de bairros distintos que foram atendidos numa ou noutra oportunidade. Os jovens de São Pedro, Dom Bosco, São Benedito, São Sebastião, Santa Cândida e Granjas Betânia tinham, no momento das respostas, entre 14 e 18 anos (com média de 16 anos).

As famílias de todos eles possuíam, no mínimo, um aparelho de televisão, sendo que uma parcela significativa $(27,8 \%)$ possuía três aparelhos de tevê em cores na residência. Além disso, 97,2\% tinham um aparelho de vídeo ou DVD, e a mesma percentagem dispunha de, ao menos, um rádio.

A televisão ainda detinha crucial importância na vida destas pessoas, já que 41,7\% afirmaram utilizá-la como principal veículo para busca de notícias sobre política. No entanto, como já têm apontado outros estudos, a internet vem ganhando importância no cenário. Há de se destacar que 11,1\% afirmaram não procurar em lugar algum notícias sobre política, o que já evidencia, em alguma medida, que a política não instigava a curiosidade de parte significativa destes jovens.

A centralidade televisiva era reforçada pela resposta à questão "horas por dia assistindo à TV": as respostas variaram de duas a treze horas, com média de 3,4 horas por dia. Ficava evidente que 
este meio de comunicação ocupava um espaço central no dia a dia destas pessoas. A maior parte delas $(86,1 \%)$ afirmava gostar do que via, ouvia ou lia, principalmente por ser interessante $(27,8 \%)$, pelo teor informativo (25\%) e pela diversão (22,2\%). Há de se enfatizar que, entre os que não gostavam do que viam, muitos apresentavam como motivo o fato de que as notícias eram ruins.

Com relação ao tipo de programa de que que mais gostavam, os jovens tinham as seguintes opções: novela, telejornal, esportes, humorístico, desenhos e filmes. A maior parte dos pesquisados (41,7\%) assinalou todas ou quase todas as opções - o que evidenciava a preferência por um modelo de TV geralista (Wolton, 2006)-, mas houve preponderância individual da novela, tendo a predileção de 27,8\%.

Sobre o mundo da política, $80,6 \%$ dos pesquisados afirmaram não se interessar pelo tema. A justificativa mais usada, por $25 \%$ dos jovens, era de que a política seria "chata". Igual fatia de $25 \%$ dos respondentes não justificou sua resposta. Outras justificativas dadas foram: "não gosto", "não entendo", "não voto", "porque é só corrupção". Entre os 19,4\% que afirmam se interessar pela área, houve justificativas como: "vou começar a votar", "porque traz conhecimento", "é legal”, "é um meio de expressão”, "para ver se os políticos cumprem as promessas", "para ver ideias novas".

Foi-lhes pedida uma definição de política: 33,4\% não responderam ou não souberam dizer o que ela seria. A definição mais usada era a de política como perda de tempo, em 13,9\% dos casos - um bom indicativo do conceito negativo que eles, em sua maioria, tinham sobre o tema. Outras justificativas foram: "brigas", "eleição”, "corrupção” (que, juntas, somaram 22,2\%).

Poucos respondentes apresentaram visão dissonante desta leitura depreciativa. As seguintes citações configuraram exceções: "direito de votar", "organização social”, "governo", "partidos”, "partidos eleitorais” (expressão que evidenciava a percepção de que os partidos políticos apenas funcionam em época de eleição), "pessoas com poder de melhorar a vida das pessoas", "relação com a vida cotidiana", "responsabilidade", "saber quem cuida da cidade", "tudo que envolve a sociedade". 
Ou seja, por mais que alguns respondentes isolados enxergassem a presença da política na vida cotidiana, a maioria a via apenas na esfera eleitoral, do governo e dos partidos políticos e não em suas próprias vidas. Seria algo que não diz respeito a eles próprios nem trataria de coisas positivas. Na verdade, a maioria dos respondentes afirmava, direta ou indiretamente, querer se distanciar dela.

Na parte final do questionário, foi perguntado se eles tinham opinião formada sobre atores políticos, como algum partido, o presidente Lula e o prefeito da cidade de Juiz de Fora (Alberto Bejani, nas primeiras turmas, e Custódio Mattos, na última). Com relação ao partido político, a maioria $(77,8 \%)$ dizia não ter qualquer opinião formada ou não respondeu. Os partidos foram mencionados por apenas três pessoas, que citaram PT, PSDB e PTB (sendo que o PT foi considerado por duas pessoas). Dois nomes de políticos (Custódio Mattos e Carla Vidal) apareceram como "partidos políticos" em 11,2\% dos casos, o que indica, em certa medida, o fenômeno da personalização da política (Wattenberg, 1991).

No que diz respeito ao presidente, o número de casos sem resposta ainda era grande $(41,7 \%)$, mesmo sendo uma figura com mais visibilidade do que os partidos políticos. O campo semântico ao qual Lula foi mais relacionado era o de "bom presidente", em 30,6\% dos casos. Outros casos isolados: "corrupto", "ladrão", "não gosto de Lula", "não é capacitado" ou "precisa fazer mais" poderiam ser colocados em um campo "negativo", com 14\% dos casos. Ainda apareceram como respostas "PT" e "é o presidente".

Quanto aos prefeitos da cidade, mais uma vez foi predominante a não opinião formada sobre o assunto, o que ocorreu em 33,3\% dos casos. Isso confirmava o distanciamento dos jovens em relação à política, vista negativamente por eles. Em relação ao ex-prefeito Alberto Bejani (que foi eleito pelo PTB em 2004, mas renunciou em 2008 em razão de acusações de desvio de recursos), 16,7\% dos respondentes identificaram Bejani como corrupto, 13,9\% como "safado, cachorro e sem-vergonha", e 5,6\% como "bandido" - corroborando a imagem negativa mostrada pelos jornais. 
As últimas perguntas deste questionário inicial, respondido no primeiro encontro realizado pela oficina em cada turma, abordavam a participação dos jovens em alguma associação, seja ela de bairro, religiosa ou estudantil, por exemplo. Como resultado, $86,1 \%$ responderam negativamente à pergunta, com alguns justificando a não existência de um espaço como esse em seus bairros. Os 11,1\% que responderam "sim" participavam de associações religiosas, o que evidenciou a falta de pluralidade de espaços públicos nos bairros de regiões periféricas da cidade.

Em resumo, os dados revelados pelo questionário inicial reforçavam as hipóteses sobre o perfil dos jovens quando começaram as atividades da oficina: desinteressados por política, percebida por eles como algo limitado (e compreendida apenas em sua dimensão de disputa pelo poder do Estado, considerado negativamente) e não relacionada à vida de cada um. Na verdade, as soluções para seus problemas individuais ou os problemas coletivos de suas comunidades, na visão da maioria, não passavam pela política - ao contrário, demandavam sua negação.

Estas visões, contudo, se mantiveram inalteradas ao longo das discussões? Uma vez instados a refletir sobre questões de política a partir de outro enfoque, durante os módulos, houve mudanças nas visões dos jovens? Para responder a essa questão, um questionário com respostas dissertativas foi aplicado à turma do primeiro semestre de 2008 ao fim das atividades, com perguntas sobre violência urbana, ações políticas e falta de oportunidades culturais e de emprego (os resultados referentes à turma de 2009 estão sendo tabulados e serão apresentados em texto posterior).

As respostas trazem indícios de algum desenvolvimento e maior sofisticação política dos adolescentes. Há de se destacar, no entanto, que somente cinco pessoas responderam às questões, dado o esvaziamento da turma de 2008, que terminou com apenas sete alunos dos dezesseis que iniciaram o ano.

A primeira questão era se problemas como a violência urbana, a dependência de drogas e a falta de oportunidades culturais e de emprego entre os jovens estariam ligadas a causas políticas. Em caso 
afirmativo, quais seriam estas causas. Todos responderam afirmativamente, e a ênfase maior foi na questão do emprego: "com a política podem ser criadas leis a favor da população, como o primeiro emprego", "oportunidades que não são dadas a essas pessoas, como um emprego digno, uma moradia", "em uma entrevista para emprego só será selecionada uma pessoa, e as causas são a falta de investimento para poder mudar esses problemas".

Como podemos observar, a falta de verbas e investimentos nestas áreas eram problemas destacados, "fazendo com que as pessoas sejam levadas a arrumar dinheiro de outra forma", "o mundo em que vivemos tem muita corrupção, e os nossos governantes não fazem o que realmente deve ser feito para melhorar e resolver estes problemas, surgindo, assim, a desigualdade e os problemas em comunidades carentes".

Após o diagnóstico de tais problemas como causas relacionadas ao mundo da política, a segunda questão indagava: "quais são as ações políticas que podem ser desenvolvidas por você para lutar contra esses problemas?". Eles destacavam o grêmio estudantil, a associação do bairro, eventos culturais, palestras, conscientização dos problemas por meio da divulgação de folhetos, debates entre os jovens, criar uma ONG.

Ressaltavam também a importância do voto e da televisão como formas de protesto. Um dos jovens diz ainda que "não saberia organizar uma ação política", mas via que as pessoas às vezes faziam manifestações, não sabendo ele, no entanto, se os resultados eram positivos. Trata-se do caso mais descrente entre os jovens com relação à ação política. Porém mesmo aí fica evidente a percepção do papel estratégico da comunicação nas lutas políticas - e da necessidade de que se desenvolvessem políticas de comunicação capazes de dar vozes a todos.

A terceira questão abordava em quais espaços de atuação política o jovem poderia se envolver para melhorar sua vida e das pessoas ao seu redor e o que poderia ser feito nesses espaços. A maioria apontava a importância da associação de bairro e da escola, por meio do grêmio estudantil, com um exemplo de grupo de jo- 
vens para promover espaços culturais, palestras, músicas, debates e festas.

É preciso ressaltar que este foi o único exemplo prático dado pelos respondentes daquilo que poderia ser feito num espaço de atuação política - os outros apenas explicitaram os locais que podem servir para a atuação política. E um dos pesquisados foi especialmente pessimista: "em nenhum, pois não sei que espaços são esses e não entendo o bastante de política para me envolver em um espaço de atuação para melhorar a vida de outras pessoas".

Ou seja, apesar de a maioria deles ter, ao longo da oficina, percebido que a política está relacionada aos seus problemas cotidianos (e que não se resume à disputa pelo poder do Estado nem deve ser negada), traços ideológicos que reiteravam uma visão de mundo marcada pelo individualismo ainda apareceram fortemente em respostas como essa. Mas tais respostas aos questionários talvez sejam insuficientes para dar conta das valorações ideológicas profundas e das mudanças ocorridas ao longo da oficina. Abordagens interpretativas da própria relação estabelecida nos encontros constituem evidências úteis para extrair inferência. É o que segue.

\section{Como levar os jovens à reflexão crítica?}

Uma vez que os encontros da oficina tinham como objetivo discutir com os jovens as várias formas pelas quais poderiam agir politicamente em diferentes âmbitos da sociedade (a demonstrar que política não é uma atividade restrita aos governantes), foram escolhidos temas que, de alguma maneira, tivessem relação com o cotidiano de suas comunidades. Tratou-se de questões como: violência, racismo, falta de oportunidades, sexualidade, gênero, eleições, participação estudantil, território e espaço público, e juventude e sua representação nos meios de comunicação.

Na perspectiva de extrair informações sobre as concepções dos jovens para além daquilo que eles responderiam nos questionários aplicados, os bolsistas do projeto estavam instruídos a observar as 
reações dos adolescentes enquanto os debates eram feitos, com base nos pressupostos e ferramentas de observação participante. Por causa da complexidade dos temas tratados (e também em razão da resistência que os adolescentes tinham em relação ao tema), optou-se pela diversificação metodológica na condução dos encontros.

Apesar da valorização da produção oral - seja pelas exposições iniciais daquele que eventualmente conduzia a dinâmica, seja pelo estímulo à verbalização dos jovens -, outras atividades foram escolhidas para incentivar a movimentação e otimizar os níveis de participação. A escolha temática atendeu ao critério de trazer à tona assuntos relacionados à vida cotidiana.

Dessa maneira, no primeiro encontro da turma do segundo semestre de 2008, por exemplo, cujo tema era violência, a metodologia escolhida foi a oferta de um vídeo. Dada a existência, entre eles, de uma cultura audiovisual - e a centralidade da TV em suas vidas cotidianas era um indicador disso -, optou-se por exibir um trecho do documentário Notícias de uma guerra particular, de João Moreira Salles e Kátia Lund, de 1999.

O filme retrata o cotidiano dos moradores e traficantes do morro da Dona Marta, no Rio de Janeiro, por meio de entrevistas com pessoas que se encontravam, de alguma forma, próximas à rotina do tráfico de drogas. O objetivo era estabelecer comparações entre o que era mostrado pelo documentário e o que os jovens presenciavam no cotidiano, assim como fazê-los refletir sobre a forma naturalizada (e usualmente acrítica) com que viam a violência.

Além disso, outras formas de violência que não a física foram abordadas, como a moral, a psicológica e a simbólica. Tentou-se, também, estimular uma visão crítica dos meios de comunicação, discutindo sobre como o bairro deles era representado pelos telejornais da cidade.

A participação dos jovens foi surpreendente. Eles relataram várias experiências que tiveram ou que presenciaram em relação aos vários tipos de violência, como brigas, abordagens policiais, ocasiões em que sofreram discriminação ao entrarem em lojas. Além disso, disseram gostar bastante de ouvir músicas, principalmente 
as dos gêneros funk, hip-hop e rap, pois se sentiam representados nas letras.

Assim, no segundo encontro com essa turma, optou-se por abordar o tema racismo a partir de duas músicas: um samba, "Canto das três raças", de Clara Nunes, e um rap, "Racismo é burrice”, de Gabriel Pensador. Buscou-se discutir a origem histórica do racismo e a participação política e cultural que os grupos excluídos têm na sociedade, sobretudo no que se refere aos negros. Os jovens refletiram também sobre como o negro é representado pelos meios de comunicação, principalmente nas novelas, nas quais quase sempre estão em menor número e exercendo papéis secundários. Por fim, a discussão chegou à politização da questão do racismo e do preconceito nas escolas.

O tema do encontro seguinte foi a falta de oportunidades, envolvendo as distintas classes sociais, e as diferenças de empregabilidade. Abordou-se a educação e a acessibilidade dos jovens em relação às escolas. Para isso, foi escolhido um trecho do documentário Pro dia nascer feliz, de João Jardim, como forma de iniciar a discussão. O filme aborda a realidade do sistema escolar brasileiro ao entrevistar alunos de 14 a 17 anos, de diferentes classes sociais, e professores de escolas públicas e particulares.

Procurou-se fazer os jovens refletirem acerca de seu próprio ambiente escolar, dos problemas e de como resolvê-los. Além disso, discutiu-se sobre espaços culturais dentro das escolas, como atividades envolvendo música, esportes, e sobre formas de participação dos alunos, como grêmios estudantis.

Os temas sexualidade e gênero foram tratados em um mesmo encontro. A metodologia escolhida para esta oficina foi o estímulo à produção criativa dos jovens: eles montaram painéis com imagens publicitárias, de forma a incentivar a consciência crítica em relação a estereótipos femininos e masculinos em diversos âmbitos que são frequentemente veiculados nos meios de comunicação. Várias imagens relacionadas aos temas foram recortadas de revistas e jornais.

Em seguida, foi pedido que escolhessem as imagens que lhes chamassem mais atenção. Logo após, debateu-se sobre o que os 
motivou a escolher tais fotos, problematizando os elementos retratados. Entre os temas discutidos estavam os papéis sociais comumente associados ao homem e à mulher, questões envolvendo homossexualidade, preconceito e formas de combatê-lo.

Como política envolve também a questão dos representantes que escolhemos pelo voto e uma vez que estávamos em época de eleições para a prefeitura da cidade, o tema do encontro seguinte foi o cenário eleitoral. Depois de responderem a algumas questões, foram exibidos programas de TV do horário de propaganda eleitoral gratuita, de maneira a fazer que apontassem o que estava proposto pelos candidatos. No entanto as críticas feitas pelos jovens centraram-se nos próprios programas, considerados "chatos", e não em relação ao conteúdo das propostas.

As opiniões verbalizadas pelos adolescentes sobre os candidatos provieram mais de imagens e informações externas aos programas, como boatos e históricos, do que de alguma reflexão suscitada pelos próprios programas. Os elementos de despolitização e de não percepção das questões ideológicas de fundo revelavam-se mais uma vez: a demonização do poder público foi outro traço perene - bem em conformidade com uma identidade ideológica liberal, reverberada pela mídia, que sistematicamente associa tudo que é público ou estatal à ineficiência.

No encontro que abordou o tema participação estudantil, foi utilizada outra plataforma de comunicação, a internet. O objetivo era incentivar os jovens a realizarem pesquisas sobre assuntos diversos e mostrar que a rede tem muitas possibilidades além de sites de relacionamento e programas de mensagens instantâneas. Além disso, preferiu-se ampliar a discussão para movimentos sociais, nos quais a participação estudantil estaria incluída. Para tal, algumas palavras foram sorteadas entre os jovens. Entre elas, "movimento estudantil", "movimento negro", "movimento feminista", "movimento dos sem terra" e "grêmio estudantil".

Os jovens se organizaram em duplas, cada uma compartilhando um computador e tendo a meta de pesquisar sobre o movimento sorteado. Depois, o grupo se reuniu em uma roda para partilhar as 
pesquisas realizadas, opiniões sobre os movimentos e ideias para criação de novos grupos para lutar por causas distintas.

$\mathrm{Na}$ oficina seguinte, o tema foi espaço público e privado. Neste encontro, cujo objetivo era a desmistificação da imagem de ineficiência e de mau funcionamento que comumente é associada à palavra "público", debateu-se a necessidade de valorizar a ação coletiva em detrimento de uma perspectiva individualista. Para isso, houve uma breve discussão sobre quais espaços seriam públicos e quais seriam privados, a diferença entre os conceitos, como a sociedade se relacionava com o espaço público, além de possíveis formas de atuação. Os jovens associaram espaço público a um lugar em que todos podem entrar e estar; e espaço privado como algo pertencente a alguém, só sendo possível a entrada quando permitida.

Posteriormente, levantaram questões sobre espaços comerciais e igrejas, refletindo sobre se estes seriam públicos ou privados. Em seguida, foi pedido que fizessem cartazes com desenhos, colagens e frases sobre espaços públicos, envolvendo problemas e possíveis soluções. A dificuldade inicial de que eles percebessem a dimensão do que seja público provavelmente revela a marca ideológica mais nítida a demonstrar-se como estruturante de suas valorações e visões de mundo: o individualismo.

O último tema abordado foi a relação entre juventude e os meios de comunicação. Propôs-se aos jovens que fizessem um jornal em forma de mural para exposição na mostra que finalizaria o projeto. Assim, puderam refletir e discutir sobre os mais variados assuntos abordados durante todo o desenvolvimento da oficina, relacionando-os com os meios de comunicação. Foram utilizados trechos de músicas, poesias, imagens, notícias, frases e desenhos. O mural foi exibido durante uma mostra que também expôs os trabalhos desenvolvidos em todas as outras oficinas.

\section{Considerações finais}

As hipóteses iniciais se confirmaram: uma vez tendo formado juízo sobre política a partir dos enquadramentos dados pela 
comunicação de massa - que normalmente a associam apenas à disputa pelo poder e aos eventuais escândalos dela decorrentes -, as visões dos adolescentes eram marcadas, ao iniciarem a oficina, por uma leitura simplista e negativa da política. Eles não percebiam as possibilidades de atuação política fora dos espaços eleitorais, nem conectavam a política às possibilidades de resolução de seus problemas individuais ou coletivos.

As marcas do individualismo e da demonização das esferas públicas de atuação (em especial do Estado) - traços relevantes da identidade ideológica liberal, hegemônica nos discursos midiáticostambém apareceram com intensidade nas falas e textos produzidos pelos adolescentes, sobretudo nos momentos iniciais.

Contudo, mesmo longe de um patamar que possa ser considerado ideal, o percurso da oficina oferece evidências de que processos de reflexão e de estímulo à ação no espaço público ali se iniciaram. Além dos indicativos já extraídos das respostas dos jovens nos questionários e de suas participações nos encontros, dados posteriores indicam as potencialidades de ações como esta.

$\mathrm{O}$ fato de que algumas adolescentes, a partir da oficina, empreenderam esforços para organizar um grêmio (até então inexistente) em sua escola, ou de que outras tenham tomado a iniciativa de procurar a associação de moradores de seu bairro para instalar uma Comissão de Juventude, apontam para a possibilidade de que muitos jovens tenham caminhado em direção à politização.

Entende-se aqui politização por capacidade de reflexão, de escolha autônoma, de organização coletiva e de interferência na realidade. Se esta combinação se impuser e for capaz de oferecer contrapesos à posição hegemônica, cria-se uma potencialidade crítica de reação aos discursos que ocultam suas dimensões ideológicas - e todo discurso é ideológico. Deste modo, a percepção de que a vida no espaço público é capaz de impactar cada vida privada é, em grande medida, um avanço que conduz os jovens à atuação política, mais do que à mera replicação de valores naturalizantes do individualismo e da inação. 


\section{Referências bibliográficas}

BAKHTIN, M. Marxismo e filosofia da linguagem. São Paulo: Hucitec, 1992.

BERGER, P.; LUGKMANN, T. A construção social da realidade. Petrópolis: Vozes, 1985.

BOBBIO, N. Direita e Esquerda. São Paulo: Unesp, 2001.

COUTINHO, C. N. Fontes do pensamento político. Rio de Janeiro: L\&PM, 1980.

FIORIN, J. L. Linguagem e ideologia. São Paulo: Ática, 2004.

FOUCAULT, M. Microfísica do poder. Rio de Janeiro: Graal, 2005.

GITLIN, T. The whole world is watching. Berkeley: University of California Press, 1980.

GOFFMAN, E. Frame analysis. New York: Harper and Row, 1974.

HAYEK, F. A. V. O caminho da servidão. Rio de Janeiro: Instituto Liberal, 1990.

LAHNI, C. (Coord.); COUTINHO, I.; FELZ, J.; FUSER, B.; LEAL, P. R. F.; MUSSE, C.; REZENDE, R. Projeto de extensão da UFJF trabalha educomunicação com adolescentes de escola pública. Anais do 4 - Congresso Brasileiro de Extensão Universitária. Dourados: CEBEU, 2009.

WATTENBERG, M. The rise of candidate-centered politics. Cambridge: Harvard University Press, 1991.

WOLTON, D. Elogio do grande público. São Paulo: Ática, 2006. 


\section{4 \\ MAPEAMENTO dOS ARRANJOS \\ PRODUTIVOS LOCAIS INTENSOS DE \\ CULTURA: TECNOLOGIAS SOCIAIS PARA \\ A ADOÇÃO DE POLÍTICAS PÚBLICAS \\ INCLUSIVAS NAS CIDADES}

Juarez Tadeu de Paula Xavier

\section{Introdução}

A cidade de Bauru está localizada em uma região concentrada, com convergência de tecnologias analógicas e digitais. O território é ocupado por arranjos produtivos locais intensos de cultura (ApliC) subalternos, produtores de conteúdos, nas esferas da economia criativa: artes, mídias, patrimônio histórico material e imaterial e inovações técnicas e funcionais. Essas características dão à localidade potencial de cidade criativa, com núcleos de produção de conteúdo, redes de conexão, trocas de experiências, agentes organizados em cadeias criativas e produtivas capilarizadas e disseminadas. A cidade é um laboratório de estudo das experiências em comunicação social: dos mecanismos de gestão da informação, dos agentes produtores de conteúdo e dos recursos disponíveis no território. O mapeamento desses arranjos favorece a produção de conhecimento e a elaboração de políticas públicas de inclusão dos segmentos inventivos, localizados em áreas vulneráveis.

A configuração dessa cartografia é o objetivo do Núcleo de Estudos e Observação em Economia Criativa (NeoCriativa), projeto de extensão universitária vinculado ao Laboratório de Estudos em Comunicação, Tecnologia e Educação Cidadã (Lecotec). Ações 
culturais de extensão, projetos de iniciação científica, trabalhos de conclusão de cursos e parcerias são os dispositivos articulados pelo núcleo para a coleta e sistematização de informações. O conceito de círculo de cultura - ações dialogadas com a comunidade - é sua linha de conduta para o mapeamento do território e subterritórios criativos: prospecção, análise, reflexão, projetos compartilhados e colaborativos. Nesse processo, mapearam- $\mathrm{se}^{1}$ a cobertura jornalística sobre economia criativa, os territórios e subterritórios de música independente, os mecanismos de gestão das organizações socioculturais resilientes, e as inovações de comunicação de produtores de conteúdos. Mapeiam-se as tradições imateriais de povos originais e os arranjos de criação, desenvolvimento e distribuição de jogos independentes. Mapear-se-ão as raízes afrodescendentes do território, os grupos de capoeira, os times de futebol amador, as baterias das escolas de samba e as organizações e equipamentos de direitos humanos de atenção à criança e ao adolescente em situação de risco. A meta é colocar à disposição do poder público local e dos agentes produtores de conteúdos informações estratégicas, capazes de orientar a adoção de políticas públicas favorecedoras da inclusão dos segmentos sociais vulneráveis.

\section{Narrativas reversivas e cidadãs}

O mapeamento dos Arranjos Produtivos Locais Intensos de Cultura (ApliC) $)^{2}$ é uma ferramenta de planejamento estratégico para a prospecção das experiências realizadas no segmento da economia criativa nas regiões concentradas. Permite a identificação dos vetores da economia criativa, dos agentes criativos envolvidos em sua inovação, dos recursos mobilizados no território, da ex-

1 O NeoCriativa iniciou seu processo de prospecção no primeiro semestre de 2011 e foi cadastrado na Pró-Reitoria de Extensão em 2012.

2 O NeoCriativa tem como inspiração o conceito de "Círculo de Cultura", desenvolvido pelo educador Paulo Freire (1967, 1987, 2006). 
tensão e da capilaridade das cadeias criativas e produtivas do segmento. Os dados são colhidos pelas pesquisas realizadas no âmbito da graduação e organizados pelas plataformas das redes sociais e softwares livres. ${ }^{3}$

A conformação das redes digitais criou a ecologia virtual necessária para o levantamento georreferenciado dessas informações, base da elaboração de políticas públicas (Turino, 2010) para esse segmento social, que articula a cadeia criativa e produtiva da cultura nos territórios (Plano Nacional de Cultura, 2008).

O objetivo do mapeamento é ampliar a compreensão sobre esses espaços, estudar os impactos das políticas públicas de acesso à rede mundial de computadores nas comunidades em condições vulneráveis, e conhecer o processo de apropriação e mobilização das tecnologias digitais para a produção de conteúdos pelas comunidades das periferias (Xavier; Xavier, 2012).

A erupção desse cenário alterou as bases de produção de conteúdo, relativizou a ação das mídias corporativas e criou uma esfera pública de troca de informação, que ampliou a cognoscibilidade do território e deu as condições para a ruptura com o "discurso único", e para a articulação de projetos possíveis e favorecedores da inclusão (Santos, 2001), com novas narrativas reversivas e cidadãs.

\section{Ecologia digital e a desigualdade no território}

As regiões concentradas de um território têm densidade tecnológica, impulsionadoras da articulação dos Arranjos Produtivos Locais Intensos de Cultura (ApliC). Em tais espaços desenvolvem-se processos com complexos mecanismos disruptivos, que criam assimetrias sociais: desigualdades na distribuição e no acesso aos bens, sistemas e serviços culturais (Santos; Silveira, 2001).

3 Trabalhos de conclusão de curso, projetos experimentais, prospecção de projetos, parcerias com o poder público local e projetos de pesquisa em iniciação científica (FAPESP). 
Essas bacias tecnológicas concentram-se nas áreas de maior densidade técnica, de aplicação de políticas públicas e de formação especializada nas diversas áreas de produção de valores intangíveis, campo da economia criativa.

O processo redefine as formas de ocupação do território. Nele amplia-se a descentralização da produção industrial e emergem novos modelos organizativos e polos avançados na produção. Estimula-se a especialização comercial e dos serviços oferecidos, com a massificação ampliada e capilarizada das tecnologias produtivas. É efetuada uma reorganização das estruturas de produção, com a intensa divisão territorial do trabalho, que se aprofunda nas áreas de densidades técnicas (Santos; Silveira, 2001).

A despeito da assimetria na distribuição dos recursos (materiais e imateriais) pelo território, o processo não impede que os objetos e ações modernizantes tendam a concentrar-se em certos pontos geográficos, nas áreas especializadas e de novas formas de produção (produtos, processos e serviços).

Nesse cenário líquido e com alto grau de fluidez (Bauman, 2012), a entrega de novos serviços impõe a necessidade de novos dispositivos técnicos e operacionais enraizados pelo território, e assimilados pelos segmentos sociais implicados por esse processo (Xavier, 2009).

A região concentrada forma uma cápsula de informação de criatividade. Esse bolsão de inovação e inventividade concentrado em uma faixa territorial organiza um horizonte de possibilidades, onde emergem arranjos produtivos locais, com ateliês criativos e produtivos, a formação dos corredores de conexões entre essas unidades nucleares e o planejamento para a implantação de políticas públicas favoráveis ao processo.

\section{Arranjos e sistemas produtivos locais: da pulverização à organização}

Nos estudos e pesquisas sobre economia criativa (Unctad, 2010; Reis Velloso, 2008; Pochmann, 2008) ganhou relevo a importância 
dos aglomerados de produção e criação (clusters) para o desenvolvimento econômico e social, com foco na inovação, ${ }^{4}$ passando a ser referência internacional como modelo de organização criativa e de tecnologia de ponta. Nesses centros de criação e inovação, estimula-se a conexão com empresas, centros universitários de pesquisa e coletivos culturais produtores de conteúdo. Os arranjos locais articulam áreas de design, desenvolvimento, produção, experimentação, distribuição, consumo e fruição de produtos, serviços e processos criativos. São laboratórios experimentais, centros de inovação e inventividade, enraizados no território (Azevedo, 2008).

Segundo os estudos sobre arranjos e sistemas produtivos locais (Cassiolato, 1995), para que esses aglomerados cheguem à excelência é necessário o reconhecimento de que a inovação e o conhecimento gerado não são fenômenos isolados. Constituem os aspectos centrais da dinâmica e do desenvolvimento dos segmentos produtivos, das organizações, das instituições e dos coletivos culturais.

Há distinções entre arranjos produtivos locais e sistemas produtivos locais. Os arranjos são aglomerações produtivas em que os agentes pouco interagem. Suas relações têm baixa densidade sinérgica e são pontuais, comuns na articulação de conteúdos das mídias radicais (Downing, 2002). Já os sistemas caracterizam-se por interações sistêmicas amadurecidas e desenvolvidas - núcleos de produção conectados, cadeias criativas e produtivas articuladas e planejadas, mecanismo de distribuição colaborativo e sinergia na distribuição para o consumo e fruição (Cassiolato; Szapiro, 2002). Arranjos e sistemas formam chassis espalhados pelo território, com capacidade para a produção de conteúdo e informação.

Nesse cenário, o fenômeno cultural mais significativo das últimas décadas foi a apropriação desses complexos modelos de criação e produção de conteúdo pelos coletivos culturais, articulações em redes e suas implicações políticas e sociais (Vainer, 2014).

4 Vale do Silício nos Estados Unidos da América: APL de inovações tecnológicas; Bollywood na Índia: APL do novo cinema indiano (British Council, 2010). 


\section{Região concentrada e a economia criativa}

A ecologia produtiva das regiões concentradas propicia o desenvolvimento dos projetos em economia criativa. A legislação, infraestrutura, expansão dos serviços, formação de agentes criativos e a instalação de equipamentos sociais formam os bolsões inventivos para as atividades de criação e execução de produtos, processos e serviços culturais.

No modelo de indústrias criativas da Conferência das Nações Unidas sobre Comércio e Desenvolvimento (Unctad, 2010) há quatro grupos que ordenam as diversas linguagens e atividades culturais em economia criativa: patrimônio cultural, artes, mídias e criações funcionais (Ministério da Cultura, 2008; 2011). O modelo da Unctad (Oliveira; Araujo; Silva, 2013) tem as melhores condições para os estudos e mapeamento dos Arranjos Produtivos Locais Intensos de Cultura.

Nos territórios criativos concentram-se ateliês produtivos dos quatro grupos em economia criativa, os subterritórios dessas linguagens artísticas e atividades culturais (rock, samba, funk, rap, grafite, dança, teatro de rua), as redes de conexões capilarizadas (cadeias produtivas e criativas, analógicas e digitais), e a presença de políticas públicas pontuais (verticais e horizontais), de atendimento das demandas sociais, que estimulam o surgimento e a institucionalização dos territórios e subterritórios criativos: bairros, polos produtivos, cidades, bacias, coletivos culturais, grupos de estudos e pesquisas com ações extensionistas e corredores digitais.

Essas ilhas criativas conectadas potencializam os projetos geradores de trabalho, emprego e renda, conforme as pesquisas e estudos sobre a potencialidade da economia criativa (Furtado, 2013; Ministério da Cultura, 2008; 2011; Caiado, 2011; Unesco, 2009).

O mapeamento de tais redes é uma ferramenta de planejamento estratégico das atividades e elaboração de políticas públicas, para os ApliCs e a ação cidadã nas periferias das grandes e médias cidades brasileiras. 


\section{NeoCriativa e o mapeamento do território criativo}

O Núcleo de Estudos e Observação em Economia Criativa organiza informações georreferenciadas dos ateliês criativos (unidades criativas e produtivas), em suas múltiplas linguagens - música, teatro, dança, inovações técnicas e processuais -, e a formação de seus territórios e subterritórios criativos: identificação das unidades de criação, observação das cadeias produtivas pulverizadas pelo território e acompanhamento das políticas públicas culturais e suas implicações sociais.

Atento à necessidade do diálogo na e com a realidade dos agentes criativos dos ApliCs, o NeoCriativa caracteriza-se como um "círculo de cultura": espaço dialógico, de pronunciamento da leitura de mundo e problematizador para a construção do conhecimento coletivo que possibilita a intervenção criadora e recriadora do sujeito criativo que, por meio do trabalho, é capaz de alterar a realidade e produzir cultura (Freire, 1967, 1987, 2006).

O procedimento assegura a realização do mapeamento dialógico: "o diálogo não existe num vácuo político", mas configura-se em "uma espécie de postura necessária na medida em que os seres humanos se transformam cada vez mais em seres criticamente comunicativos" (Freire, 1987, p.96).

O lócus para a observação são os espaços de produção de conteúdos culturais, agrupados pelos projetos de conclusão de curso, iniciação científica, e articulados pelas ferramentas digitais mobilizadas pelo NeoCriativa. Para organizar os dados compilados, desenvolveu-se o conceito de Arranjos Produtivos Locais Intensos de Cultura (ApliC), e a criação de uma base de dados georreferenciados, alicerçada nas ferramentas das redes sociais.

A metodologia parte da observação empírica, da submissão dos dados coletados à avaliação conceitual e do retorno para a observação crítica da realidade factual, do território e seus ApliCs (processos, pessoas e recursos). 


\section{Território criativo de Bauru: laboratório experimental em economia criativa}

A economia criativa é uma das áreas de maior nível de desenvolvimento, no campo da nova economia. Ela se articula em quatro grandes áreas de produção: patrimônio histórico (cultura, tradições, oralidade), artes (plásticas e cênicas), mídias (impressas, eletrônicas e digitais) e produções criativas funcionais (publicidade, design, arquitetura). Seu centro de gravidade são a articulação de economia, tecnologia e cultura e a mobilização da cultura em três dimensões: cidadã, simbólica e geradora de renda e trabalho. O NeoCriativa prospecta essas áreas dos pontos de vista técnicos, estéticos, funcionais e deontológicos. Suas ações visam articular o ensino, com a inovação de práticas e conteúdos críticos; a pesquisa, pelo levantamento de dados e informações sobre a economia da cultura na cidade; a extensão, colocando à disposição dos segmentos sociais e grupos culturais subalternos informações de gestão de processos, pessoas e recursos tangíveis e intangíveis; e a gestão, com a inovação em organização de serviços e processos culturais.

As pesquisas do Núcleo de Observação e Estudos em Economia Criativa (Xavier, 2014a; Xavier, 2014b) sinalizam que o município é uma cidade criativa. Nela convergem as principais características fundamentais para essa condição: existência de subterritórios criativos de diversas linguagens e manifestações culturais, articulados em um território; conexões dos variados arranjos produtivos e criativos da cidade, em diversos estágios de organização, e a adoção de políticas públicas pontuais para tanto.

A cidade conta com cadeias produtivas ativas na produção musical, como o arranjo articulado em volta do samba. ${ }^{5}$ É também o centro do debate do hip-hop no interior, e possui artistas de expressão regional, além de uma cena musical independente e constante.

5 O Sambódromo de Bauru foi o segundo construído no país e é um dos maiores polos da cultura do samba do interior do estado de São Paulo. 
O subterritório do grafite está espalhado em pontos estratégicos, e o teatro é ponto de articulação de eventos nacionais e internacionais e de experimentações em formatos e linguagens. A cidade tem espaços permeados por história e diversidade, como o conjunto arquitetônico e técnico da estação ferroviária, que abarca enredo e identidades construídas em volta das linhas férreas, tribos indígenas, comunidade afrodescendente ativa e culturalmente presente, comunidades estrangeiras, eventos culturais e incentivos de políticas públicas, nos vetores da economia criativa.

$\mathrm{Na}$ cidade há cadeias criativas que fazem a gestão de processos (desenho de uma ação articulada no campo da cultura, como o conselho de cultura, e construção de políticas públicas), gestão de pessoas (universidades com cursos criativos, organizações culturais públicas e privadas, espaços culturais consolidados nas periferias, e coletivos culturais em diversas linguagens), e a gestão de recursos (existência de recursos públicos e privados, digitais e analógicos). O território conta com todos os principais eixos estratégicos da economia criativa: subterritórios da mídia, das artes, do patrimônio histórico e das inovações técnicas e funcionais.

A área concentrada da cidade - sobreposição de próteses analógicas e digitais - é um laboratório experimental para projetos e ações em economia criativa: mapeamento dos arranjos e cadeias produtivas de cultura; definição da identidade cultural dos birôs criativos da cidade; organização de eventos facilitadores das conexões no e do território criativo, e mobilização para a elaboração de políticas públicas que atendam as necessidades dos segmentos subalternos (Gramsci, 1989) dos subterritórios - formados por cadeias de produção e criação - e do território criativo da cidade.

O reconhecimento do município como um território criativo e a criação de políticas públicas consistentes têm como pressupostos a sistematização e mensuração dos dados sobre essa nova modelagem de organização, pouco estudada na cidade, mas que se mostra capaz de fomentar a economia e a inclusão social e criar redes entre os arranjos produtivos locais intensos de cultura, vinculados às manifestações subalternas. 


\section{Com e para a comunidade}

O NeoCriativa adotou a metodologia dos "Círculos de Cultura", conforme conceituado por Freire (1967, 1987, 2006): a) leitura da realidade, pelo mapeamento dos arranjos produtivos e das cadeias criativas de cultura; b) reflexões críticas, a partir de reuniões semanais para planejamento, balanço e correção; e c) intervenção, ${ }^{6}$ com a consultoria à Secretaria de Cultura do município e às organizações sociais.

Com a sistematização da metodologia dos Círculos de Cultura e o estudo do espaço como território criativo, o projeto se divide em três fases: consolidação conceitual, definição dos mecanismos de capturação de dados e informações e organização do mapeamento georreferenciado das cadeias produtivas de cultura. Este último é pautado por técnicas desenvolvidas em um projeto piloto, em que o NeoCriativa mapeou os subterritórios criativos dentro do campus da Universidade Estadual Paulista "Júlio de Mesquita Filho", perfilando-os a partir de uma estrutura de análise baseada na técnica dos "elementos da notícia". ${ }^{7}$ Para a execução do mapeamento, o núcleo faz a observação do fluxo de produção dos arranjos produtivos, in loco, junto de análise quantitativa e qualitativa, para a captação, sistematização e mensuração dos dados em encontros semanais de avaliação e feedback, com a finalidade de desenvolver redes capazes de contribuir com a elaboração de políticas públicas para o setor da Cultura - Plano Municipal de Cultura (PMC).

\section{Considerações finais}

O mapeamento em curso indica a existência de um território criativo, composto por subterritórios de várias linguagens e ati-

6 Grêmio Recreativo Cultural Escola de Samba (GRCES) Coroa Imperial, projeto cultural "Periferia Legal", secretaria de Cultura do Município de Bauru, Ponto de Cultura "Acesso Hip Hop", coletivo cultural "Fora do Eixo" e Associação de Moradores do Núcleo Residencial Geisel.

7 Os elementos da notícia são: quem, quê, quando, onde, porquê, como e consequências, sintetizadas na fórmula: $3 \mathrm{Q}+\mathrm{O}+\mathrm{P}+2 \mathrm{C}$. 
vidades artísticas e culturais, em todos os vetores da economia criativa: artes, mídias, patrimônio histórico e inovações técnicas e funcionais.

Há a organização dos ateliês de criação e produção, como os grupos de teatro, dança, música, hip-hop, grafite e bandas de música independente; conexões entre os subterritórios, por meio dos encontros regionais, das atividades de formação cultural e intervenções culturais nas comunidades; e uma incipiente política pública, que dá sustentação à esfera pública precária de segmentos sociais subalternos, com a aderência ao Plano Nacional de Cultura, formação do Conselho Municipal de Cultura, esboço de "conta-satélite" para a mensuração da economia da cultura na cidade e organização das conferências municipais de cultura.

São tênues, frágeis e pontuais as ações institucionais, sejam públicas, sejam privadas, de organização cultural do espaço, dos agentes criativos envolvidos nesse processo (criadores, formuladores, executores, artistas, críticos, financiadores), das instituições de formação cultural, como as faculdades, universidades, instituições de ensino, organizações ligadas a atividades socioculturais, e dos recursos materiais e imateriais envolvidos na criação, planejamento, execução, distribuição, consumo e fruição.

Entretanto, o mapeamento em curso, como ferramenta estratégica de organização, poderá fornecer informações capazes de contribuir com a organização do território e subterritório criativos, para a elaboração de políticas públicas que atendam à demanda da sociedade, para a prospecção, identificação e fortalecimento das identidades e vocações do território, a fim gerar renda e trabalho, nas dimensões indicadas pelo Plano Nacional de Cultura: simbólica, social, cultural, econômica e inclusiva.

O mapeamento - processo permanente, contínuo e colaborativo - das atividades culturais, baseado na ecologia digital (redes sociais capilarizadas), colocará à disposição dos agentes culturais públicos e privados informações estratégicas para o desenvolvimento de ações consistentes, capazes de estimular a transformação dos Arranjos Produtivos Locais Intensos de Cultura (ApliCs) em 
Sistemas Produtivos Locais Intensos de Cultura (SipliCs), condições para a emergência das cidades criativas.

Com as novas ações focadas na inclusão, em especial a adoção dos pontos de cultura - estações dotadas de hardware e software, com corpo técnico de orientação -, o cenário começa a mudar. Surgem coletivos de cultura de múltiplas linguagens: música, artes plásticas, dança, teatro, literatura e produção audiovisual.

O hip-hop, forma de manifestação cultural da juventude negra e pobre da periferia, foi um ponto de referência importante dessa transição, por articular linguagens (rapper, break, b.boys/b.girls, $M C$, grafite e, mais recente, a oralidade) e por incorporar um discurso político ativo, de denúncia à violência policial e ao racismo.

As ações desenvolvidas pelo poder público e por organizações particulares tiveram impacto na cidade. Mapearam talentos, recursos, coletivos e parcerias que impulsionaram projetos, com o envolvimento desses agentes sociais e políticos nas atividades. A ecologia digital permitiu a superação da barreira da produção. Com os recursos tecnológicos foi possível dominar o ciclo de produção da informação, o desafio da edição e a distribuição para a fruição.

O mapeamento sinaliza o potencial inovador para a formação dos projetos de extensão. Estes articulam ensino (relação pedagógica dinâmica), pesquisa (o mapeamento é um exercício de estudo, reflexão e desenvolvimento de metódicas de captação e armazenamento de dados e informações), gestão (compreensão dos mecanismos de gestão de processos, pessoas e recursos) e extensão, que consiste no aprendizado na e com a comunidade, para a formulação de políticas públicas inclusivas para os segmentos em situação de vulnerabilidade social.

Os projetos de extensão, ao aproximarem a universidade da comunidade, evidenciam a existência de novos espaços para o aprendizado. A cidade criativa, em seus processos e complexidade, emerge como um espaço "aprendente", atravessados por contradições econômicas, políticas, sociais e culturais, conflitos (choques de interesses na ocupação do território) e de superação, com a elaboração de políticas públicas de atenção e inclusão. 
Tais projetos dão retorno à cidade do investimento empreendido para a formação de novos profissionais, pesquisadores, docentes envolvidos com a realidade factual da cidade e ações e estratégias capazes de contribuir com o desenvolvimento local.

O mapeamento dos ApliCs e das tecnologias sociais poderá contribuir, a partir dos dados e informações sistematizados, com o aumento da compreensão da realidade objetiva da cidade, para a elaboração de políticas inclusivas dos segmentos sociais vulneráveis, esteio do desenvolvimento da economia criativa subalterna, em suas múltiplas dimensões: econômica, política, social, cultural e cidadã.

\section{Referências bibliográficas}

AZEVEDO, M. R. Inovações em arranjos produtivos locais advindos de interações entre pequenas empresas e instituições de ensino e pesquisa. In: REIS VELLOSO, J. P. O Brasil e a economia criativa. Rio de Janeiro: José Olympio, 2008.

BAUMAN, Z. Ensaios sobre o conceito de cultura. Rio de Janeiro: Zahar, 2012.

BRITISH COUNCIL. Série Economia Criativa e Cultural -2: Guia prático para o mapeamento das indústrias criativas. Londres, 2010.

CAIADO, A. S. C. Economia criativa na cidade de São Paulo. São Paulo: FUNDAP, 2011.

CASSIOLATO, J. E.; SZAPIRO, M. Arranjos e sistemas produtivos e inovativos locais no Brasil. Rio de Janeiro: IE/UFRJ, 2002.

CASSIOLATO, J. E. Globalização e inovação localizada: experiências de sistemas locais no Mercosul. Brasília: IBICT/IEL, 1995.

DOWNING, J. Mídia radical. São Paulo: Senac, 2002.

FREIRE, P. A educação como prática da liberdade. Rio de Janeiro: Paz e Terra, 1967. Pedagogia do oprimido. Rio de Janeiro: Paz e Terra, 1987. . Pedagogia da autonomia. São Paulo: Paz e Terra, 2006.

FURTADO, C. Essencial Celso Furtado. São Paulo: Companhia das Letras, 2013. 
GRAMSCI, A. Os intelectuais e a organização da cultura. Rio de Janeiro, Civilização Brasileira, 1989.

MARX, K. Contribuição à crítica da economia política. São Paulo: Martins Fontes, 1983.

MINISTÉRIO DA CULTURA. Plano Nacional de Cultura - Diretrizes Gerais. Brasília, 2008.

MINISTÉRIO DA CULTURA. Plano da Secretaria da Economia Criativa - Políticas, diretrizes e ações 2011 a 2014. Brasília, 2011.

OLIVEIRA, J. M., ARAUJO, B. C., SILVA, L. V. Panorama da economia criativa no Brasil - 1880: texto para discussão. Brasília: IPEA, 2013.

POCHMANN, M. Progressos técnicos e subdesenvolvimento. In: REIS VELLOSO, J. P.(Ed.). O Brasil e a economia criativa. Rio de Janeiro: José Olympio, 2008.

REIS VELLOSO, J. P. Como tornar o Brasil o melhor dos BRICs: a estratégia de Economia Criativa voltada para a inovação e a Economia do Conhecimento - sob o signo da incerteza. In: REIS VELLOSO, J. P.(ed.). O Brasil e a economia criativa. Rio de Janeiro: José Olympio, 2008 .

SANTOS, M.; SILVEIRA, M. O Brasil: território e sociedade no início do século XXI. Rio de Janeiro: Record, 2001.

SANTOS, M. Por uma outra globalização. Rio de Janeiro: Record, 2001.

TURINO, C. Ponto de Cultura. São Paulo: Anita Garibaldi, 2010.

UNCTAD. Creative economy report 2010. Creative economy: a feasible development option, 2010. Disponível em: http://unctad.org/en/ Docs/ditctab20103_en.pdf. Acesso em: 16 nov. 2015.

UNESCO. UNESCO world report: investing in cultural diversity and intercultural dialogue, 2009. Disponível em: http://unesdoc.unesco. org/images/0018/001847/184755e.pdf. Acesso em: 16 nov. 2015.

VAINER, C. Quando a cidade vai às ruas. In: Cidades rebeldes. São Paulo: Boitempo, 2014.

XAVIER, J. T. P. Desterritorialização dos arranjos produtivos locais de cultura na ecologia criativa da cidade de São Paulo. In: SIMIS, A. Comunicação, cultura e linguagem. São Paulo: Cultura Acadêmica, 2014a.

Redações desterritorializadas e as possibilidades de modelagem de narrativas objetivas, concretas e factuais. In: BRONOSKY, M. E. Jornalismo e convergência. São Paulo: Cultura Acadêmica, 2014b. 
XAVIER, J.T. P.; XAVIER, P. A. M. TV Digital, educação superior à distância e políticas públicas: interatividade, multimidialidade e hipertextualidade - desafio da formação permanente do gestor de projetos culturais para a diversidade. Extraprensa, v. 2, n. 11, 2012.

XAVIER, J. T. P. Marketing de serviços. Curitiba: IESDE, 2009. 


\title{
5 \\ OBSERVATÓRIO DO ESPORTE: EXTENSÃO E CRÍTICA DA MÍDIA ESPORTIVA NA RÁDIO UNESP FM ${ }^{1}$
}

\author{
Marcos Américo \\ José Carlos Marques \\ Carlo José Napolitano
}

Fábio Camargo Fleury de Oliveira

\section{Introdução}

Para Almeida (2012, documento eletrônico), "os exercícios atléticos estão presentes nas obras épicas de Homero, Ilíada e Odisseia, assim como os jogos tinham por objetivo distrair Odisseu² de sua tristeza". Desta forma, a descrição por Homero de uma luta nos Jogos Fúnebres ${ }^{3}$ gregos no Canto XXIII da Ilíada pode ser considerada, por enquanto, o primeiro registro que se conhece de uma narração esportiva. O fato é que de Homero até hoje, do relato em verso à transmissão audiovisual em alta resolução, do erudito ao apelo popular pela audiência, a percepção do fato esportivo tem se transformado, e os chamados megaeventos esportivos são, além de negócios bilionários, vitrines para inovações em termos de transmissão esportiva.

1 Este capítulo é uma revisão e atualização do trabalho "Observatório do Esporte: uma visão crítica da mídia esportiva”, apresentado no XVIII Congresso de Ciências da Comunicação na Região Sudeste realizado em Bauru, SP, de 3 a 5 de julho de 2013.

2 Odisseu também é chamado Ulisses, herói da Odisseia, de Homero.

3 Cf. Machado (2010, p.21): os jogos fúnebres "eram realizados em honra aos que morreram, para que os vivos não perdessem a memória dos que se foram, e, inclusive, não perdessem a memória de si próprios". 
Há muito o esporte deixou de ser apenas atividade física ou, como queria o Barão Pierre de Coubertain (que defendia com afinco a prática esportiva a serviço da formação do caráter da juventude), uma forma de congraçamento entre os povos por meio do "ideal olímpico". Não esqueçamos que Césares e Fühers souberam muito bem usar o potencial esportivo em prol de seus interesses e necessidades. Um exemplo são os Jogos Olímpicos de 1936, em Berlim, que foram, pela primeira vez na história, ao mesmo tempo televisionados e filmados em película no polêmico documentário "Olympia", de Leni Reifenstahl, lançado somente em 1938. O fato é que o Comitê Olímpico Internacional decidiu em 1931, antes da ascensão de Hitler, que Berlim sediaria os Jogos, e o Führer se apropriou do evento para realizar propaganda nazista.

No Brasil, muito antes da "pátria de chuteiras" rodrigueana e da "pátria do Pan" de 2007, a mídia desempenha importante papel na consolidação dos interesses políticos e econômicos do esporte. Com a realização da Copa do Mundo FIFA Brasil 2014 e os Jogos Olímpicos de 2016 na cidade do Rio de Janeiro, nosso país entra definitivamente no circuito esportivo mundial e são criadas novas demandas não apenas no perfil do profissional que atua na comunicação esportiva, mas também na interpretação dos fatos esportivos por parte da audiência, fazendo que o esporte passe enfim a ser compreendido também como uma questão sociológica, cultural, política e econômica.

Para apreender o potencial do esporte em nosso país pode-se tomar como base a pesquisa "Os consumidores de esportes no Brasil”, elaborada com base no Target Group Index, um estudo contínuo de consumidores representativos da população brasileira residente nos principais centros de consumo da nação e aplicado pelo Ibope Mídia, em parceria com a Kantar Research Media. O levantamento mostra que $64 \%$ da população assistem a esportes na TV e 38\% se dedicam a alguma atividade física, ainda que de forma ocasional. Futebol e caminhada se destacam entre os mais praticados, enquanto o automobilismo, ao lado do futebol, aparece entre os mais assistidos. Conforme explica Roberto Lobl, diretor do 
Ibope Mídia: "de forma geral, 72\% da população entre 12 e 64 anos se interessam de alguma forma por esportes, o que dá uma ideia do potencial deste mercado. São cerca de 45 milhões de pessoas”. O principal resultado do relatório aponta a divisão da população em seis grupos distintos, apresentados como superativos, sports fans, esportistas de sofá, saudáveis, sedentários e desinteressados. Essa análise cruza a frequência e variedade da prática esportiva com o consumo de mídia sobre o assunto. O Brasil, dos países latino-americanos, apresenta o menor número de desinteressados - cerca de $29 \%$ da nossa população, contra 36\% dos mexicanos e $42 \%$ dos argentinos.

\section{Objetivos do projeto de extensão "Observatório do Esporte"}

O "Observatório do Esporte" é um projeto de extensão universitária, financiado pela Pró-reitoria de Extensão Universitária (Proex) da Unesp e apoiado pelo Grupo de Estudo em Comunicação Esportiva e Futebol (Gecef), ${ }^{4}$ que busca responder, entre outras perguntas pertinentes, àquelas apontadas por Eduardo Monteiro em seu artigo "Esporte é saúde?": 5

Qual o tom dado pelas mídias nas coberturas esportivas das grandes competições? Como tratam o esporte de alto nível? E as demais instâncias esportivas? De que forma o sucesso das estrelas do esporte, as cifras divulgadas nas suas negociações e o assédio que recebem influenciam as crianças e jovens? Como a mídia se relaciona com o esporte moderno? Quem são e como trabalham os cronistas esportivos? Que relações mantêm os atletas profissionais

4 Grupo de pesquisa cadastrado no Diretório de Grupos de Pesquisa do CNPq. Informações disponíveis em: http://dgp.cnpq.br/buscaoperacional/ detalhegrupo.jsp? grupo=0330609LW6DNZ8. Acesso em: 10 maio 2013.

5 Disponível em: http://www.multirio.rj.gov.br/sec21/chave_artigo.asp?cod_ artigo=1356. Acesso em: 23 abr. 2013. 
com a mídia e vice-versa? Que fatores podem contribuir para o seu afastamento ou aproximação? (Monteiro, 2011).

Para cumprir tal objetivo, o projeto "Observatório do Esporte" é composto por professores, alunos e profissionais das diferentes áreas da Comunicação Esportiva para estudar, produzir e difundir pela Rádio Unesp FM e pelas linguagens das diversas mídias que a web agrega, os fatos e as modalidades esportivas nacionais e internacionais.

Os participantes realizam atividades regulares com a finalidade de debater de modo crítico e técnico os eventos esportivos correntes, os jogos, campeonatos e competições; difundir informações conceituais sobre as modalidades das competições esportivas; divulgar resultados, atuação de jogadores e equipes; informar e discutir sobre grandes momentos do esporte mundial, relembrando fatos históricos com suporte de material sonoro e debate atualizado e preciso, com o objetivo explícito de informar e entreter o ouvinte; dar voz e opinião aos ouvintes nos diferentes espaços de manifestação do site, uma possibilidade concreta de interação propiciada pela internet; oferecer aprendizado profissional e difundir a produção dos professores, estudantes e colaboradores de Jornalismo e Radialismo; pesquisar tecnologias e ferramentas digitais para produção e difusão esportiva pela internet; e estudar e aplicar novas linguagens e formatos para ambientes de web-comunicação. O projeto busca articular extensão e profissionalização em Jornalismo e Radialismo esportivos, para que o ensino-aprendizado dos alunos do curso de Comunicação Social ocorra de modo atualizado e dinâmico. As atividades são desenvolvidas na Rádio Unesp FM, nos laboratórios de rádio e edição audiovisual do Departamento de Comunicação Social da FAAC/Unesp, Bauru.

\section{Infotretenimento}

Em sua produção, o projeto "Observatório do Esporte" se utiliza da estratégia de infotretenimento, conceito entendido como 
atividade desenvolvida nos períodos de lazer. Assim, raramente se relaciona com o tempo destinado a atividades laborais ou produtivas, sendo considerada uma forma de "distração" ou "passatempo", localizado entre os intervalos destinados ao descanso e ao trabalho.

Bucci (2007) aponta algumas considerações sobre o termo que, segundo o Dicionário etimológico da língua portuguesa (Nascentes, 1932), tem origem no vocábulo espanhol entretenimento, com registros iniciais que remontam ao século XVI e que deriva do verbo latino intertenere $($ inter $=$ entre, e tenere $=$ ter $)$, que significa deter, distrair, enganar, sinônimos que denotam o caráter negativo da palavra já em seu surgimento. Trigo (2003) relata que estes significados estavam atrelados ao conceito de pecado e que eram pertinentes, até o século XIX, às atividades permitidas às elites, que entre as camadas estratificadas socialmente eram aquelas que dispunham do tempo considerado ocioso para destinar ao entretenimento. $\mathrm{Na}$ mesma época a palavra estabeleceu relações com o consumo popular e migrou da ideia de comportamento desregrado para uma conceituação que exprimia um sentido de desaprovação, até depreciativo, posto que era associada a elementos opostos à erudição representados pela cultura da elite de então ou a chamada "arte elevada”. Segundo Gabler (2000), os aristocratas consideravam o entretenimento popular simplesmente diversão alienante e com possibilidades corruptivas, que na verdade era, para além da estética, uma discussão sobre poder.

O método de administração científica de Taylor e a linha de produção de Ford influenciam, já no final dos anos 1920, as ideias da incipiente Escola de Frankfurt, ${ }^{6}$ que gestará de forma inconteste na década seguinte o conceito de indústria cultural proposto por Theodor Adorno (1903-1969) e Max Horkheimer (1895-1973), definida como a "vulgarização da arte superior e inferior e sua distribuição através de veículos de comunicação de massa mani-

6 Conforme Lopes (1993), termo que se refere à produção teórica do Instituto de Pesquisas Sociais da Universidade de Frankfurt, à qual se vinculavam Theodor Adorno, Max Horkheimer, Walter Benjamin (década de 1930 e depois 
puladores e aniquiladores da consciência e do pensamento crítico humano", 7 ou seja, a exploração programada e sistemática dos bens simbólicos transformando as atividades de lazer e entretenimento em produtos que incorporam em seu modo de produção as características da industrialização emergente e que trazem embutidos a ideologia dominante.

Com a conversão da cultura em mercadoria e seu uso manipulatório, a percepção de entretenimento alterou-se e passou a ser conduzida pela possibilidade de consumo nesse ambiente mercadológico que então se configurava. Uma das características primordiais da indústria cultural é tornar possível, pela tecnologia, a reprodução de seus bens culturais, fato discutido por Benjamin (2000) em sua obra seminal A obra de arte na época de sua reprodutibilidade técnica, de 1936, na qual o autor afirma que "poderia caracterizar-se a técnica de reprodução dizendo que liberta o objeto reproduzido do domínio da tradição. Ao multiplicar o reproduzido, coloca no lugar de ocorrência única a ocorrência em massa" (Benjamin, 2000, p.79). Assim (o entretenimento),

A partir da segunda metade do século XX, deixou de designar o, digamos assim, estado mental produzido no sujeito que se ocupa da desocupação, deixou de se referir a um atributo de atrações especializadas em distrair a audiência e virou o nome de uma indústria diferenciada. Mais do que uma indústria, um negócio global. Com o advento dos meios de comunicação de massa, a palavra, sempre

da Segunda Guerra) e, mais tarde, Herbert Marcuse. Adorno e Horkheimer desenvolveram pesquisas empíricas com os modernos meios de comunicação de massa, principalmente o rádio, que os levaram a formular os dois conceitos básicos de sua teoria crítica: o de dialética do esclarecimento (crítica à razão, ou ao racionalismo técnico-capitalista) e o de indústria cultural (crítica aos processos dos meios de comunicação de massa que levam à cultura de massa, à homogeneização e à deterioração dos padrões culturais). Disponível em: http:// revistas.univerciencia.org/index.php/comeduc/article/view/3980/3737. Acesso em: 29 jul. 2009.

7 Disponível em: http://www.cra-rj.org.br/site/espaco_opiniao/arquivos/ art045.pdf. Acesso em: 24 fev. 2008. 
que enunciada, traz consigo esse sentido material: o de negócio. Assim como a própria palavra indústria - que antes nomeava apenas uma habilidade humana - mudou inteiramente de sentido com a revolução industrial, a palavra entretenimento foi revolvida por um processo de ressignificação definitivo a partir da indústria do entretenimento (Bucci, 2007).

Por meio do desenvolvimento tecnológico acentuado a partir das duas últimas décadas do século XX e o surgimento da sociedade do conhecimento ocorrem mudanças nos produtos de entretenimento que demandam novas habilidades por parte daqueles que ainda não perceberam que não se trata mais de produto de uma cultura de massa tradicional. O entretenimento deixou de ser apenas "sensorial", numa simples oposição à atividade intelectual, e passou a exigir, além do exercício mental, a ação do corpo e de formas cognitivas antes desnecessárias. Portanto, as mídias digitais revolucionaram a indústria do entretenimento, proporcionando novo paradigma em suas formas de recepção.

Um importante referencial para o projeto "Observatório do Esporte" é o conceito de infotretenimento, que para Gutmann é o

termo usado pela literatura especializada para caracterizar a aproximação entre entretenimento e informação. A expressão aparece não em decorrência do fenômeno, que não é de maneira alguma considerado novo, mas justamente devido a uma ampliação contemporânea do debate acadêmico sobre a aproximação entre jornalismo e entretenimento que não contempla um julgamento de valor a priori (Gutmann, 2008, p.2).

Já para Vieira e Américo (2012), existem poucos estudos brasileiros que buscam conceituar o termo e optam por utilizar a grafia "infotretenimento",

um neologismo criado por meio da aglutinação de duas palavras da língua portuguesa e dessa forma, torna-se um termo mais pró- 
ximo da linguagem brasileira. É caracterizado por narrativas de acontecimentos de forma leve, pelo bate-papo e pela ênfase na vida privada. Como bem verifica Dejavite (2006, p.69), "a notícia deve, na sociedade da informação, aparentar as mesmas características da cultura light: ou seja, ser efêmera, circular rapidamente, fornecer dados novos e, ao mesmo tempo, divertir as pessoas". (Vieira \& Américo, 2012, p.16)

\section{Métodos}

O presente projeto se utiliza de uma metodologia de avaliação que incorpora a avaliação qualitativa (Patton, 2003), a avaliação focada na utilização (Patton, 1997, 2002) e a avaliação por uso do processo. A primeira tem o propósito de guiar o pesquisador na escolha de quais métodos qualitativos são apropriados para a investigação avaliativa. Para Patton (1990), o grande desafio da sociedade da informação não é a capacidade de produzir, armazenar ou transmitir informações, mas reconhecer o que é importante saber e, de fato, como utilizar essa informação. A partir dessa ideia é desenvolvida a segunda abordagem utilizada na pesquisa, a avaliação focada na utilização, definida como aquela que "busca envolver os usuários potenciais no processo avaliativo, por meio da participação em todas as etapas da avaliação, inclusive na tomada de decisões sobre a mesma" (Patton, 1998). Na do estudo de caso é preciso levar em conta que as partes envolvidas no processo (stakeholders) devem ser encorajadas a discutir os problemas que foram importantes para elas, atraindo-as assim para um processo de aprendizagem decorrente da lida investigativa. Estas ideias levam, enfim, à terceira abordagem, a avaliação por uso do processo, que pode ser definida como o aprendizado que ocorre durante a avaliação, ou seja, as mudanças individuais ocorridas na forma de pensar e se comportar e que são resultados decorrentes da aprendizagem durante o processo de avaliação. 
A metodologia adotada apresenta ainda elementos da pesquisa-ação, que, de acordo com Thiollent (1985, p.14), é aquela concebida e realizada em estreita associação com uma ação ou com a resolução de um problema coletivo. Os pesquisadores e participantes representativos da situação ou do problema estão envolvidos de modo cooperativo ou participativo. Desroche (1990, p.98) destaca que um dos aspectos da pesquisa-ação é a pesquisa pela ação, isto é, assumida por seus próprios atores, tanto em suas concepções como em sua execução e acompanhamento, que tem por meta a implicação. Também deve passar por avaliação e, conforme Haguete (2003), esta deve ser feita em função de que tipo de processo ela pretende ser, a saber: de geração de conhecimento, educativo ou de mudança. No caso deste projeto, a avaliação acumula as três pretensões.

Para Patton (2002, p.XXII), a utilização de abordagem multimetodológica é fruto do clássico debate entre os métodos qualitativo e quantitativo e tem sido resolvida com o reconhecimento de que uma variedade de abordagens metodológicas são necessárias e críveis. Os métodos mistos podem ser especialmente valiosos e o grande desafio é promover o casamento entre o binômio questão-método ao invés de aderir a alguma ortodoxia metodológica.

\section{Resultados e discussão}

Durante os quatro anos de existência, o "Observatório do Esporte” produziu 165 programas (até 22 de novembro de 2014), que foram veiculados pela Rádio Unesp $\mathrm{FM}^{8}$ e disponíveis no blog do projeto. ${ }^{9}$ Entre os assuntos abordados em suas reportagens e matérias produzidas pelos alunos e voluntários estão temas rele-

8 Disponível em: http://radio.unesp.br/observatoriodoesporte. Acesso em: 24 abr. 2013.

9 Disponível em: http://observatoriodoesporteunesp.blogspot.com. Acesso em: 24 abr. 2013. 
vantes como: "A não obrigatoriedade do diploma e suas influências para a prática do jornalismo, principalmente na editoria de esportes" (programa 121, 11 de maio de 2013); "Psicologia do Esporte e como essa ciência pode influenciar o desempenho dos atletas de alto rendimento" (programa 115, 30 de março de 2013); "Malha e a realização do Campeonato Brasileiro em Bauru” (programa 113, 16 de março de 2013); "O direito a privacidade dos atletas e o papel do jornalismo esportivo: fiscalizar ou informar?" (programa 112, 9 de março de 2013); "Entrevista ao vivo com o ex-locutor Osmar Santos" (programa 106, 24 de novembro de 2012); "Entrevista com Sálvio Spínola, árbitro FIFA, sobre a profissão de árbitro de futebol" (programa 63, 5 de novembro de 2011); "Técnicos de futebol: qual deve ser sua relação com as torcidas organizadas?" (programa 23, 15 de outubro de 2010); e "Os ditadores do esporte: os cartolas eternos" (programa 1, 14 de maio de 2010).

Com o intuito de aproveitar o potencial da internet na divulgação dos programas gravados, foi criado um canal no YouTube, ${ }^{10}$ no qual, além das edições completas do programa, podem ser acessados conteúdos complementares, como edições ampliadas das reportagens especiais veiculadas na Rádio Unesp FM, produzidas pelos alunos bolsistas e voluntários do projeto. Um exemplo é a matéria "Independência da Catalunha e o FC Barcelona", ${ }^{11}$ postada em 22 de novembro de 2014, com 37 minutos de duração.

Dos alunos que participaram como bolsistas (de iniciação científica e de extensão) do projeto desde 2010, sete foram contratados como profissionais com atuação direta na área esportiva em empresas de Comunicação (TV TEM Itapetininga, Assessoria de Imprensa do Bauru Basket Team, Rádio 94 FM e Rádio Bandeirantes AM, Portal Participi). O projeto conta ainda com a participação de sete alunos do programa de pós-graduação (mestrado) em Comunicação

10 Disponível em: https://www.youtube.com/user/obsesporteunespfm. Acesso em: 29 jan. 2015.

11 Disponível em: https://www.youtube.com/watch?v=kaN-J2aqYyw. Acesso em: 29 jan. 2015. 
da Unesp, que desenvolvem pesquisas na área da Comunicação Esportiva (orientados pelos professores responsáveis pelo projeto) contemplando integração com os alunos de graduação, possibilitando a estes a oportunidade de conhecer e participar de discussões no âmbito da pesquisa acadêmica.

Como registrado anteriormente, o "Observatório do Esporte" faz parte do Grupo de Estudo em Comunicação Esportiva e Futebol (Gecef), grupo de pesquisa cadastrado no Diretório de Grupos de Pesquisa do CNPq e que realiza reuniões quinzenais; portanto, seus participantes também estão envolvidos com a pesquisa acadêmica no âmbito da Comunicação e Esporte. Desta forma, as publicações de pesquisas e produções decorrentes do Gecef e sua disseminação na comunidade também podem ser consideradas ações extensionistas. Neste sentido, foram publicados, até 2012, três livros que têm como objeto de reflexão as relações entre Comunicação e Esporte, a saber: Esporte em foco, organizado por Sandra Regina Turtelli (2010, Selo Cultura Acadêmica da Editora Unesp); Futebol, Cinema e Cia.: Ensaios, organizado por José Carlos Marques e Sandra Regina Turtelli (2011, Selo Cultura Acadêmica da Editora Unesp) e Futebol, Comunicação e Cultura, organizado por José Carlos Marques e Jefferson Oliveira Goulart (2012, Editora Intercom). Encontra-se no prelo o quarto título, A Copa das Copas? Reflexões sobre o Mundial de Futebol de 2014 no Brasil, com previsão de publicação para 2015 e com organização de José Carlos Marques (2015, Edições Ludens).

Diante do exposto neste texto, o projeto "Observatório do Esporte" acredita estar cumprindo plenamente sua vocação extensionista, o que pode ser comprovado pela completa adequação às áreas temáticas descritas no Guia de Extensão Universitária da Unesp (2007, p.32), que descreve como Área Temática I a "Comunicação”, definida pelas seguintes palavras-chaves: Comunicação Social; Mídia Comunitária; Comunicação Escrita e Eletrônica; Produção e Difusão de Material Educativo; Televisão Universitária; Rádio Universitária; Capacitação e Qualificação de Recursos Humanos e de Gestores de Políticas Públicas de Comunicação Social; 
Cooperação Interinstitucional e Cooperação Internacional na área. Trata-se de termos que, em sua maioria, também definem a missão e as ações desenvolvidas pelo Projeto de Extensão "Observatório do Esporte", cujo slogan é "o esporte além das quatro linhas".

\section{Referências bibliográficas}

ALMEIDA, M. A. B. Jogos Olímpicos Gregos: discussões históricas. EFDeportes.com, v.17, n.169, 2012. Disponível em: http:// www.efdeportes.com/efd169/jogos-olimpicos-gregos-discussoeshistoricas.htm. Acesso em: 15 dez. 2015.

BENJAMIN, W. A obra de arte na época de sua reprodutibilidade técnica. In: LIMA, L. C. (Org.). Teoria da cultura de massa. São Paulo: Paz e Terra, 2000.

BUCCI, E. A TV Pública não faz, não deveria dizer que faz e, pensando bem, deveria declarar abertamente que não faz entretenimento". Anais do I Fórum Nacional de TVs Públicas: Diagnóstico do Campo Público de Televisão. Brasília: Ministério da Cultura, 2007.

COOK, P. S.; GOMERY, D.; LICHTY, L. W. The Future of News. Washington: Woodrow Wilson Center Press, 1992.

DEJAVITE, F. A. A. INFOtenimento. São Paulo: Paulinas, 2006.

DESROCHE, H. Entreprendre d'apprendre. Paris: Editions Ouvrières, 1990.

GABLER, N. Vida, o Filme. São Paulo: Companhia das Letras, 2000.

GUTMANN, J. F. Aspectos audiovisuais do infotainment: o CQC como propósito de análise. 2008. Disponível em: http://www.tverealidade. facom.ufba.br/coloquio\%20textos/Ju\%20Gutmann.pdf. Acesso em: 1 nov. 2010.

HAGUETTE, T. M. F. Metodologias qualitativas na sociologia. 10.ed. Petrópolis: Vozes, 2003.

LARA, A. Infotenimento: as inter-relações entre entretenimento e notícia nas grades de programação da rádio Band News FM Curitiba. Razón y palabra, ano 15, n.71, 2010.

LOPES, M. I. V. Estratégias metodológicas da pesquisa de recepção. Revista Brasileira de Comunicação, v.2, n.XVI, 1993.

MACHADO, R. P. T. Entre o mito e a história: gênese e desenvolvimento das manifestações atléticas na grécia antiga. 2010. Tese de Doutorado. 
Universidade de São Paulo. Disponível em: http://www.teses.usp.br/ teses/disponiveis/39/39133/tde-16082010-111339/en.php. Acesso em: 15 nov. 2014.

MONTEIRO E. Esporte é saúde?. Disponível em: http://www.multirio. rj.gov.br/sec21/chave_artigo.asp?cod_artigo $=1356$. Acesso em: 10 set. 2011.

NASCENTES, A. Dicionário etimológico da língua portuguesa. Rio de Janeiro: Francisco Alves, 1932.

PATTON, M. Q. Utilization-Focused Evaluation. California: SAGE, 1997.

. Discovering Process Use. Evaluation, v.4, n.2, 1998.

. Qualitative Research and Evaluation Methods. London: SAGE, 2002.

Qualitative Evaluation Checklist. The Evaluation Center. Michigan: Western Michigan University Press, 2003.

. Utilization-Focused Evaluation (U-FE) Checklist. The Evaluation Center - Western Michigan University, 2002. Disponível em: http://www.wmich.edu/evalctr/checklists/ufe.pdf. Acesso em: 12 dez. 2010.

. The Challenges of Making Evaluation. Ensaio, v.13, n.46, 2005.

Process use as a usefulism. New Directions for Evaluation, v.16, n.116, 2010.

SILVA, M. Educação on-line. São Paulo: Loyola, 2003.

THIOLLENT, M. Metodologia da Pesquisa-Ação. São Paulo: Cortez, 1985.

TRIGO, L. G. G. Entretenimento. São Paulo: Senac, 2003.

UNESP - PRÓ-REITORIA DE EXTENSÃO UNIVERSITÁRIA. Guia da Extensão Universitária da UNESP. Disponível em: http:// www.unesp.br/proex. Acesso em: 28 jan. 2015.

VIEIRA, E. C. F.; AMÉRICO, M. Um estudo exploratório sobre o infotretenimento como estratégia na produção de conteúdos regionais para telejornalismo digital. Revista Alterjor, v.1, n.3, 2012. 


\section{6 \\ A LÓGICA DO PIXEL E SPLIT-SCREEN \\ APLICADA NA REALIZAÇÃO DA VINHETA do "PAu a Pixel: CRÍtICA"}

Letícia Passos Affini

Luis Enrique Cazani Júnior

\section{Introdução}

O projeto "Pau a Pixel: Crítica" integra o núcleo de pesquisa, experimentação e extensão "Pau a Pixel", que tem como objetivo fomentar a práxis audiovisual por meio da aplicação, compreensão e decodificação das linguagens midiáticas, seja das mídias tradicionais, com a produção de programas de televisão veiculados pela TV Câmara (canal 10 - NET Bauru), seja das plataformas digitais de comunicação, com a produção de micrometragens postados no ciberespaço e acessados por diferentes interfaces como tablets, smartphones, PCs e netbooks. O projeto é subdivido em "Pau a Pixel: Investiga" e "Pau a Pixel: Crítica", vinculados ao projeto de extensão "Pau a Pixel: Produção de Programas de Televisão Universitária”, realizados por bolsistas e voluntários, graduandos em Comunicação Social/ Radialismo, com apoio da Pró-reitoria de Extensão Universitária (Proex) e do Programa Ciência na Unesp.

Na produção, utilizando os poucos recursos oferecidos pela universidade (numa analogia às construções de pau a pique) e trazendo-a para o contexto tecnológico (com o pixel, menor elemento de exibição e constituição de imagens), surge, então, o nome do projeto, desenvolvido há doze anos na Unesp. 


\section{Objetivos}

Tem-se como objetivo geral do núcleo "Pau a Pixel" o fomento da práxis audiovisual por meio dos seguintes projetos:

- "Pau a Pixel: Crítica": produção de micrometragens com críticas à produção audiovisual, seja cinema, televisão ou ciberespaço, disponibilizados em sites de hospedagem como o YouTube;

- "Pau a Pixel: Produção de Programas de Televisão Universitária": produção de programas de televisão com conteúdos desenvolvidos na universidade para veiculação através de um acordo com a TV Câmara (canal 10 - NET Bauru), permitindo a experimentação da linguagem televisiva;

- “Pau a Pixel: Investiga": proposta de videodicionário constituído de micrometragens com verbetes baseados nas pesquisas dos docentes da instituição, como ferramenta no processo ensino-aprendizagem.

Objetiva-se na construção das vinhetas:

1) Compreender o ciberespaço como meio multimidiático, estabelecido como local de disponibilização de conteúdos audiovisuais, no qual sua linguagem deve estar diretamente relacionada com a concepção de McLuhan (2005) de que "o meio é a mensagem";

2) Inserir o corpo discente recém-ingressado no âmbito da produção audiovisual, pelo desenvolvimento de uma crítica a um produto, iniciando a construção de um repertório que será fundamentado no decorrer de sua formação acadêmica. Inicia-se, assim, o processo de geração do conhecimento e do despertar crítico da profissão;

3) Permitir ao recém-ingressado o conhecimento das regras de utilização de estúdio, seus equipamentos, iluminação, câmeras, foco, zoom, o uso do chroma key, operação de switcher, assim como a prática de tais funções por alunos de outros 
anos do curso de Comunicação Social/ Radialismo vinculados ao projeto;

4) Reconhecer as divergências entre texto escrito e oral, por meio da produção da crítica interdisciplinar realizada pelos calouros nas disciplinas de Língua Portuguesa I e Produção de Programas de Televisão I;

5) Explorar conceitos diretamente ligados à imagem, como a lógica de representação do pixel, a teoria das telas múltiplas (ou split-screen) na produção de uma vinheta;

6) Produzir conteúdos criativos sem ônus, estabelecendo-se no conceito de economia criativa, que fundamenta o projeto.

\section{Justificativa}

A vinheta, considerada inicialmente apenas como elemento de adorno complementar a um determinado produto, tornou-se instrumento de experimentação de técnicas pela sua intensa repetição, que proporciona maiores possibilidades de decodificação pelo receptor. Nasce na videoarte e cresce como vinheta comercial, chegando hoje a todas as produções audiovisuais.

Segundo algumas acepções históricas, o termo provém dos elementos uva, vinho e videira, tidos como símbolos sagrados na Antiguidade. Alguns desses merecem ser destacados, por exemplo, Jesus Cristo (tido como uma videira) e os homens comuns que ele guiava (interpretados como os ramos dessa árvore). Tem-se, ainda, o vinho como a bebida sagrada, também relacionada com essa construção simbólica. Segundo Aznar (1997, p.21):

Como se vê, a videira e seus frutos estão ligados à atividade mitopoética do homem primitivo [...]. Como o homem primitivo tinha uma tendência natural para uma visão simbólico-alegórica do universo, foi no íntimo de sua sensibilidade simbólica que a videira, a uva e o vinho se metamorfosearam, se especificaram, se definiram como elementos representantes de realidades além da 
realidade individual de cada um e puderam entrar como imagens no mundo das artes, das letras e mesmo da doutrina religiosa cristã. Tornaram-se símbolos.

Seguindo o interesse do homem pelas construções simbólicas, surgem as iluminuras que, apresentando textos com suas representações, são manifestações consideradas como as primeiras vinhetas. Os egípcios foram os precursores dessa arte ao ilustrar seus papiros, como os "Livros dos Mortos". A Igreja Católica só adota essa prática no século IV, com o intuito de tornar os textos sagrados entendíveis visualmente. A partir desse momento, entra em cena um processo de evolução, que passa a contar com vários tipos de ilustrações, de diferentes tamanhos, que induzem para o segundo plano a representação espiritual até então preponderante. O conceito de vinheta começa a se formar, ao se observar que as iluminuras atuavam como elementos complementares a uma fórmula já pronta, o texto. Sua popularização se dá com o surgimento da imprensa, na Idade Moderna, ainda mantendo a identidade gráfica iniciada pelas iluminuras.

A vinheta torna-se, então, uma arte que se manifestou na sociedade desde a Antiguidade, partindo do texto até a escultura. Atualmente, pode-se vislumbrar diversas aplicações desse conceito, seja no cinema, no rádio ou na televisão. No primeiro, é entendida como a abertura do filme, na qual são apresentadas as informações iniciais da produção, buscando promovê-las ao público. No rádio, ela aparece nos intervalos dos programas, geralmente formada pela junção de texto oral com instrumental ou música, servindo para a identificação da estação, do programa, do apresentador ou de algum anunciante. Na televisão, tem uma função similar àquela do cinema e do rádio, servindo como abertura de programas e novelas, com estruturas e elementos gráficos exclusivos, desenvolvidos por profissionais importantes dessa forma de arte, como Hans Donner, que criou diversas aberturas memoráveis para a Rede Globo de Televisão. 
A vinheta, inicialmente tida como um produto audiovisual complementar, torna-se interdependente do objeto ao qual está relacionada, construindo uma totalidade significante que vai além da mera soma dessas partes. Assim, a articulação das informações em caráter multidimensional permite relacioná-la com a produção que irá iniciar, como também com o meio de difusão onde será instituída. Deixou de ser um instrumento meramente de adorno para se tornar uma ferramenta de experimentação, promoção, identificação, comunicação e arte.

\section{Métodos e técnicas utilizados}

Na elaboração da vinheta do projeto "Pau a Pixel: Crítica" usou-se como conceitos estéticos: split-screen, a lógica de representação da imagem com o pixel, branded-entertainment e o pensamento complexo, proposto por Morin (2007), com importantes considerações sobre a construção de uma totalidade, assim como o papel das partes que a constituem.

A técnica das múltiplas telas, ou split-screen, consiste na divisão da tela de apresentação em duas ou mais, que passam a veicular, simultaneamente, diferentes conteúdos. Exige do expectador maior grau de atenção para compreender o que é exibido, assim como atrai maior interesse pelo produto, principalmente com a intensa atividade desenvolvida no ciberespaço, meio onde o micrometragem é inserido. Por causa da possibilidade de repetição, um maior número de informações congregadas auxilia o contínuo interesse por parte do expectador, que buscará vislumbrar algo de novo em nova exibição. A técnica se popularizou na década de 1960, com os filmes $O$ homem que detestava as mulheres, de Richard Fleischer, e GrandPrix, de John Frankenheimer. O split-screen costuma ser muito utilizado em cenas de conversas ao telefone (mostrando os dois personagens em questão) e em cenas em que o ator aparece duas ou mais vezes sob ângulos diferentes. Há, também, filmes mais atuais que utilizaram essa técnica, como As virgens suicidas, de 
Sofia Coppola, e a recente comédia romântica 500 dias com ela, de Marc Webb.

Por muito tempo, a execução da técnica se dava pelo uso de uma impressora óptica, responsável por copiar as cenas filmadas separadamente e juntá-las em um mesmo negativo. Nesse projeto, utilizou-se o software de edição não-linear Adobe Premiere CS5 para a divisão da tela e a inclusão de nove vídeos que remetem à gravação da pré-produção do projeto "Pau a Pixel: Crítica", preparativos da gravação da crítica audiovisual que compõe o micrometragem, além dos slogans das agências de fomento, do projeto e da instituição.

A integração das agências de fomento de forma criativa na vinheta foi possibilitada pela ferramenta publicitária branded-entertainment: também denominada de entretenimento de marca, conjuga-se a marca ao jogo das múltiplas telas do processo de pré- produção. Tanto as diferentes etapas gravadas e projetadas em telas múltiplas quanto a inclusão dos slogans constituem e fazem o projeto em questão, remetendo à formação do logo do projeto ao final de exibição. As partes estão no todo (que é o projeto assim representado pelo logo ao final) e o todo está nas partes (na articulação mutildimensional do projeto, seja por meio da produção, seja em seu financiamento). Segue, portanto, o princípio hologramático proposto por Morin (2007) - o todo é considerado maior do que a soma das partes, no qual se apresenta a conjugação da multiplicidade de relações em uma estrutura uniforme.

Por fim, explora-se o conceito diretamente ligado à imagem, com a lógica de representação do pixel. O termo, que provém da junção das iniciais das palavras inglesas picture e element, em livre tradução, corresponde ao menor elemento que compõe um dispositivo de exibição e de formação de imagens, tanto para vídeos quanto para fotos. Define o grau de resolução das mídias eletrônicas segundo a seguinte lógica: quanto menor a área de representação do pixel em uma imagem, maior será a nitidez dessa parte. Em um monitor colorido, cada pixel é composto por um conjunto de três pontos: verdes, vermelhos e azuis, sendo capazes de exibir 256 tonalidades diferentes no sinal analógico, atrelado a esses três pontos. Já a 
televisão analógica tem a capacidade de exibição proposta por 525 linhas horizontais, e a digital possui 1.080 linhas, atualmente. $\mathrm{Na}$ vinheta, a aplicação do split-screen em cada tela passa a representar uma parte da imagem do logo do projeto, como propõe a própria lógica do pixel, em um processo metalinguístico. A vinheta produzida foi criada sem ônus, estabelecendo-se no conceito de economia criativa, utilizando o equipamento da própria universidade.

\section{Descrição do produto ou processo}

A vinheta, com dez segundos de duração, é composta por nove vídeos executados simultaneamente e distribuídos segundo os conceitos de split-screen, a representação da imagem com o pixel e o branded-entertainment. Integra cerca de trinta micrometragens disponibilizados no ciberespaço em sites de hospedagem como YouTube, e possui, como sonorização, "Pump up the Jam", do Techonotronic. O projeto "Pau a Pixel: Crítica” conta com cem micrometragens produzidas, integrando o núcleo de pesquisa, experimentação e extensão "Pau a Pixel", com cerca de oito temporadas de programas de televisão veiculadas pela TV Câmara nesses oito anos.

\section{Considerações finais}

A vinheta de abertura dos micrometragens torna-se uma referência no meio ciberespaço, que institui a simultaneidade, a curta duração de seus produtos e a agilidade na promoção das ações. Possibilitou a aplicação e a experimentação de conceitos diretamente ligados à imagem, como o exercício da práxis audiovisual, bem como a introdução de maior número de informações na tela, de forma criativa e a evitar a perda do interesse com suas repetições. $\mathrm{O}$ sucesso de sua realização possibilitou a padronização dos conteúdos produzidos pelo núcleo, com sua inclusão nos programas de televisão desenvolvidos pelo projeto. 


\section{Referências bibliográficas}

AZNAR, S. C. Vinheta: do pergaminho ao vídeo. São Paulo: Arte \& Ciência, 1997.

MCLUHAN, M. Os meios de comunicação como extensões do homem. São Paulo: Cultrix, 2005.

MORIN, E. Introdução ao pensamento complexo. Porto Alegre: Sulina, 2007. 


\section{7 \\ JORNALISMO COLABORATIVO: \\ A COMUNIDADE NA PRÁTICA JORNALÍSTICA \\ DE TELEVISÃO}

Francisco Machado Filho

Mayra Fernanda Ferreira

\section{Introdução}

No cenário de convergência midiática, torna-se necessário rediscutir a participação dos receptores frente aos conteúdos de mídia, uma vez que, por meio das ferramentas interativas advindas com a internet, os receptores tornam-se usuários interativos ou, como pontua Primo (2007), interagentes. Do papel de meros receptores de uma mensagem, tornam-se receptores ativos, já que podem interagir, aceitando, comentando e criticando uma mensagem, e potenciais coprodutores, dado que podem produzir e veicular mensagens em diferentes plataformas.

Considerando que a televisão é ainda o meio de maior alcance entre o público e que os telejornais também são um dos produtos de maior audiência das emissoras de TV, vale considerar como os telejornais podem, e devem, contar com a presença e a participação de seus espectadores. Ao observar a rotina de um telejornal, com suas técnicas, padronizações e hierarquização da redação, em um primeiro momento, inserir o público nesse modelo produtivo é tarefa árdua. No entanto cabe ressaltar que é a partir da audiência presumida e almejada pelos telejornais, como pontua Pereira Junior (2006), que são definidas as pautas e os formatos em que os conteúdos serão transmitidos e chegarão aos telespectadores. 
Nesse sentido, entendemos que incluir comunidades na prática telejornalística, da pauta à reportagem, da edição à veiculação, garante uma proximidade do produto com seu público. Não uma proximidade necessariamente física, mas de interesses informacionais, troca de experiências e construção coletiva de conhecimento em um produto jornalístico, visto que o jornalismo deve ser entendido como prática de compromisso social, cidadão e (in)formativo, na qual há necessidade de identificações e presentificações para que públicos e produtores de informação estejam em sintonia.

Tal sintonia, ou melhor, sinergia, é ainda mais acentuada nesse cenário convergente e colaborativo das mídias na contemporaneidade. Embora a televisão seja um meio interativo quando se pensa na atividade do telespectador ao ligar e desligar e sintonizar os canais, a interação entre os produtores e receptadores ainda é um campo em exploração, ou seja, são pontuais os exemplos e experiências nas quais os telespectadores foram chamados a interagir. Do programa Você decide ${ }^{1}$ da Rede Globo, ao quadro "Parceiros do RJ", ${ }^{2}$ há uma distância temporal, mas principalmente de atuação e reconhecimento do público como potencial produtor de conteúdo.

Visando reconhecer esse novo espectador, este estudo expõe, portanto, a proposta de um jornalismo colaborativo a ser realizado em uma comunidade de Bauru, de modo a capacitá-la para que seja participante e coautora de conteúdos jornalísticos mais condizentes

1 O programa Você decide, enquanto dramaturgia, foi veiculado pela Rede Globo de Televisão entre os anos de 1992 e 2000. O enredo possibilitava ao telespectador escolher, por meio de voto pelo telefone, qual o melhor desfecho entre possibilidades apresentadas durante o programa.

2 O quadro "Parceiros do RJ", assim como o "Parceiros de SP", é uma proposta da Rede Globo, desde 2011, de inserir comunidades em seus telejornais. Como enuncia o site da emissora: o quadro, apresentado no RJTV, mostra a realidade de diferentes regiões da região metropolitana do Rio sob o ponto de vista do próprio morador. É ele quem apresenta o lugar em que vive, com um olhar que só ele tem, produzindo conteúdo para o telejornal" (TV Globo, 2013). Para participar do quadro, jovens se inscrevem no Banco de Talentos da Globo, participam de uma seleção e, se selecionados, fazem uma oficina e são contratados pela emissora para integrarem a produção de reportagens sobre as comunidades que representam. 
com seus próprios interesses. Tais conteúdos, ao serem veiculados pela televisão, são uma forma de promover interações, trocas de experiências e autoexpressividade de grupos, como defende o modelo de Comunicação Participativa de Kaplún (1983a). O ambiente de uma televisão universitária, a nosso ver, é o espaço para essas experimentações na medida em que a prática de um jornalismo público enquanto linha editorial articula-se com o método participativo e democrático do jornalismo colaborativo. É por isso que o projeto em questão foi realizado, no período de março de 2013 a março de 2015, em parceria com a TV Unesp, uma emissora pública, cultural e educativa.

\section{Comunicação participativa e jornalismo público}

O direito à participação implica aceitar o desafio de criticar e transformar os obstáculos culturais, políticos, econômicos ou sociais, para que a participação tenha o sentido moral de direito ao desenvolvimento humano. [...] Pressupõe o desenvolvimento da capacidade de dialogar, comunicar e incidir tanto no âmbito político como em todas as esferas da vida (Klainer; Lòpez; Piera, 2004, p.161).

Concordando com a citação, a participação deve garantir aos cidadãos uma autonomia para atuar na sociedade e construir espaços democráticos que estejam afins aos seus interesses. Nesse processo de construção e transformação social, é necessário que os cidadãos sejam os porta-vozes desses interesses e, para isso, canais de comunicação são imprescindíveis, assegurando o direito à livre expressão.

Em seus estudos, Kaplún propôs o modelo de comunicação participativa, visando valorizar a autoexpressividade dos indivíduos. Nesse modelo, os grupos e as comunidades assumem suas vozes para emitir mensagens e interferir no processo comunicativo. A comunicação, então, passa a ser horizontal, na qual há diferentes 
interlocutores, visto que não há mais distinção entre emissores e receptores, o que favorece uma prática democrática. Kaplún (1983a), então, defende uma concepção de comunicação como participação, interação e diálogo.

A través del medio, los grupos pueden dialogar, intercomunicarse; y entablar asimismo una relación de diálogo - una comunicación de doble via - con los educadores-comunicadores. El medio interconecta a los grupos, los une a distancia y permite el intercambio y confrontación de mensajes y la construcción entre todos de un nuevo mensaje común (Kaplún, 1983b, p.52).

A partir dessa troca e construção de mensagens, os grupos se autovalorizam, uma vez que reconhecem a importância de sua voz, por causa da autoexpressão, e sua contribuição para a sociedade à qual pertencem. Esse potencial para o desenvolvimento social é exaltado por Kaplún (1984), já que ele considera que sem participação não há desenvolvimento, pois, por meio dela, os indivíduos assumem seu papel de protagonistas e criam as soluções para os próprios problemas. A comunicação participativa, então, é uma potencialidade para que haja espaços que valorizem o que os indivíduos têm a dizer de modo a provocar e concretizar ações em prol do desenvolvimento social de uma sociedade que se propõe democrática.

Como uma prática comunicativa, o jornalismo público (JP) se insere nessa defesa e na promoção da democracia, cidadania e liberdade, como enuncia seus preceitos (TV Cultura, 2004), visando à formação crítica dos telespectadores. Ao reconhecer enquanto público os cidadãos, o JP tem como temas o cotidiano e a agenda social destes, buscando sempre um novo foco e aprofundando as discussões.

O JP [jornalismo público] age movido pela certeza de que a informação é um bem preciso (um meio de "educação permanente"), de posse do qual o receptor compreende melhor a realidade que o circunda, forma juízos, reconsidera posições e se abre para o 
resto da humanidade [...]. O objetivo é atingir o telespectador-cidadão, não o indivíduo fragmentado, entendido na sua dimensão exclusivamente pessoal (TV Cultura, 2004, p.38).

No exercício desse jornalismo público, estabelece-se nova relação entre quem produz e recebe as informações, na qual a palavra-chave é o diálogo. Os jornalistas atuam como mediadores da informação para enriquecer e ampliar o que é apresentado pelos outros veículos de informação, sempre de modo compatível e consistente com o projeto da emissora e com o interesse da sociedade. $\mathrm{Na}$ construção de tal novo modelo (cujo exercício é mais viável dentro de uma emissora pública, como enunciaremos mais adiante), formatos precisam ser revistos, já que nos encontramos em um espaço de experimentação, no qual o "jornalismo que aspira à relevância tem de levar em conta a ideia de transgressão" (TV Cultura, 2004, p.53).

Essa "transgressão" está na direção da convergência e da interação necessárias para que o público se insira na rotina midiática de um telejornal e possa participar mais efetivamente de todas as etapas, da produção de pautas até a avaliação do material veiculado o JP, nesse sentido, atua mais como mediação do que produtor unilateral. Tal liberdade de produção possibilita que os jornalistas sejam coprotagonistas em meio às interações sociais.

O ideal de interlocução sugerido pelo JP contempla mudanças no comportamento do receptor e do emissor. O primeiro não deve se resignar à condição de plateia passiva; o outro, tirano na hora de programar o temário, se abre para o diálogo. Da renúncia de ambos emergem novas oportunidades de interação, a serem negociadas no âmbito do espaço público [...]. Ao compartilhar responsabilidades, os parceiros não podem afrouxar os termos da aliança (TV Cultura, 2004, p.48).

Nessa interação entre produtor e telespectador prevalece, portanto, o diálogo, para que os espectadores possam conhecer os 
processos de produção e veiculação, como propõe o modelo colaborativo na comunicação e no jornalismo.

\section{Jornalismo colaborativo e interações possíveis}

Anderson (2006), ao falar de internet, pontua que o fato de qualquer um ser capaz de produzir conteúdos só é significativo se alguém puder desfrutá-los. É por meio do acesso a esses conteúdos que também falamos em interação. A partir do direito à informação, inerente aos cidadãos, estes podem interagir com as mensagens em diferentes meios, ao mesmo tempo em que se aproximam dos produtores, sejam eles "profissionais" de mídia ou não.

Como, na contemporaneidade, o acesso às ferramentas (câmeras portáteis, celulares e internet) que possibilitam a produção de conteúdos diferenciados atinge diferentes segmentos da população, há uma desterritorialização da informação ao passo que todo cidadão torna-se potencialmente um produtor, desde que haja interesse de sua parte, em um primeiro momento, e que a divulgação de sua produção seja reconhecida pelos demais. Afinal, produtores querem que suas mensagens sejam lidas e/ou vistas e/ou ouvidas e/ou comentadas e/ou compartilhadas.

Dentro das possibilidades de produção, o jornalismo também ganha a interferência, nem sempre negativa, dos novos produtores, ou melhor, coprodutores de informação. Seja pelo envio de fotos ou imagens de um fato que vão agregar à notícia, esses coprodutores buscam se identificar com conteúdos a partir da presença de uma realidade mais próxima deles nos jornais, mesmo que sua identidade não seja revelada. Segundo o diretor do Knight Center for Digital Media Entrepreneurship, da Universidade do Arizona, Dan Gilmor, o mais importante hoje é pensar em como se faz esse jornalismo.

"Sair da zona de conforto" é um dos princípios de Gilmor sobre o livre pensar. Como conciliar a preservação da voz anônima na 
participação e ao mesmo tempo manter a credibilidade? Gilmor indica que os jornalistas acompanhem e se atualizem sobre sistemas e recursos para a construção de conteúdos (Saad apud Prado, 2011, p.193).

É evidente que as observações citadas se referem à participação dos usuários na web; no entanto reavaliar o papel dos jornalistas e potencializar os espectadores cabe a diferentes meios, como a televisão. Considerando que esse meio de comunicação ainda detém uma audiência singular em mais de 90\% dos lares brasileiros, além de ser um meio no qual as imagens ganham status de representação da realidade e as pessoas ali retratadas são "espelhos" para os e dos telespectadores e das situações que vivenciam, a participação mais efetiva do público por meio da colaboração direta na definição, produção e veiculação de conteúdos seria uma garantia de maior fidelização e correspondência aos interesses e características dos espectadores.

Inserir o público televisivo na rotina de um telejornal, por exemplo, exige um planejamento por parte da redação no sentido de garantir espaços e formatos para a participação dos cidadãos, ao mesmo tempo em que estes necessitam ser capacitados para utilizar os instrumentos de mídia, caso seja necessário, ou ser informados a respeito das possibilidades de colaboração. Ao nos referirmos à potencialidade colaborativa, estamos indo além da sugestão de pautas por telefone ou e-mail: defendemos que os espectadores podem se tornar protagonistas das narrativas e/ou contadores das notícias como parte integrante delas. É o olhar do espectador atuante como "jornalista" que pode dar um viés mais comunitário e democrático à notícia.

Aproximar a rotina televisiva do telespectador já cativo é abrir caminho para a prática colaborativa. Assim, pensar em uma televisão interativa é um desafio.

Televisão interativa pode ser definida como qualquer coisa que torne possível ao telespectador ou telespectadores se engajarem em 
um diálogo com as pessoas que fazem um canal de televisão, programa ou serviço. Mais especificamente, pode ser definida como um diálogo que leva os telespectadores além da experiência passiva de assistir e os permite fazer escolhas ou praticar ações (Gawlinski, 2003 apud Teixeira, 2009, p.20-21).

Entre as ações e as escolhas, está a prática de um jornalismo colaborativo que defenda os princípios éticos de um jornalismo de interesse público.

\section{Projeto: Comunidade na TV Unesp}

Ao entender a importância do exercício de um jornalismo público que se aproxima da cidadania e, consequentemente, dos interesses de um público que busca e tem um potencial de interagente, tanto em relação aos conteúdos quanto no diálogo com os produtores, uma emissora pública, cultural e educativa torna-se o espaço ideal para experimentações.

Televisão pública é aqui considerada como a que privilegia o caráter público deste meio "para superar a sua visão comercial e ganhar sua densidade como cidadã; a que nos relata como nos tornamos coletivo social. Esse interesse se situa na relevância social, cultural e política que se atribui em nossa sociedade ao caráter 'público' do serviço de televisão” (Rincón, 2002, p.28) [...]. Em suma o sentido de caráter público aponta para a cidadania, participação democrática, visibilidade e protagonismo de amplos setores sociais no processo midiático (Peruzzo, 2007, p.144).

A fim de valorizar tal protagonismo, a TV pública pode abrir portas para a colaboração de seus espectadores. Aliado a esse objetivo, uma emissora pública e universitária é um campo fértil para incluir esses espectadores como agentes sociais e midiáticos que atuem na produção de conteúdos audiovisuais que representem 
uma comunidade e deem voz aos cidadãos. Além disso, o fato de estar vinculada a uma universidade fomenta o espaço de extensão, uma vez que visa ampliar o acesso ao conhecimento e promover transformação em uma dada realidade a partir dos estudos feitos dentro da academia. Como já afirmava Kaplún (1999, p.73), “a construção do conhecimento e sua comunicação não são, como costumamos imaginar, duas etapas sucessivas através das quais primeiro o sujeito se apropria dele e depois o enuncia. São, isso sim, o resultado de uma interação".

Essa interação, ao estar na comunidade, é uma das tarefas e um dos deveres de uma universidade, principalmente da pública. Nesse sentido, o projeto Telejornalismo na TV digital aberta adotou como espaço extensionista a Televisão Universitária Unesp, ${ }^{3}$ que integra o Centro de Rádio e Televisão Cultural e Educativa da Universidade Estadual Paulista. A TV Unesp estreou em 4 de novembro de 2011 com uma programação voltada à comunidade bauruense e unespiana a partir de programas culturais e educativos. O jornalismo da emissora se estruturou, em um primeiro momento, com um programa de entrevista, Fórum, ${ }^{4}$ que visava debater temas de interesse da comunidade, como trânsito, planejamento urbano, alcoolismo, eleições, entre outros.

Em 1을 agosto de 2012, estreou o telejornal Unesp Notícias, ${ }^{5}$ com trinta minutos de duração, cujo foco concentra-se em um jornalismo ao mesmo tempo factual e de aprofundamento, de modo a trazer ao telespectador temas que fazem parte do dia a dia e que podem incitar discussões e reflexões, a partir de entrevistas em estúdio com especialistas, políticos, representantes da sociedade civil e professores.

Para aproximar o público do telejornal, não apenas na abordagem dos temas sociais, está em implantação, desde março de 2013,

3 A Televisão Universitária Unesp (TV Unesp) é sintonizada no canal 45 UHF e 32 da operadora a cabo NET na cidade de Bauru, interior de São Paulo. A programação também está disponível no site www.tv.unesp.br.

4 Disponível em: www.tv.unesp.br/forum.

5 Disponível em: www.tv.unesp.br/unespnoticias. 
o projeto de extensão realizado por professores de Comunicação Social - habilitação em Jornalismo - e alunos bolsistas dos cursos de Jornalismo e Rádio e TV da Unesp, que visa trabalhar com comunidades de Bauru. Enquanto um projeto de extensão em jornalismo colaborativo, este estudo adota como metodologia a imersão na rotina jornalística da Televisão Universitária Unesp, de modo a conhecer as práticas e acompanhar as discussões editoriais para, então, propor um modelo de participação de uma dada comunidade na produção e veiculação de conteúdos no telejornal. A partir da proposta colaborativa, foram realizadas oficinas com a comunidade para que ela conhecesse o telejornalismo não mais como mera telespectadora, mas atuante no processo produtivo.

As atividades do grupo de extensão em Telejornalismo para TV digital aberta foram divididas em três etapas: capacitação, produção e veiculação dos programas jornalísticos. Os alunos ingressantes foram capacitados a planejar e produzir produtos noticiosos audiovisuais para a TV digital aberta utilizando as dependências e os equipamentos da TV Unesp.

Na etapa de capacitação, os participantes se integraram à comunidade não só para a busca de pautas com o interesse e o "olhar" próprios desta, mas também para auxiliar aqueles que demostraram interesse em adquirir conhecimento da nova tecnologia digital de transmissão de conteúdo e suas possibilidades de produção e de uso da interatividade. A comunidade que acolheu o projeto se localiza no bairro Geisel, próximo ao campus da Unesp em Bauru, no estado de São Paulo.

$\mathrm{Na}$ segunda etapa, os alunos produziram um telejornal dentro dos aspectos levantados durante a capacitação, a partir da utilização da ferramenta colaborativa Jcollab (http://www.jcollab. lavid.ufpb.br) desenvolvida por pesquisadores do Laboratório de Aplicações de Vídeo Digital (LAVID), ${ }^{6}$ da Universidade Federal

6 O Laboratório de Vídeo Digital (LAVID), da Universidade Federal da Paraíba, atua desde 2003 visando desenvolver projetos de pesquisa em hardware e software voltados às áreas de vídeo digital, redes de computadores, 
da Paraíba, que permite a participação de espectadores na sugestão de temas, produção e veiculação de conteúdos. Na terceira, estava prevista a pós-produção dos programas e sua veiculação na TV Unesp, contudo a realidade do projeto limitou seus propósitos e objetivos.

Durante a etapa da integração e capacitação dos alunos bolsistas na comunidade escolhida, o que foi constatado é que, diferentemente do senso comum de que a internet e as redes sociais possuem forte adoção e uso pelos indivíduos, as pessoas possuem perfis e utilizam as redes sociais, mas de forma isolada e individualizada. Encontramos extrema dificuldade em sistematizar o uso das redes sociais em prol da comunidade. Não por conta da falta de acesso, nem por falta de interesse, mas pudemos aferir que a própria característica do meio impele as pessoas a agirem individualmente. Ou seja, as pessoas da comunidade que participaram da etapa de capacitação não conseguiram compreender o uso das ferramentas on-line (Jcollab e redes sociais) como um espaço coletivo. Desta forma, o projeto teve limitado seu objetivo principal (que consistia na intensa participação da comunidade na formulação das pautas e envio de material audiovisual para a redação da TV Unesp), forçando os alunos bolsistas a exercerem o papel tradicional dos jornalistas na captação e produção das notícias referentes à comunidade.

\section{Considerações}

Apesar de o objetivo primário não ter sido completamente alcançado, a avaliação final do projeto foi bastante positiva, pois nos permitiu constatar que a premissa do uso das redes sociais e internet ser comum a uma parcela significativa da população é verdadeira no que se refere à abrangência do meio internet, mas falsa no que diz respeito ao modo como os representantes da comunidade e

TV digital e interativa e middleware. Atualmente o LAVID é uma referência nacional e internacional em desenvolvimento de tecnologia para TV digital. 
integrantes do projeto a utilizam de forma coletiva e voltada para a própria comunidade. Verificou-se que é necessário um projeto anterior que contemple a participação coletiva dos integrantes da comunidade voltada para seus anseios e necessidades comuns por meio das ferramentas on-line. Desta forma, o projeto encerrou suas atividades em março de 2015 com dados e experiências para a formatação de um novo projeto que poderá ser aplicado nesta mesma comunidade. Contudo não se perdeu a intenção de promover um telejornalismo público e cidadão não apenas para as comunidades, mas com as comunidades inseridas na realização do conteúdo. A tecnologia atual já permite tal participação e envolvimento, mas é preciso concretizar o sentimento participativo e comunitário também no ambiente digital.

Não se pode perder de vista a estratégia de facilitar a participação popular direta, com partilha do poder de decisão, como forma de ampliar o exercício da cidadania comunicacional. Ninguém nasce sabendo fazer televisão. É preciso criar condições para a produção audiovisual por parte de qualquer cidadão e das lideranças das organizações sociais (Peruzzo, 2007, p.158).

De acordo com a autora citada, é preciso garantir os instrumentos para que o público possa fazer televisão e, assim, estabelecer mecanismos para uma participação efetiva em direção à cidadania. Nesse sentido, a proposta apresentada neste capítulo direcionou-se, enquanto uma extensão universitária, à promoção de um jornalismo colaborativo a partir do olhar e da atuação de uma comunidade.

Ao pensar na prática colaborativa, será possível esse exercício, visto que a preocupação com a audiência, por exemplo, terá um novo foco: a audiência também é a produtora do conteúdo, sendo livre para expressar o que deseja e pensa, principalmente ao contar com a oportunidade de avaliar e alterar o modo de produção conforme suas habilidades, necessidades e interesses no telejornalismo.

Tendo em vista que a interação é uma possibilidade para que os conteúdos dialoguem com o público, ao mesmo tempo em que os 
interagentes estão em interação entre si, a prática telejornalística pode se beneficiar desse cenário, ao promover práticas colaborativas. Este estudo é um ponto de partida possível, uma vez que espera abrir espaço para uma comunidade participar do exercício público de telejornalismo de uma televisão pública e universitária.

\section{Referências bibliográficas}

ANDERSON, C. A cauda longa. Rio de Janeiro: Campus, 2006.

KAPLÚN, M. Processos educativos e canais de comunicação. Revista Comunicação E Educação, ano V, n.14, jan-abr. 1999. Comunicación entre grupos. Otawa: CIID, 1984. . Hacia una comunicación participativa. Quito: Aler, 1983a. Hacia nuevas estratégias de comunicación en la educación de adultos. Santiago: Oficina Regional de la Unesco para America Latina y el Caribe, 1983b.

KLAINER, R.; LÒPEZ, D.; PIERA, V. Diálogos com crianças e jovens. Porto Alegre: Artmed, 2004.

PEREIRA JÚNIOR, A. E. V. Telejornalismo: das rotinas produtivas à audiência presumida. In: , PORCELlO, F. A. C. (Orgs.). Telejornalismo: a nova praça pública. Florianópolis: Insular, 2006.

PERUZZO, C. Televisão comunitária. Rio de Janeiro: Mauad X, 2007.

PRADO, M. Webjornalismo. Rio de Janeiro: LTC, 2011.

PRIMO, A. Interação mediada por computador. Porto Alegre: Sulina, 2007.

TEIXEIRA, L. Televisão digital. Goiânia: UCG, 2009.

TV CULTURA. Jornalismo Público. São Paulo, 2004.

TV GLOBO. Banco de talentos. Disponível em: www.globo.com. Acesso em: 20 ago. 2013. 


\section{8 \\ EMPREENDEDORISMO E FORMAÇÃO PROFISSIONAL NA EXTENSÃO: A CONTRIBUIÇÃO DA AGÊNCIA JÚNIOR DE JORNALISMO DA UNESP NA VISÃO DE SEUS EX-INTEGRANTES}

Francisco Rolfsen Belda

\section{Introdução}

Este capítulo trata da inserção de atividades de empreendedorismo na formação jornalística a partir de uma pesquisa realizada em torno de um projeto de extensão universitária: a Agência Júnior de Jornalismo, em operação desde 2006 junto do Departamento de Comunicação Social da Faculdade de Arquitetura, Artes e Comunicação da Unesp, em Bauru.

O texto descreve e analisa o funcionamento da agência nos moldes de uma empresa júnior, com equipes divididas em setores de superintendência, administração e finanças, comercialização, desenvolvimento de projetos e serviços, marketing e gestão de pessoas. A partir de depoimentos de 22 ex-alunos envolvidos no projeto, discute-se até que ponto a articulação entre teorias e práticas ligadas ao empreendedorismo concorre, nesse caso, para a formação dos estudantes, considerando o perfil curricular do curso, a vocação extensionista da universidade e as relações mantidas, nesse âmbito, com empresas e agentes econômicos externos ligados ao campo do jornalismo.

Discute-se, por fim, de que forma um entendimento abrangente da extensão universitária poderia favorecer e dinamizar a operação de empresas juniores pela inserção sistemática de teorias, conceitos, 
técnicas e práticas laboratoriais relacionadas ao empreendedorismo nos processos de ensino e aprendizagem do jornalismo, considerando tendências e cenários contemporâneos das relações de trabalho que se estabelecem nesse campo profissional.

\section{Empreendedorismo, empresas juniores e formação em jornalismo}

Para contextualizar os dados reunidos neste trabalho, é importante notar como se insere a noção de empreendedorismo no campo universitário da formação de jornalistas, de modo a considerar por quais meios e até que ponto a articulação entre teorias e práticas vinculadas ao tema pode estimular o desenvolvimento de habilidades e competências específicas pelos estudantes de jornalismo.

Ao se debruçarem sobre o tema, Roxo e Grohmann (2014) procuraram compreender os sentidos assumidos pela noção de empreendedorismo em sua relação com o campo profissional do jornalismo, no contexto de um mercado de trabalho e de programas de formação que se transformam diante da flexibilização das condições de exercício da profissão e da emergência de novos processos de produção. No trabalho em questão, concluem que:

essa noção, que parte de uma gramática do mundo empresarial, tem ganhado expressão no jornalismo, como produto de práticas e discursos que se relacionam ao mercado de trabalho contemporâneo e que atuam na constituição de subjetividades. Embora não isentas de tensões e contradições, as narrativas sobre o empreendedorismo se articulam, de alguma maneira, à lógica prescritiva de um comportamento supostamente capaz de potencializar as oportunidades e diversificar as modalidades de ocupação, a partir de uma ética empresarial do trabalho (Roxo; Grohmann, 2014, p.10-11).

Grohmann (2012) identifica um sentido de identidade que se estabelece em torno de práticas profissionais autônomas comumen- 
te associadas, nesse novo contexto profissional, à ideia de empreendedorismo. Para isso, toma por base uma análise sobre o discurso assumido por jornalistas freelancers em relação aos desafios de seu trabalho, cujas "prescrições" parecem cada vez mais ajustadas a um "novo espírito do capitalismo", em que valores liberais associados à aventura, autonomia, liberdade, atualidade, competição, senso de oportunidade, ímpeto empreendedor, entre outros, passam a constituir valores impulsionadores de uma pretensa reinvenção da profissão.

A atenção ao empreendedorismo como parte da formação de jornalistas é expressa também no documento base formulado pela comissão de especialistas nomeada pelo Ministério da Educação para a elaboração das Novas Diretrizes Curriculares para os Cursos de Jornalismo no Brasil, ${ }^{1}$ no qual consta, como indicativo para os projetos pedagógicos desses cursos, a necessidade de se perseguir a transformação e o aprimoramento das práticas jornalísticas por meio de projetos inovadores, de modo a "projetar a função social da profissão em contextos ainda não delineados no presente", bem como, em parte de seus programas de ensino, "dar ênfase ao espírito empreendedor" necessário ao exercício profissional nesses novos contextos.

Frente a esse panorama, é possível identificar nas empresas juniores um espaço de formação privilegiado para se avaliar como temas e ações relacionadas ao empreendedorismo podem contribuir para a formação superior em jornalismo.

No Brasil, empresas juniores começaram a ser fundadas a partir de 1988, por meio das escolas de administração e negócios da Fundação Getúlio Vargas (FGV) e da Fundação Armando Álvares Penteado (FAAP). Vale notar, como aponta Matos (1997), que o movimento chega ao país duas décadas após a fundação, em 1967,

1 Diretrizes Curriculares Nacionais para o Curso de Jornalismo. Relatório da Comissão de Especialistas instituída pelo Ministério da Educação. Portaria n. 203/2009, de 12 de fevereiro de 2009. Disponível em: http://portal.mec. gov.br/dmdocuments/documento_final_cursos_jornalismo.pdf. Acesso em: 11 out. 2014. 
da pioneira Junior-Entreprise, ligada à Ecole Supérieure des Sciences Economiques et Commerciales de Paris (Essec), na França, organização acadêmica com foco profissional que visava proporcionar experiência empresarial aos estudantes, levando-os a prestar serviços de consultoria para empresas atuantes no mercado de trabalho. Nas décadas seguintes, o modelo espalhou-se por escolas de engenharia e administração na Europa e na América, chegando também aos cursos de comunicação.

De acordo com a Confederação Brasileira de Empresas Juniores, a Brasil Júnior, essas operações definem-se como empresas gerenciadas por estudantes universitários que, por meio delas, realizam projetos e prestam serviços relacionados a suas áreas de formação. Sua finalidade deve ser a de "desenvolver profissionalmente as pessoas que compõem o quadro social por meio da vivência empresarial, realizando projetos e serviços [...] preferencialmente para micro e pequenas empresas e terceiro setor" e, assim, também "fomentar o empreendedorismo de seus associados". ${ }^{2}$ Segundo a Federação das Empresas Juniores do Estado do Paraná (Fejepar), tais organizações também se caracterizam por ter como objetivos, entre outros:

Proporcionar ao estudante a aplicação prática de conhecimentos teóricos, relativos à área de formação profissional específica; desenvolver o espírito crítico, analítico e empreendedor do aluno; intensificar o relacionamento empresa-escola; facilitar o ingresso de futuros profissionais no mercado, colocando-os em contato direto com o seu mercado de trabalho; contribuir com a sociedade, através de prestação de serviços, proporcionando ao micro, pequeno e médio empresário, especialmente, um trabalho de qualidade a preços acessíveis. ${ }^{3}$

2 Conceito Nacional de Empresa Júnior (CNEJ), Capítulo II, Artigo 3o Confederação Brasileira de Empresas Juniores. Disponível em: http://www. brasiljunior.org.br/arquivos. Acesso em: 15 jan. 2015.

3 Fonte: FEJEPAR, Federação das Empresas Juniores do Estado do Paraná. Disponível em: http://www.fejepar.org.br/mej. Acesso em: 25 fev. 2014. 
Essa oportunidade especial de formação também se relaciona à ideia de que o novo contexto profissional exige do estudante de jornalismo uma atenção especial ao aspecto empreendedor de sua futura atuação. Esta visão é reforçada em obras como a de Briggs (2012) e também considerada oportuna na visão de professores como Jeremy Kaplan, diretor do Tow-Knight Center for Entrepreneurial Journalism na City University of New York Graduate School of Journalism, ${ }^{4}$ e Urbano Nojosa, da PUC em São Paulo, para quem a "nova estrutura de negócios" vigente no campo profissional do jornalismo "abre novas áreas de atuação, novos negócios", que exigem que o jornalista se torne um profissional "mais empreendedor" (apud Ribeiro, 2013).

Cleyton Carlos Torres, em artigo no site Observatório da Imprensa (2012), atribui a falta de uma formação adequada a essas novas circunstâncias profissionais à lacuna que permearia "todo o sistema educacional brasileiro", no qual estudantes seriam prioritariamente treinados para "receber ordens e desempenhar [...] funções", em vez de serem preparados para poder também, eventualmente, criar suas próprias empresas ou atuar por meio de parcerias e colaborações estabelecidas e geridas por eles próprios com certa dose de autonomia no já saturado e bastante movediço mercado contemporâneo de comunicação.

\section{A Agência Júnior de Jornalismo na Unesp}

A Agência Júnior de Jornalismo da Unesp foi criada em 2006 com a missão de aproximar os estudantes do mercado de trabalho regional. Como projeto de extensão, valoriza o papel do jornalista na condição de agente social e, com seus serviços, busca atender demandas da comunidade local planejando, desenvolvendo e distribuindo conteúdos informativos e outros produtos que atendam

4 Disponível em: http://www.towknight.org/. Acesso em: 15 jan. 2015. 
às necessidades de um público real. Com isso, seus integrantes podem experimentar as condições práticas da profissão e explorar os recursos técnicos e intelectuais empregados na criação de empreendimentos de jornalismo, de modo a complementar a formação acadêmica oferecida pelo curso de Jornalismo da Unesp.

A agência está atualmente estruturada em dois grandes setores: a coordenação executiva e as equipes de produção. O primeiro é composto por cinco núcleos, cada um com, pelo menos, um estudante veterano atuando como supervisor e outro, calouro, como trainee. Esses núcleos cuidam da superintendência, administração e finanças, projetos e serviços (incluindo ações de comunicação, criação, logística e controle de qualidade), comercial e marketing e, por fim, gestão de pessoas. Já o segundo envolve alunos nas funções de repórteres, editores, diagramadores e fotógrafos, que produzem e publicam conteúdo informativo conforme previsto nos contratos de prestação de serviços jornalísticos firmados entre a agência e seus clientes externos e internos, incluindo departamentos e comissões organizadoras de eventos ocasionalmente realizados na própria universidade.

Os alunos integrantes são escolhidos por meio de processos seletivos que avaliam o histórico escolar dos candidatos, sua aptidão para o empreendedorismo na área da comunicação social e seu comprometimento com os valores e as atividades da agência. Os membros da coordenação executiva podem permanecer no projeto por, no máximo, dois anos, sendo um deles como trainee e outro como supervisor.

Apesar de haver uma superintendência, não há hierarquia entre os alunos na tomada de decisões. A direção e coordenação geral dos trabalhos cabe ao professor responsável pelo projeto. As equipes de reportagem podem se revezar em diferentes funções para a produção de conteúdo, conforme os projetos e serviços em curso. O núcleo de gestão de pessoas é responsável pela seleção de candidatos para integrar a equipe de reportagem. O núcleo de projetos e serviços concebe e desenvolve produtos jornalísticos 
a partir de demandas e oportunidades prospectadas pelo núcleo comercial e de marketing. Os contratos firmados pela agência são geridos pelo núcleo administrativo-financeiro. A superintendência é responsável pelo acompanhamento e pela documentação das atividades, mantendo contato com o professor responsável.

Como projeto de extensão, a Jornal Jr. promove uma ligação entre a universidade e a sociedade, visando ao atendimento de necessidades comunicacionais de segmentos da comunidade local e regional e a construção de parceria com empresas e entidades ligadas ao mercado jornalístico regional. Um desses parceiros oriundos do campo profissional é o Jornal da cidade, principal veículo de mídia impressa de Bauru e região, com o qual a agência promove anualmente o Prêmio Novos Talentos do Jornalismo. As melhores reportagens inscritas são publicadas em um suplemento especial do periódico.

Os serviços prestados incluem a criação de boletins informativos, prestação de serviços de assessoria de imprensa para empresas e entidades, criação de sites e portais de conteúdo noticioso, realização de coberturas de eventos de interesse público, entre outras ações condizentes com a missão da agência, que funciona, assim como um laboratório para que o aluno possa aplicar o conhecimento adquirido em sala de aula e experimentar e aplicar novos formatos e modelos de produção e gestão de empreendimentos jornalísticos.

O site da agência apresenta suas informações institucionais e publica relatos sintéticos das coberturas de eventos realizadas, entre outros trabalhos produzidos. Também são promovidas atividades extracurriculares de orientação profissional, como eventos e oficinas que agregam conhecimentos e experiências aos universitários.

São realizadas reuniões mensais para supervisão de contabilidade, avaliação e reorientação dos projetos. Ao final de cada semestre, em reunião de planejamento, os membros da coordenação executiva consideram o que deve ser priorizado pela agência no semestre seguinte, conforme os projetos e serviços indicados para execução, considerando sua viabilidade comercial e financeira e sua exequibilidade técnica. 
Há parcerias com outras empresas juniores para o compartilhamento de conhecimentos, principalmente por meio do Núcleo de Empresas Juniores de Bauru (Nejub). A agência também se encontra na fase final de filiação à FEJESP, a maior federação de empresas juniores do estado de São Paulo. A prospecção de novos parceiros e clientes é uma ação constante.

\section{Visão dos estudantes sobre empreendedorismo na graduação}

Com o objetivo de suscitar uma reflexão sobre a contribuição oferecida pelo projeto de extensão da Agência Júnior de Jornalismo para a formação dos estudantes e, especialmente, a articulação que se dá em torno dos temas associados ao empreendorismo e sua inserção no campo profissional, foi realizada em janeiro de 2015 uma pesquisa que combinou técnicas qualitativas e quantitativas de coleta e análise de dados com a participação voluntária de 22 ex-alunos colaboradores da agência. Esses estudantes foram convidados a avaliar e comentar, por meio de um questionário on-line, a importância conferida a assuntos de empreendedorismo no programa do curso, o relacionamento entre a universidade e agentes do campo profissional e a contribuição pedagógica extraída de uma série de atividades aplicadas propostas em torno do projeto. Todos responderam a sete questões de múltipla escolha com respostas padronizadas de acordo com a escala Likert. Doze dos 22 participantes forneceram também comentários verbais sobre os tópicos levantados. Os resultados são descritos a seguir.

\section{a) Importância do empreendedorismo}

Todos os consultados consideraram importante (45\%) ou muito importante (55\%) a inserção de temas e atividades ligadas ao empreendedorismo na formação profissional de jornalistas. As opções de resposta que atribuíam à questão uma importância de nível médio, pequeno ou nula não foram assinaladas. 
A visão que ampara essa percepção pode ser sintetizada em seis argumentos centrais, extraídos do exame dos depoimentos coletados a esse respeito. Para eles, a inserção do empreendedorismo na formação de jornalistas deve ser buscada de modo que o egresso do curso de graduação possa: 1) compreender como produtos jornalísticos são comercializados e distribuídos no mercado para além de seus processos de produção; 2) experimentar e vivenciar aspectos práticos da atuação profissional em jornalismo diante da insuficiência das vagas de estágio no setor; 3) acompanhar as transformações em curso nesse mercado, preparando-se para um ambiente profissional competitivo e em rápida evolução; 4) adquirir subsídios técnicos que os auxiliem no desenvolvimento e na gestão de seus próprios negócios, gerando valor a partir de sua aplicação profissional; 5) ampliar os conhecimentos adquiridos ao longo do curso para além das disciplinas que tradicionalmente integram sua base curricular; e 6) ter uma "porta de entrada" para sua atuação no mercado de trabalho, ampliando sua rede de contatos, visibilidade profissional e as chances de obter um bom emprego.

\section{b) Contribuição da agência Jornal Jr.}

Dos alunos consultados, 68\% consideram muito importante a contribuição oferecida pela Agência Júnior de Jornalismo para a formação profissional oferecida pelo curso de graduação da Unesp. Outros 27\% acreditam que essa contribuição foi importante em seu processo de aprendizado e uma minoria de 4\% considerou-a apenas mediana. As opções pouco importante e nada importante não foram assinaladas. A esse respeito, os estudantes comentaram o seguinte:

Dentro da Jornal Jr., adquiri visão empresarial, aprendi a vender e valorizar o trabalho de jornalista. Lidei com temas que não são apresentados na grade curricular, tive experiências únicas para a minha formação (Aluno 1).

Sem ela [Jornal Jr.], talvez eu não tivesse noções de marketing, planejamento, empreendedorismo e recursos humanos como tenho hoje (Aluno 2). 
A agência foi importante para a minha entrada no mercado de trabalho, principalmente pela experiência adquirida no trabalho em grupo e no planejamento de eventos (Aluno 4).

A Agência Junior de Jornalismo me auxiliou a observar o jornalismo de uma outra maneira: comercial e empreendedora. Para o mercado de trabalho, é importante que eu tenha desenvolvido essa visão (Aluno 6).

A Jornal Jr. me trouxe um leque enorme de contatos e reconhecimento. Contatos estes que utilizo até hoje já no mercado de trabalho. Além disso, as experiências vivenciadas na Jornal contribuíram para o meu crescimento profissional (Aluno 8).

O trabalho na Jornal Júnior ampliou minha visão de jornalismo. O curso peca em direcionar a visão praticamente para a reportagem apenas, enquanto a Jornal Jr. é uma experiência em gerir negócios jornalísticos, desenvolver estratégias e aproximação do mercado (Aluno 10).

\section{c) Inserção do empreendedorismo no curso}

Nenhum dos alunos consultados considerou como sendo grande ou plena a inserção de temas ligadas ao empreendedorismo no curso de jornalismo da Unesp. Para 22\% dos consultados, houve alguma inserção; 59\% avaliam que houve pouca inserção; outros $18 \%$ afirmaram não ter havido qualquer presença do tema ao longo do curso (excluindo-se o âmbito do próprio projeto de extensão). A percepção crítica dessa insuficiência em relação ao curso fica nítida a partir da leitura de alguns depoimentos colhidos:

A questão do empreendedorismo não é trabalhada em nenhum momento da grade curricular do curso, o que prejudica o futuro formando quando ele estiver no mercado de trabalho (Aluno 1).

Os estudantes saem da Unesp despreparados para ingressar no mercado - e até mesmo se aventurar em potenciais campos a serem explorados. [...] Não temos qualquer tipo de suporte - teórico ou prático - para empreender um eventual negócio próprio (Aluno 3). 
Normalmente, o que nos é ensinado é que seremos repórteres e os donos dos jornais são os empreendedores. Nos falta a magnitude do empreendedorismo dentro da comunicação e de como é possível unir os dois (Aluno 6).

Pude compreender processos internos à universidade, além de ter crescido profissionalmente, já que o projeto de extensão supre lacunas verificadas na graduação (Aluno 7).

Nas aulas, não temos muitas referências sobre o assunto e tudo que sei sobre [empreendedorismo] aprendi na empresa júnior (Aluno 9).

Não há essa cultura no curso. Por mais que haja intenções por parte de alguns professores e alunos, o espírito do curso ainda é muito fechado a temas voltados ao empreendedorismo e ao mercado de trabalho. Se a grade do curso passasse a ter mais ligação com esses temas, acredito que os próprios alunos mudariam suas concepções (Aluno 10).

A Unesp ainda engatinha nas discussões acerca do empreendedorismo no jornalismo. As experiências nesse aspecto só podem ser vivenciadas a partir de projetos de extensão e pesquisa (Aluno 11).

Apesar dessas críticas, $18 \%$ dos alunos consultados consideram ter havido grande articulação e 6\%, alguma articulação entre teorias e práticas de empreendedorismo na interface entre a Jornal Jr. e disciplinas curriculares do curso de jornalismo da Unesp. Nos comentários a esse respeito, porém, boa parte dos estudantes atribui tal articulação à interação mantida, em sala de aula, entre os próprios membros da Agência Junior de Jornalismo, ao trazerem para o debate com professores e colegas de classe questões relacionadas às práticas profissionais vivenciadas em torno do projeto de extensão. Ainda assim, 36\% dos alunos consultados dimensionam como pouca essa articulação e $9 \%$ a identificaram como inexistente, posições que se destacam também nos comentários coletados a esse respeito:

Acredito que, nesse sentido, a teoria está bastante distante da prática. O que se lê nos livros não é bem o que ocorre no contexto da Jornal (Aluno 8). 
A experiência na Jornal Jr. mostra que a realidade do mercado de trabalho e da própria sociedade nem sempre é parecido com o que é idealizado nas salas de aulas. Muitas matérias foram aplicadas na prática pelos membros da Jornal Jr., mas muita coisa tivemos que descobrir sozinhos e até mesmo procurar outras fontes de formação (Aluno 10).

A grade curricular da Unesp ainda não permite que haja espaços "abertos" para discussões sobre empreendedorismo. Tampouco os professores parecem apresentar interesse em explorar essa área (Aluno 11).

Tudo que se faz na Jornal em relação a mercado é feito através de pesquisas e articulação com especialistas. Do curso, pouco se usa (Aluno 12).

\section{d) Relação entre universidade e campo profissional}

Quando questionados acerca da importância do relacionamento entre a universidade e empresas e agentes econômicos externos ligados ao campo profissional, 59\% dos respondentes da pesquisa consideraram que se trata de algo muito importante e $31 \%$ veem tal relação como importante. Não houve registro nas opções mediana e pouco importante. Dois alunos consultados, ou 9\% da amostra, avaliaram esse tipo de relacionamento paradidático como sendo nada importante. Alguns dos respondentes que comentaram a questão consideram essa aproximação não apenas importante, mas até "essencial" e "imprescindível" na formação em jornalismo, com vistas, sobretudo, à inserção no mercado de trabalho. Também alertam, contudo, para a necessidade de manter-se a independência e a autonomia da universidade em relação a interesses específicos das empresas. Destacam-se, neste sentido, as seguintes afirmações:

Se não conhecermos o mercado, não saberemos depois de formados como nos inserir nele. Muitos dizem que o mercado para jornalistas está saturado, mas talvez esteja para aqueles que não se prepararam suficientemente (Aluno 3). 
Em relação ao que se diz da parte financeira, sou contra que haja articulação com agentes externos. Eu sou da ideia de que deve haver verba, claro, porém provinda da própria universidade. A ação desses agentes econômicos externos, na minha opinião, não é ética, afinal, estamos em uma universidade pública (Aluno 6).

É dever de empresas e instituições, privadas ou não, investir nas universidades, uma vez que os profissionais que serão formados trabalharão no futuro para essas empresas. [...] O discurso de que não devem existir parcerias estreitas entre universidade e agentes econômicos é falho nesse sentido. Ainda mais com o argumento de que a universidade deve exercer sua missão social, pois um jornalista bem preparado e formado será sem dúvida um bom investimento para a sociedade. E também as parcerias não excluem outras inúmeras formas de atuações da universidade (Aluno 10).

Avalio como imprescindível, sobretudo atualmente, o diálogo e interação entre empresas jornalísticas, agentes econômicos e universidade. A solidificação e consolidação de parcerias, projetos e adjacentes permitem que, principalmente em tempos de crise, lacunas sejam preenchidas, o aluno apresente maior repertório quando for necessário inserir-se no mercado de trabalho, além de servirem como gancho para eventuais estágios. Contudo, avalio negativamente as propostas e parcerias que visam inserir a submissão do público ao privado. A interação é necessária, mas submeter-se e depender das chamadas PPPs é um erro (Aluno 11).

Quando consideradas as oportunidades de aproximação com os agentes do mercado de trabalho oferecidas a partir do curso de jornalismo da Unesp, nenhum aluno consultado julgou haver plena interação e apenas um deles (4\%) assinalou a existência de grande interação nesse sentido. Para 31\%, houve alguma interação; para $45 \%$, houve pouca interação; e para $18 \%$, não houve interação alguma. Em depoimentos, indicou-se o seguinte:

Esta questão é de extrema importância, mas bastante limitada na Unesp. Talvez por ser no interior, considero as possibilidades de parcerias mais escassas no segmento da comunicação e, consequen- 
temente, do jornalismo. Ao contrário do que ocorre em universidades de São Paulo, por exemplo, são poucos os alunos da Unesp que realizam estágios durante a graduação. $\mathrm{Na}$ minha visão, isso prejudica bastante a formação. $\mathrm{O}$ volume de profissionais lançados no mercado anualmente é grande demais para as necessidades das próprias empresas do ramo em Bauru e região (Aluno 3).

\section{e) Avaliação das atividades aplicadas desenvolvidas}

A pesquisa também coletou dados acerca da importância atribuída pelos ex-alunos a uma série de atividades aplicadas em torno do projeto de extensão da Agência Junior de Jornalismo. Foi solicitado a cada um dos respondentes que indicasse um valor, numa escala de 1 a 5 , considerando o quanto essas atividades contribuíram para sua formação profissional.

Foram avaliados a participação em projetos da empresa júnior, a participação na gestão da empresa júnior, visitas técnicas a grandes empresas jornalística, visitas técnicas a pequenas empresas jornalística, workshops e oficinas com profissionais da área, estágios de longa duração em empresa jornalística, estágios de curta duração em empresa jornalística, participação em feiras e exposições comerciais, planejamento e desenvolvimento de produtos jornalísticos, análise e desenvolvimento de modelos de negócios, análise e desenvolvimento de planos detalhados de negócio, publicação e distribuição de produtos jornalísticos, contato com clientes e fornecedores de serviços, elaboração de orçamentos para projetos jornalísticos, acompanhamento de rotinas de compra e cotação de preços, realização de pesquisas de mercado com atividades de campo, realização de pesquisas de mercado pela internet e leitura de relatórios, balanços e anuários de resultados das empresas jornalísticas.

O resultado desse levantamento pode ser conferido na Tabela 1, a seguir, que elenca essas atividades conforme o grau de importância que lhes foi atribuído pelos alunos consultados. A lista de atividades correspondentes às linhas da tabela foi organizada em ordem decrescente de importância, a partir do maior número de respostas que consideram a atividade como sendo muito importante. 
Tabela 1. Grau de importância atribuído por ex-alunos a atividades de formação

\begin{tabular}{|c|c|c|c|c|c|c|}
\hline \multirow{2}{*}{\multicolumn{2}{|c|}{ Atividade }} & \multicolumn{5}{|c|}{ Grau de importância } \\
\hline & & \multicolumn{3}{|c|}{ (-) Menor } & \multicolumn{2}{|c|}{ Maior (+) } \\
\hline 1 & $\begin{array}{l}\text { Planejamento e desenvolvimento de } \\
\text { produtos }\end{array}$ & & & 1 & 1 & 20 \\
\hline 2 & $\begin{array}{l}\text { Participação em projetos da empresa } \\
\text { júnior }\end{array}$ & & & 1 & 5 & 16 \\
\hline 3 & $\begin{array}{l}\text { Publicação e distribuição de produtos } \\
\text { jornalísticos }\end{array}$ & & & 1 & 5 & 16 \\
\hline 4 & $\begin{array}{l}\text { Participação na gestão da empresa } \\
\text { júnior }\end{array}$ & & & 1 & 6 & 15 \\
\hline 5 & $\begin{array}{l}\text { Contato com clientes e fornecedores de } \\
\text { serviços }\end{array}$ & 1 & & 4 & 3 & 14 \\
\hline 6 & $\begin{array}{l}\text { Análise e desenvolvimento de modelos } \\
\text { de negócio }\end{array}$ & & & 2 & 6 & 14 \\
\hline 7 & $\begin{array}{l}\text { Pesquisas de mercado com atividades } \\
\text { de campo }\end{array}$ & & & 3 & 6 & 13 \\
\hline 8 & $\begin{array}{l}\text { Estágios de curta duração em empresa } \\
\text { jornalística }\end{array}$ & & & 2 & 8 & 12 \\
\hline 9 & $\begin{array}{l}\text { Workshops e oficinas com profissionais } \\
\text { da área }\end{array}$ & & & 3 & 7 & 12 \\
\hline 10 & $\begin{array}{l}\text { Visitas técnicas a grandes empresas } \\
\text { jornalísticas }\end{array}$ & & & 5 & 6 & 11 \\
\hline 11 & $\begin{array}{l}\text { Realização de pesquisas de mercado } \\
\text { pela internet }\end{array}$ & & & 5 & 6 & 11 \\
\hline 12 & $\begin{array}{l}\text { Visitas técnicas a pequenas empresas } \\
\text { jornalísticas }\end{array}$ & & & 6 & 5 & 11 \\
\hline 13 & $\begin{array}{l}\text { Participação em feiras e exposições } \\
\text { comerciais }\end{array}$ & 1 & 1 & 2 & 8 & 10 \\
\hline 14 & $\begin{array}{l}\text { Elaboração de orçamentos para projetos } \\
\text { jornalísticos }\end{array}$ & & & 3 & 9 & 10 \\
\hline 15 & $\begin{array}{l}\text { Análise e desenvolvimento de planos } \\
\text { detalhados de negócio }\end{array}$ & & 1 & 3 & 8 & 10 \\
\hline 16 & $\begin{array}{l}\text { Estágios de longa duração em empresas } \\
\text { jornalísticas }\end{array}$ & & & 3 & 9 & 10 \\
\hline 17 & $\begin{array}{l}\text { Acompanhamento de rotinas de } \\
\text { compra e cotação de preços }\end{array}$ & & 2 & 8 & 6 & 6 \\
\hline 18 & $\begin{array}{l}\text { Leitura de relatórios, balanços e } \\
\text { anuários de empresas }\end{array}$ & & 1 & 7 & 9 & 5 \\
\hline
\end{tabular}


De modo geral, todas as atividades elencadas foram consideradas como algo importante, e dezesseis delas tiveram ao menos dez indicações, dentre 22 possíveis, como sendo muito importantes. As quatro mais citadas neste grau foram, pela ordem, as de planejamento e desenvolvimento de produtos, participação em projetos da empresa júnior, publicação e distribuição de produtos jornalísticos e participação na gestão da empresa júnior. As duas menos citadas foram acompanhamento de rotinas de compra e cotação de preços e leitura de relatórios, balanços e anuários de resultados de empresas jornalísticas.

\section{Considerações finais}

O âmbito da extensão universitária, previsto no artigo 207 da Constituição Federal do Brasil, é tradicionalmente reconhecido por sua missão de aproximar instituições de ensino superior de demandas sociais e comunitárias motivadoras de interesse público e acadêmico, levando estudantes, professores, técnicos e outros grupos envolvidos nesses projetos a aplicarem conhecimentos produzidos e difundidos em seus programas de ensino e pesquisa na resolução de problemas concretos da sociedade.

Mais do que prestar assistência a esses segmentos sociais, o propósito da extensão é gerar consigo um novo ciclo de produção de conhecimentos, na medida em que estes se articulam, então, com um conjunto mais amplo e diversificado de saberes, num processo retroativo que também insemina e influencia a agenda dos programas de ensino e pesquisa.

Não se trata, portanto, de um tripé com extremidades estáticas a pesquisa, o ensino e a extensão -, mas de seções interconectadas de uma espiral contínua de produção, difusão, aplicação e revisão do conhecimento, mesclando teoria e prática, reflexão e ação, técnica e ética, experiência e conceituação. E é isso o que, em seus limites, uma agência ou empresa júnior podem fazer ao assumirem seu papel único entre os programas de extensão, aproximando as dimensões do saber e do fazer que compõem o aprendizado na graduação. 
Por isso mesmo, as atividades extensionistas nas universidades constituem um espaço de formação privilegiado para o desenvolvimento de atividades capazes de levar estudantes a vivenciarem, ainda que parcialmente e dentro de certos limites pedagógicos, uma série de desafios próprios do campo profissional no qual almejam atuar, e também empreender.

Não raramente, é na extensão que estudantes experimentam, pela primeira vez, sua capacidade de transpor as competências e habilidades apreendidas nas salas de aula e nos laboratórios didáticos para seus contextos reais de aplicação, lidando com agentes externos à universidade e vivenciando, ainda que muitas vezes apenas indiretamente, os conflitos e contradições que permeiam tal relação.

Nessa perspectiva, projetos extensionistas caracterizados como agências ou empresas juniores de comunicação constituem um instrumento especialmente capaz de catalisar essas experiências e sistematizar uma aproximação em benefício mútuo das comunidades internas (estudantes, professores) e externas (empresas, associações, órgãos de governo e, indiretamente, seus próprios públicos internos e externos).

Por meio de uma lógica que não é somente educativa, mas também organizacional, administrativa e comercial, esses projetos de extensão com foco no empreendedorismo contribuem de modo ímpar para introduzir, na formação universitária, espaços que funcionem como campo de prova para a prestação de serviços efetivos, capazes de atender a demandas de agentes sociais e econômicos que tenham propósitos aderentes à missão universitária, e com isso também permitir aos alunos que se projetem, influenciem e insiram-se, gradualmente, na realidade de seu campo profissional.

\section{Referências bibliográficas}

BRIGGS, M. Entrepreneurial Journalism. Los Angeles: Sage, 2012.

GROHMANN, R. Os discursos dos jornalistas freelancers sobre o trabalho: comunicação, mediações e recepção. 273f. Dissertação. (Mestrado em Ciências da Comunicação). São Paulo: ECA-USP, 2012. 
MATOS, F. A. Empresa Júnior no Brasil e no Mundo. São Paulo: Martin Claret, 1997.

RIBEIRO, M. C. Depois das primeiras impressões. Revista Página 22, n.76, 2013, p.49. Disponível em: http://bibliotecadigital.fgv.br/ojs/ index.php/pagina22/article/view/28645/27506. Acesso em: 15 jan. 2015.

ROXO, M., GROHMANN, R. Sentidos do empreendedorismo no campo profissional jornalístico. Anais do Congresso Internacional Comunicação e Consumo 2014. São Paulo: ESPM, 2014.

TORRES, C. C. Jornalistas devem ser jornalistas. E empreendedores. Observatório da Imprensa, edição 691, publicado em 24 abril de 2012. Disponível em: http://www.observatoriodaimprensa.com.br/news/ view/_ed691_jornalistas_devem_ser_jornalistas_e_empreendedores. Acesso em: 15 jan. 2015. 


\section{SOBRE OS AUTORES}

Eliza Bachega Casadei. Doutora em Ciências da Comunicação pela Escola de Comunicações e Artes da Universidade de São Paulo (ECA-USP), mestra em Ciências da Comunicação e bacharel em Comunicação Social com habilitação em Jornalismo pela mesma instituição. É professora de fotojornalismo da graduação em Jornalismo e da pós-graduação em Comunicação da Faculdade de Arquitetura, Artes e Comunicação da Universidade Estadual Paulista "Júlio de Mesquita Filho" (FAAC-Unesp).

Mariana Duccini Junqueira da Silva. Mestra e doutora em Ciências da Comunicação pela ECA-USP. Jornalista pela Faculdade de Arquitetura, Artes e Comunicação da Universidade Estadual Paulista "Júlio de Mesquita Filho" (FAAC-Unesp). Professora do Insper - Instituto de Ensino e Pesquisa.

Paulo Roberto Figueira Leal. Graduado em Jornalismo pela Universidade Federal do Rio de Janeiro (1991), com mestrado em Ciência Política (Ciência Política e Sociologia) pelo Iuperj (1997) e doutorado em Ciência Política (Ciência Política e Sociologia) pelo Iuperj (2003). Professor associado da Universidade Federal de Juiz de Fora, lecionando na graduação e no mestrado em Comunicação da Facom-UFJF. 
Rafael do Nascimento Grohmann. Mestre e doutorando em Ciências da Comunicação da Universidade de São Paulo (USP). Professor dos cursos de Comunicação Social do FIAM-FAAM Centro Universitário e da Faculdade Cásper Líbero. Pesquisador do Centro de Pesquisas em Comunicação e Trabalho (CPCT-ECA/USP-CNPq). Possui graduação (bacharelado/ licenciatura) em Ciências Sociais pela Universidade Federal de Juiz de Fora (UFJF), concluída em 2009.

Rodrigo Souza Silva. Graduado em Comunicação pela Universidade Federal de Juiz de Fora (UFJF).

Juarez Tadeu de Paula Xavier. Coordenador do Núcleo de Estudos e Observação em Economia Criativa (NeoCriativa); docente do Departamento de Comunicação Social da Faculdade de Arquitetura, Artes e Comunicação da Universidade Estadual Paulista (DCSO/FAAC/Unesp) Júlio de Mesquita Filho, nas disciplinas Jornalismo Especializado I e II; pesquisador do Laboratório de Estudo em Comunicação, Tecnologia e Educação Cidadã (Lecotec); professor colaborador do Programa de Pós-Graduação em Televisão Digital: Informação e Conhecimento.

Marcos Américo. Docente do Departamento de Comunicação Social e do Programa de Pós-graduação em Televisão Digital: Informação e Conhecimento, da Unesp. Líder do Grupo de Estudo em Comunicação Esportiva e Futebol (Gecef).

José Carlos Marques. Docente do Departamento de Ciências Humanas e do Programa de Pós-graduação em Comunicação da Unesp. Líder do Grupo de Estudo em Comunicação Esportiva e Futebol (Gecef).

Carlo José Napolitano. Docente do Departamento de Ciências Humanas e do Programa de Pós-graduação em Comunicação da Unesp. Pesquisador do Grupo de Estudo em Comunicação Esportiva e Futebol (Gecef).

Fábio Camargo Fleury de Oliveira. Mestre em Comunicação pelo Programa de Pós-graduação em Comunicação da Unesp. 
Programador da Rádio Unesp FM. Pesquisador do Grupo de Estudo em Comunicação Esportiva e Futebol (Gecef).

Letícia Passos Affini. Graduada em Comunicação Social com habilitação em Radialismo pela Universidade Estadual Paulista "Júlio de Mesquita Filho" (Unesp) (1992), mestra em Comunicação e Semiótica pela Pontifícia Universidade Católica (PUC) de São Paulo (1997) e doutora em Comunicação e Cultura pela Universidade Federal do Rio de Janeiro (UFRJ) (2003). Atualmente é professora assistente doutora da Unesp. Pesquisadora líder no Grupo de Análise do Audiovisual (GrAAu), cadastrado no CNPq.

Luis Enrique Cazani Júnior. Graduado em Comunicação Social com habilitação em Radialismo pela Universidade Estadual Paulista "Júlio de Mesquita Filho", Faculdade de Arquitetura, Artes e Comunicação (FAAC/Unesp).

Francisco Machado Filho. Professor do curso de Jornalismo da Universidade Estadual Paulista "Júlio de Mesquita Filho" (Unesp). Doutor em Comunicação pela Universidade Metodista de São Paulo.

Mayra Fernanda Ferreira. Doutoranda em Comunicação da Universidade Estadual Paulista "Júlio de Mesquita Filho" (Unesp). Professora da Universidade Sagrado Coração. Jornalista da TV Universitária Unesp.

Francisco Rolfsen Belda. Professor doutor do Departamento de Comunicação Social, FAAC/Unesp, Bauru. 


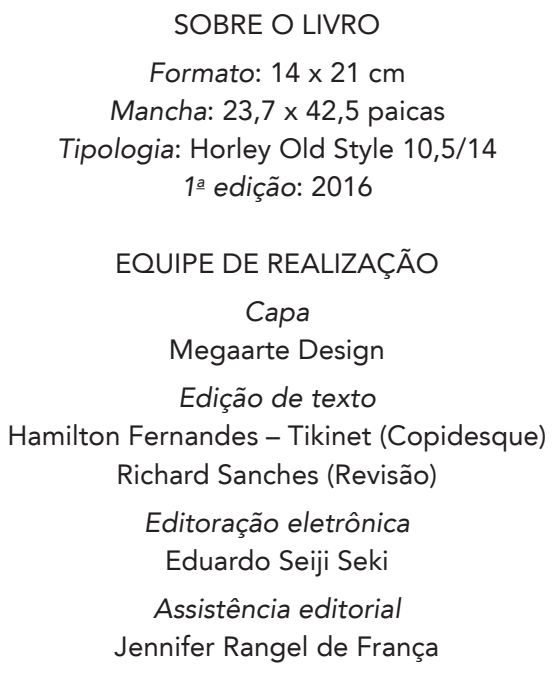

Formato: $14 \times 21 \mathrm{~cm}$

Mancha: $23,7 \times 42,5$ paicas

Tipologia: Horley Old Style 10,5/14

1̄a edição: 2016

EQUIPE DE REALIZAÇÃO

Capa

Megaarte Design

Edição de texto

Hamilton Fernandes - Tikinet (Copidesque)

Richard Sanches (Revisão)

Editoração eletrônica

Eduardo Seiji Seki

Assistência editorial

Jennifer Rangel de França 